\title{
Column Flotation of Subbituminous Coal Using the Blend of Trimethyl Pentanediol Derivatives and Pico-Nano Bubbles
}

Jinxiang Chen

West Virginia University

Follow this and additional works at: https://researchrepository.wvu.edu/etd

\section{Recommended Citation}

Chen, Jinxiang, "Column Flotation of Subbituminous Coal Using the Blend of Trimethyl Pentanediol Derivatives and Pico-Nano Bubbles" (2013). Graduate Theses, Dissertations, and Problem Reports. 3384. https://researchrepository.wvu.edu/etd/3384

This Thesis is protected by copyright and/or related rights. It has been brought to you by the The Research Repository @ WVU with permission from the rights-holder(s). You are free to use this Thesis in any way that is permitted by the copyright and related rights legislation that applies to your use. For other uses you must obtain permission from the rights-holder(s) directly, unless additional rights are indicated by a Creative Commons license in the record and/ or on the work itself. This Thesis has been accepted for inclusion in WVU Graduate Theses, Dissertations, and Problem Reports collection by an authorized administrator of The Research Repository @ WVU. For more information, please contact researchrepository@mail.wvu.edu. 


\title{
Column Flotation of Subbituminous Coal Using the Blend of Trimethyl
} Pentanediol Derivatives and Pico-Nano Bubbles

\author{
Jinxiang Chen
}

Thesis submitted to

the Benjamin M. Statler College of Engineering and Mineral Resources at West Virginia University in Partial Fulfillment of the Requirements for the Degree of

\author{
Master of Science \\ in \\ Mining Engineering \\ Felicia F. Peng, Ph.D., Chair \\ Yi Luo, Ph.D. \\ Roger Chen, Ph.D. \\ Department of Mining Engineering
}

Morgantown, West Virginia

2013

Keywords: Subbituminous Coal, Low Rank Coal, Semi-batch Cell Flotation, Column Flotation, Pico and Nano Bubbles, Trimethyl Pentanediol Derivatives 


\title{
ABSTRACT \\ Column Flotation of Subbituminous Coal Using the Blend of Trimethyl Pentanediol Derivatives and Pico-Nano Bubbles
}

\author{
Jinxiang Chen
}

Subbituminous coal, a low rank of coal, is difficult-to-float using the conventional flotation process by a single frother such as MIBC and a single collector such as kerosene or fuel oil. The froth flotation of the fine coal separation process is based on the differences of wettability between coal and mineral particles. The formation of oxygenated functional groups on coal surface can reduce its hydrophobicity. This result makes the coal more difficult to float by oily collector alone. Previous work shows that the surfactant can be used to activate the oxygenated surface, by selecting the group of such as fatty acids, trimethyl pentanediol derivatives, hydroxylated ether amine, etc. In the present study, the blend of trimethyl pentanediol derivatives as frother and kerosene as collector are used in column flotation of subbituminous coal. The frother made of trimethyl pentanediol derivatives provides better spreading of oily collector, froth stability, and selectivity.

The flotation column used is equipped with a static-mixer and a venturi cavitation tube for pico and nano bubble generation, and a double funnel tailings separator. Three stages of statistical design of experiment of column flotation are conducted to optimize operation conditions. The results show that $96.87 \%$ of combustible material recovery and $13.13 \%$ of clean coal ash content are obtained. The effect of pico and nano bubbles is to increase the recovery of low rank coal. Furthermore, clean coal with the combustible material recovery of $81.2 \%$ and ash content of $9.1 \%$, by desliming minus $45 \mu \mathrm{m}$ size fraction particles of feed coal before column flotation are also achieved. 


\section{ACKNOWLEDGEMENT}

I would like to express my great thankfulness to my graduate advisor Dr. Felicia F. Peng for her guidance, advice and encouragement during my study in West Virginia University. Her propositions for my research activities act an important role for my academic development. Her attitude and diligence toward work has greatly influenced me and directly lead to the success of my academic and my personal development. I also would like to express my gratitude to Dr. Yi Luo from the Department of Mining Engineering and Dr. Roger Chen from the Department from Civil and Environmental Engineering of West Virginia University for their advice and recommendations for my research.

I also would like to give my deepest appreciation to all the graduate students in Mining Engineering for their friendship. This work is performed under a project sponsored by the West Virginia State Energy and Coal Research Bureau. Their financial support is gratefully acknowledged.

Finally, I would like to express my greatest appreciation to my family whose love, encouragement and support help me achieve my final success. 


\section{TABLE OF CONTENTS}

\section{Page}

ABSTRACT .II

ACKNOWLEDGEMENT III

TABLE OF CONTENTS IV

LIST OF TABLES $\mathrm{VI}$

LIST OF FIGURES .VIII

CHAPTER 1 .... .1

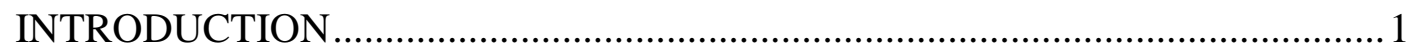

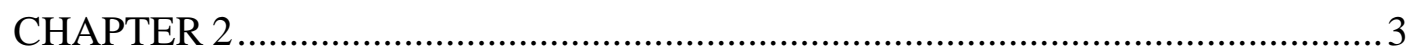

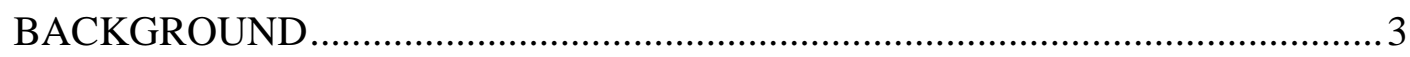

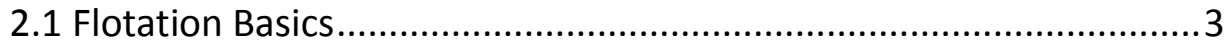

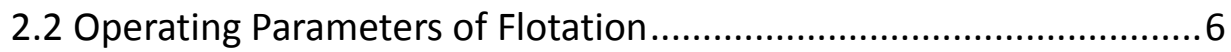

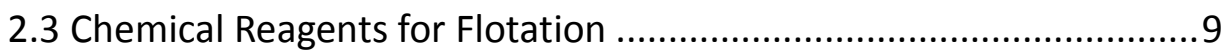

2.4 Properties of Oxidized Coal .........................................................10

2.5 Reagents for Flotation of Difficult-to-Float Coal/Oxidized Coal.......11

2.6 Use of Polyglycol Ether as Frother..............................................13

2.7 Foamability of Frothers ......................................................... 15

2.8 Methods to Improve the Flotation of Difficult-to-Float Coal ...........16

2.9 Pico and Nano Bubble Venturi Cavitation Tube for Column Flotation 


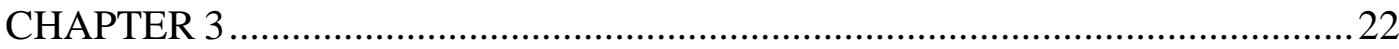

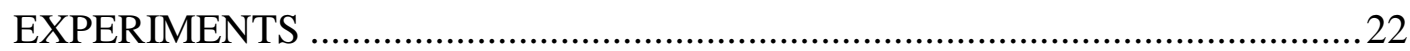

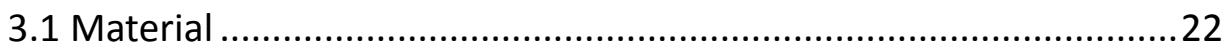

3.2 Experiment Procedures ..........................................................24

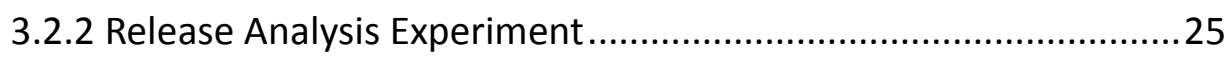

3.2.3 Column Flotation Experiments ...............................................27

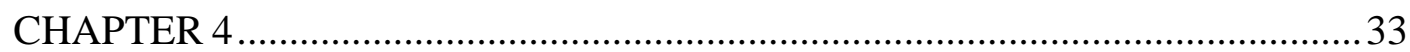

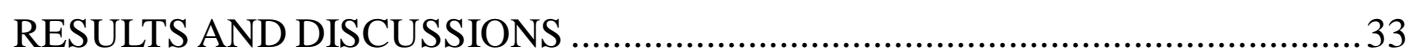

4.1 Particle Size Distribution ............................................................33

4.2 Flotation Rate of Stirred Tank Cell ....................................................34

4.3 Frother and Collector Effects for Stirred Tank Cell Flotation.............39

4.4 Column Flotation Using Pico and Nano Bubbles ...........................46

4.5 Effect of Ultrafine Mineral Particles on Flotation ............................73

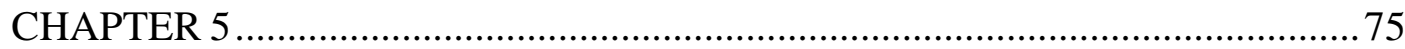

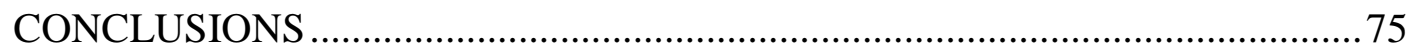

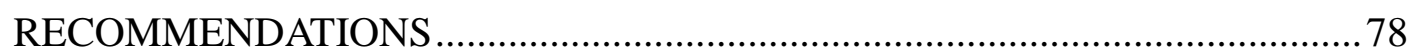

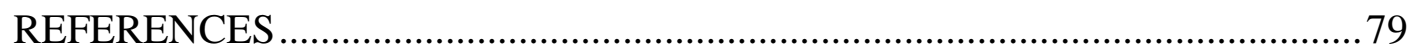

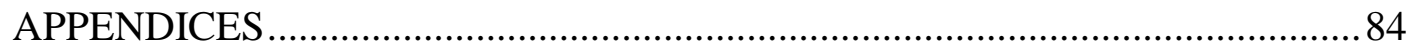




\section{LIST OF TABLES}

Page

Table 3-1 Proximate analysis of the fine feed

Table 3-2 Operation conditions of stirred tank cell flotation ...................................25

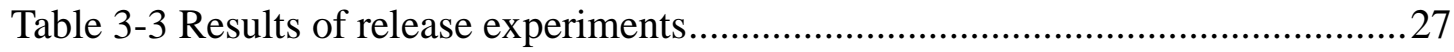

Table 3-4 Operation conditions of flotation column ....................................................

Table 4-1 Particle size distribution and ash content of ultrafine feed coal. .................33

Table 4-2 Flotation rate results using collector of $0.5 \mathrm{~kg} / \mathrm{mt}$ and frother of $0.02 \mathrm{~kg} / \mathrm{mt}$

Table 4-3 Flotation rate results using collector of $2 \mathrm{~kg} / \mathrm{mt}$ and frother of $0.3 \mathrm{~kg} / \mathrm{mt} \ldots 36$

Table 4-4 Results of stirred tank cell flotation using various MIBC dosages at 0.5

$\mathrm{kg} / \mathrm{mt}$ kerosene . .40

Table 4-5 Results of stirred tank cell flotation using various TTT frother dosages at

$0.5 \mathrm{~kg} / \mathrm{mt}$ kerosene

Table 4-6 Results of stirred tank cell flotation using kerosene as variable. 45

Table 4-7 Fractional factorial design of experiment for column flotation tests using 6 factors 50

Table 4-8 Ranges of three levels for the first stage design of experiment using 6 factors

Table 4-9 Analysis of Variance table for the first stage design of experiment. 52

Table 4-10 Effect Tests table for the first stage design of experiment 52

Table 4-11 Effect Tests table of the combinations of each two factors for the first stage design of experiment 59

Table 4-12 Explanations for the factors in interaction 59

Table 4-13 Second stage of design of experiments using 3 factors 60 
Table 4-14 Ranges of three levels for the second stage design of experiment using three factors. .60

Table 4-15 Analysis of Variance table for the second stage of design of experiment..62 Table 4-16 Effect Tests table of the second stage of design of experiment .62

Table 4-17 Third stage design of experiments 68

Table 4-18 Column Flotation Test on Feed Coal after Desliming minus $45 \mu \mathrm{m}$ particles. .74

Table A-1 Results of first stage of experiments 85

Table A-2 Results of the second stage design of experiments 87

Table A-3 Results of the third stage of experiments 88 


\section{LIST OF FIGURES}

Page

Figure 2-1 Schematic representation of the air-solid contact in the three phase system.

Figure 2-2 Schematic diagram of a stirred tank flotation flotation cell (Koh and

Schwarz, 2007) 7

Figure 2-3 Schematic diagram of the microbubble flotation cell (Cowburn et al., 2006). 8

Figure 2-4 Schematic diagram of the Jameson flotation cell (Lahey et al., 1998)........8

Figure 2-5 Structure of THF series (Jia et al., 2000)............................................... 12

Figure 3-1 Schematic diagram of the crushing treatment for the raw coal................23

Figure 3-2 Schematic diagram of the release experiments. ....................................26

Figure 3-3 Schematic diagram of flotation column system.....................................31

Figure 4-1 Weight and ash percent of the feed coal...................................................33

Figure 4-2 Combustible material recovery as a function of time (a) collector $0.5 \mathrm{~kg} / \mathrm{mt}$, frother $0.02 \mathrm{~kg} / \mathrm{mt}$ (b) and collector $2 \mathrm{~kg} / \mathrm{mt}$, frother $0.3 \mathrm{~kg} / \mathrm{mt}$. 37

Figure 4-3 Combustible material recovery versus ash content (a) collector $0.5 \mathrm{~kg} / \mathrm{mt}$, frother $0.02 \mathrm{~kg} / \mathrm{mt}$, and (b) collector $2 \mathrm{~kg} / \mathrm{mt}$, frother $0.3 \mathrm{~kg} / \mathrm{mt}$. 38

Figure 4-4 Combustible material recovery and clean coal ash versus MIBC dosage in the stirred tank cell flotation.

Figure 4-5 Combustible material recovery and clean coal ash versus the TTT frother dosage in stirred tank cell flotation. 43

Figure 4-6 Combustible material recovery and clean coal ash versus kerosene dosage 
in stirred tank cell flotation.

Figure 4-7 Effect of feed solid concentration and collector dosage on (a) the combustible material recovery and (b) clean coal ash.

Figure 4-8 Effect of collector dosage and feed rate on (a) the combustible material recovery and (b) clean coal ash. 55

Figure 4-9 Effect of feed rate and feed solid concentration on (a) the combustible material recovery and (b) clean coal ash. 56

Figure 4-10 Effect of feed solid concentration and collector dosage on (a) combustible material recovery and (b) clean coal ash content 64

Figure 4-11 Effect of feed rate and feed solid concentration on the clean coal product ash for subbituminous coal .65 Figure 4-12 Effect of collector dosage and feed rate on the clean coal product ash for subbituminous coal .66

Figure 4-13 Correlation between the collector dosage and combustible material recovery and clean coal ash for subbituminous coal flotation. 68

Figure 4-14 Flotation results of release experiments and the three stage of design of experiments 70 


\section{CHAPTER 1 \\ INTRODUCTION}

Fine coal flotation makes use of the natural hydrophobicity of the carbonaceous matter in coal. To enhance the hydrophobicity of the coal particles, oily collectors, such as diesel fuel oil and kerosene are usually added. For higher-rank coals, the reagent consumption in flotation is low because of the natural hydrophobicity of the coal. However, the oxidized coals or low rank coals are difficult to float with commonly used fuel oil or kerosene and large amounts of collectors are required to achieve satisfactory yields. The low floatability is due to the presence of greater amounts of oxygen content and abundance of hydrophilic surface functional groups on fine coal surface. It was reported that sub-bituminous coals have an average oxygen content of $18 \%$, with carboxylic groups constituting about one third of this amount. Therefore, the amount of adhesion of oil droplets on low rank coals is very small, and the use of oil alone cannot improve fine coal flotation performance.

Oxidation alters both physical and chemical properties of the coal surface and reduces the floatability. The surface oxidation of coal is reflected by decrease in $\mathrm{pH}$ of the coal fine slurry. In fine coal, oxidation by weathering, or coals kept for a long period of time at mine site or during storage and transportation results in the formation of oxygenated functional groups. Carboxyl $(\mathrm{RCOOH})$, phenolic $\left(\mathrm{C}_{6} \mathrm{H}_{5} \mathrm{OH}\right)$ and carbonyl $\left(-\mathrm{C}_{6} \mathrm{H}_{5}\right)$ are the most commonly found functionalities on the coal surface and their concentration can be determined. This reduces the hydrophobicity of the coal surface by increasing the number of site that forms hydrogen bonds with water molecules. The most susceptible linkages to oxidation were found to be the $\alpha-\mathrm{CH}_{2}$ groups to polyaromatics. Mitchell et al., (1995), revealed an interesting point on 
oxidation that blue-light irradiation is also a strong agent to oxidize the vitrinite surfaces. Sarikaya et al., (1995), reported that upon oxidation the flotation yield reduces from $95 \%$ to $24 \%$ for a bituminous coal using alcohol type frother only. The oxidation of the surface makes the coal more difficult to float with oily collectors alone. An oily collector cannot spread on the surface of the coal, adsorption behavior of surfactants on oxidized or low rank coal.

There are two objectives for this study: (1) to select the appropriate surfactant made of trimethyl pentanediol derivatives that can enhance the floatability of subbituminous coal. This is to activate oxidized surface of subbituminous to coal become more hydrophobic. (2) To improve the flotation performance of subbituminous coal for maximizing combustible material recovery with acceptable clean coal quality. To achieve this goal, an improved flotation column with the pico and nano bubble generation system and double funnel tailings separator are used to improve the selective flotation of subbituminous coal. 


\section{CHAPTER 2 \\ BACKGROUND}

\subsection{Flotation Basics}

Froth flotation is a processing technique that separates materials with surface property of hydrophilicity from the material that has hydrophobic surface. In this process, air bubbles come into the feed slurry in the flotation cell, and make contact with the feed. The fine particles with hydrophobicity will be attached to the surface of air bubbles and brought to the froth. The hydrophilic particles will detach from the air bubbles after collision and finally remain in the bottom of the cell. Mining industry first used froth flotation in the early 19th century. Many minerals and coal can be beneficiated using the froth flotation with less cost and good efficiency. The first flotation process that was successfully used in the United States was the film flotation in 1911 by Butte and Superior Copper Company. In Europe, froth flotation was first used in coal cleaning in 1920, and the froth flotation plants for coal preparation were established in Spain and in France and in same year (Lynch et al., 2007). Until 1930, coal preparation plants in United States began to use the froth flotation. From that time, the technique of froth flotation in coal was developed, and now the froth flotation is the most widely used processing method for treating fine coal.

The most effective technique to beneficiate fine coal particles $(-250 \mu \mathrm{m})$ is the froth flotation, which uses air bubbles to float hydrophobic particles. Air bubbles can attach to the hydrophobic particles after collision and attachment and bring them to the froth while the hydrophilic particles are left in the slurry. In this system, the formation three-phase system, air-water-solid system, is the basic requirement for froth flotation. In this system, air bubbles make contact with fine particles and then 
attach the hydrophobic ones to the froth. Young's expression (Equation 2-1) provides the basic thermodynamic equations of the formation of three-phase system in the floatation process.

$$
\gamma_{\mathrm{sv}}=\gamma_{s \mathrm{l}}+\gamma_{l v} \cos \theta
$$

Where, $\gamma_{\mathrm{sv}}, \gamma_{\mathrm{sl}}$, and $\gamma_{\mathrm{lv}}$ are the interfacial tensions of solid-gas, solid-liquid and liquid-gas interfaces, $\theta$ is the contact angle (Figure 2-1).

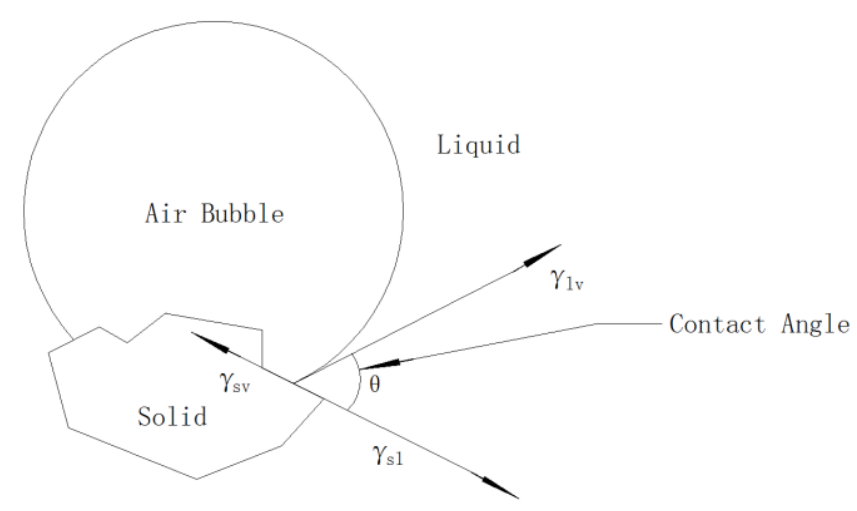

Figure 2-1 Schematic representation of the air-solid contact in the three phase system.

Dupre's equation (Equation 2-2) provides the variation in free energy when the unit area of solid-liquid interface is replaced by the solid-gas interface.

$$
\Delta \mathrm{G}=\gamma_{s v}-\left(\gamma_{s l}+\gamma_{l v}\right)
$$

When the solid-gas interfacial tension is higher than the total amount of solid-liquid and liquid-gas interfacial tensions, the water-solid interface could be changed to solid-gas interface. In addition, combining Young's equation with Dupre's equation, the following expression is derived: 


$$
\Delta G=\gamma_{\mathrm{lv}}(\cos \theta-1)
$$

When the surface property of particles is hydrophobic, its free energy of solid-water-air system can be changed. The principle of contact angle is based on it. If a particle is perfectly hydrophobic, it will have the contact angle of $90^{\circ}$ and its free energy will have the highest negative change.

The kinetic models which treat the flotation procedure as the reaction between air bubbles and particles have attracted the most attention ( Polat, M., Chander, S., 2000). These models have been widely applied for the control strategies in the industry. The general rate expression (Equation 4) for the flotation procedure is given below:

$$
\frac{d C_{p}(t)}{d t}=-k(t) C_{p}^{m}(t) C_{b}^{n}(t)
$$

Where $C_{p}(t)$ and $C_{b}(t)$ are the concentrations of particles and air bubbles at time t. The exponents, $\mathrm{m}$ and $\mathrm{n}$ are the respective orders for particles and air bubbles, and $\mathrm{d}(\mathrm{t})$ is a pseudo rate constant which may vary with time depending on various parameters governing the flotation process. Froth flotation can reach its highest efficiency when the coal particles are in the size range between 10-100 $\mu \mathrm{m}$ (Tao, 2005). The reason for the poor recovery for the coarse particles is because of the high probability of detachment while the low efficiency for the recovery of fine coal is due to the low probability of bubble-particle collision. The expression for the combustible material recovery is given below:

$$
\mathrm{R}=\frac{Y_{C}\left(100-A_{C}\right)}{\left(100-A_{r}\right)} \%
$$

Where $\mathrm{R}$ is the combustible material recovery, $\mathrm{Y}_{\mathrm{c}}$ is the yield of clean coal, $\mathrm{A}_{\mathrm{c}}$ is the ash of clean coal, and $\mathrm{A}_{\mathrm{r}}$ is the ash of raw coal 


\subsection{Operating Parameters of Flotation}

Parameters that may affect the flotation efficiency include: physical and chemical properties of the feed material, components and configuration of the flotation system, the chemical reagents used in the flotation and the operation conditions applied in the froth flotation.

Froth flotation is based on the surface chemical properties of different mineral particles, while other properties such as particle size, particle density, solid concentration of the feed slurry and mineralogy are also important parameters. The particle size only in a narrow range between $38 \mu \mathrm{m}$ and $250 \mu \mathrm{m}$ can exert the highest efficiency of the froth flotation of fine coal which shows the particle size is an important parameter in conventional froth flotation. Particles with larger size can increase the probability of detachment while the smaller size could reduce the probability of the collision between air bubbles and particles. Fine particles with high density can also cause the detachment of the particles from air bubbles due to the gravity force, thus the density of particles also plays an important role in flotation. The solid concentration in the slurry will affect the settling velocity of the individual particle, as the higher the concentration, the larger the hindering effect during preparation. Therefore the solid concentration is significant in the recovery of the fine particles.

The typical stirred tank flotation cell is shown in Figure 2-2, In the flotation procedure, flotation feed is firstly mixed with chemical reagents in a tank called conditioning. The coal slurry is stirred by the impeller by several minutes without the injection of air. Then the air is allowed to form air bubbles around the impeller caused by the negative air pressure which is created by the rotation of the impeller. In coal 
industry, the widely used flotation apparatuses are stirred tank cell, open column cell (Figure 2-3) and aspiration column cell (Figure 2-4) in preparation plants (Cowburn et al., 2006; Lahey et al., 1998). The stirred tank flotation cell and flotation column cell are the two most applied flotation equipment in the coal industry. The stirred tank flotation cell has an impeller which can agitate the coal slurry that the mechanical power is applied to assist the flotation. While the column flotation cell has no mechanical force, the air bubble is injected from the lower part of the column. In comparing these two equipment, the traditional stirred tank flotation cell can provide more energy in the flotation system while the flotation column can provide longer residence time of fine particles, and washing water system. The recovery results and economic efficiency depends on the flotation properties of feed coal, reagents used and flotation devices selected.

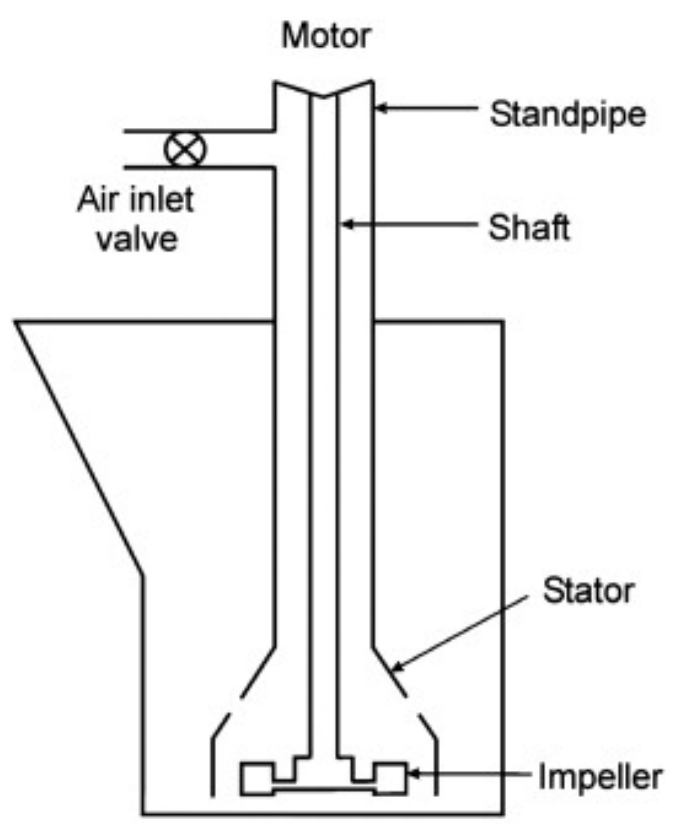

Figure 2-2 Schematic diagram of a stirred tank flotation flotation cell (Koh and Schwarz, 2007). 


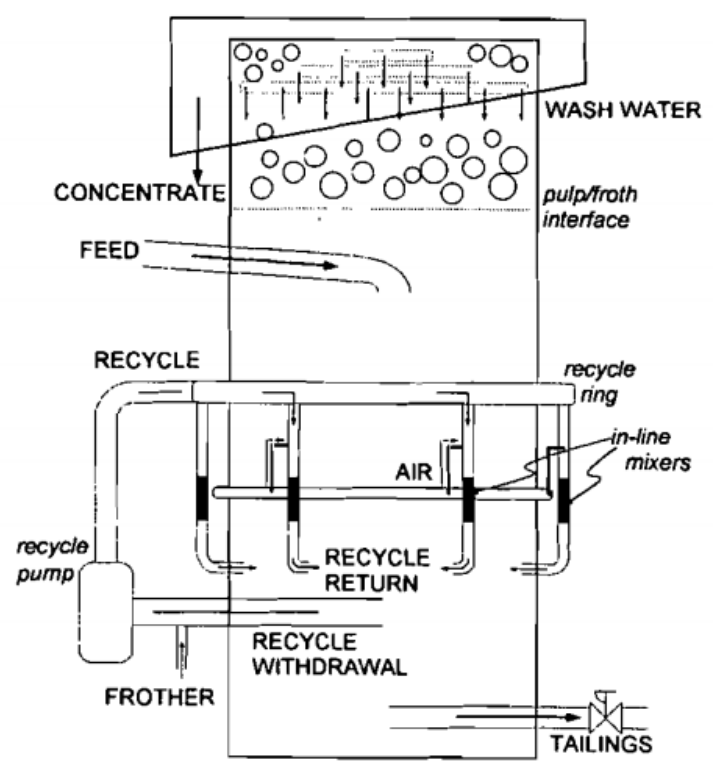

Figure 2-3 Schematic diagram of the microbubble flotation cell (Cowburn et al., 2006).

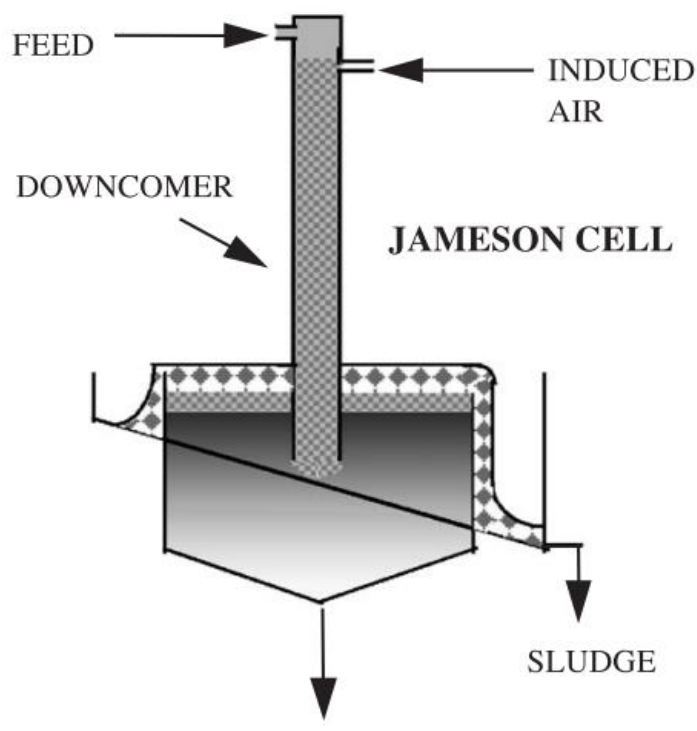

EFFLUENT

Figure 2-4 Schematic diagram of the Jameson flotation cell (Lahey et al., 1998). 


\subsection{Chemical Reagents for Flotation}

The principle of froth flotation is based on the surface chemical properties of fine particles, which can be regulated by many chemical reagents. These chemical reagents can be divided into different groups based on their effect in the froth flotation: collector, frother, modifier, promoter, and depressant. For collectors, it can subdivided into ionic (anionic and cationic) and non-ionic surfactants according to their electrical charge of polar group (Sis et al., 2003). Frothers can be separated into three groups based on the frother behavior at different $\mathrm{pH}$ values: acidic frother, neutral frother, and basic frother. The acidic frothers can perform well only in acidic solutions; basic frothers are used for flotation of base-metal ores; while the neutral frothers are functional in both acidic and alkaline pulps (Khoshdast and Sam, 2011). Phenols and alkyl sulfonates belong to the acidic frothers; pyridine base is the basic frother; neutral frothers include aliphatic alcohol, cyclic alcohols, alkoxy paraffins.

In coal industry, the most generally used collectors are kerosene and fuel oil no. 2, and MIBC (methyl isobutyl carbinol) and polyglycol ether are used as the frothers. Though the natural surface property of coal is hydrophobicity, these oily collectors are needed to enhance the hydrophobicity and floatability of the fine coal.

As for collectors, the fuel oil no.2, which is aliphatic hydrocarbon oil, distilled from the crude oil, is the most commonly one used in coal preparation plants. The oil can physically adsorb on some part of the coal surface that shows hydrophobicity. When the oil is adsorbed on the coal surface, the hydrophobicity of the coal is improved in that it can attach on the air bubbles after collision more easily. The length of the hydrocarbon chain of collectors is the key part that can increase the hydrophobicity of the fine coal. If the coal is oxidized, most area of the coal surface is 
hydrophilic, that the collectors can only exert a limited enhancement on the combustible material recovery of flotation.

The frothers have several mechanisms to affect the flotation efficiency when added with collectors (Dey, 2012). If they are to act as emulsifiers, it can assist in dispersing the big oil droplets into small ones, which contributes to the flotation kinetics by increasing the particle-oil droplet collision because of the larger amount of fine oil droplets. Frothers also can reduce the energy requirement when the collector oil is spreading the coal surface by adsorption in the solid-water interface and solid-air interface. When the frother is in low concentrations, it can act as a promoter to make the coal hydrophobic, which leads to a high probability of attachment of coal particles to the air bubbles. When the frother is in high concentration, it can make the coal surface hydrophilic through wetting the coal by water, that the frother finally reduces the recovery of coal. The frother itself is a surfactant that can reduce the surface tension at the liquid-vapor interface. In this condition, the big air bubbles can be separated into many tiny bubbles and become stable until they reach the froth.

\subsection{Properties of Oxidized Coal}

One important factor that makes the coal difficult to float is the oxidation of the coal surface. The oxidized coal has poor natural floatability, and high dosages of collectors are needed to float it (Tao et al., 2001), with some limitation. The surface of oxidized coal can be covered by oxygenated hydrophilic groups. Oxidization of coal has the content of oxygen functional groups such as carbonyl, carboxyl, and phenol. Its balance of hydrophobic and hydrophilic has been changed which reduces the natural hydrophobicity of the coal. These functional groups have an effect on the 
flotation of coal both in thermodynamics and kinetics. The phenolic and carboxylic groups belong to the ionic group which can affect the surface charge of coal and then change the film-thinning process and flotation kinetics. The polyvalent cations such as ferrous ion, ferric ion and aluminum ion can reduce or reverse the surface charge of oxidized coal. The oxidized coal often cannot be resurfaced by a single oily collector alone, even when using of high dosages of collector due to their porous surface, and high concentration of oxygenated hydrophilic group.

\subsection{Reagents for Flotation of Difficult-to-Float Coal/Oxidized Coal}

The flotation performance of oxidized coal can be enhanced when the hydrophilic parts of its surface are modified through the interaction between the coal particle and chemical reagents. The pine oil and MIBC have proved to be useful for the flotation of oxidized coal. The use of special flotation procedure of direct contact flotation, which only mixes the fine particles and chemical reagents without the addition of water in the conditioning process, and the application of microemulsion has been found to provide high selective flotation on the difficult-to-float coal (Ahmed, 2012).

The series of Tetrahydrofurfuryl esters (THF esters) were found to be effective as collectors for the flotation of oxidized coal (Jia et al., 2000), compared with the dodecane as collectors. THF collectors can have the same combustible matter recovery of flotation of oxidized coal with much lower dosage. This show the THF esters are able to restore the floatability of oxidized coal. However, if the collector concentration is too high, it can form a bilayer film over the surface of oxidized coal, which can reversely reduce the floatability of the coal. The structure of THF series can be shown in Figure 2-5. 


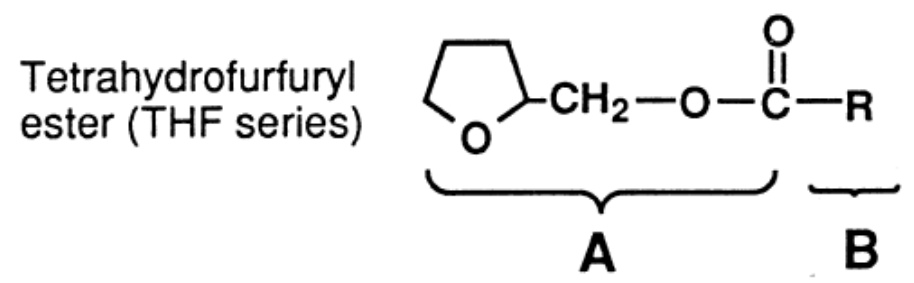

Figure 2-5 Structure of THF series (Jia et al., 2000).

Glycol-based frother P948 from Ciba Specialty Chemistry, Switzerland, and the collector SPP from CYTEC, New Jersey, were found to enhance the flotation of oxidized coal efficiency (Tao et al., 2002). The frother of $0.5 \mathrm{~kg} / \mathrm{mt}$ P947 and the frother of $1.5 \mathrm{~kg} / \mathrm{mt} \mathrm{SPP} \mathrm{can} \mathrm{lead} \mathrm{to} \mathrm{double} \mathrm{flotation} \mathrm{yield,} \mathrm{combustible} \mathrm{recovery} \mathrm{and}$ lower product ash compared to the traditional reagents such as MIBC and fuel oil at 1 $\mathrm{kg} / \mathrm{mt}$ and $15 \mathrm{~kg} / \mathrm{mt}$ respectively. In addition, the lower usage of P948 frother and SPP collector also can have much lower flotation cost. The petroleum sulfonate contained in SPP collector performs as an emulsifier, and can help the fuel oil separate into small droplets through agitation, which made it more efficiently adsorb on the surface of oxidized coal.

Cationic reagents such as amine were also found to improve the separation results of the oxidized coal (Sarikaya and Ozbayoglu, 1995). The combustible material recovery of oxidized coal can reach 70 percent. The floatability of the oxidized coal using cationic collectors drops when increasing the $\mathrm{pH}$ values. The cationic collector can shift the IEP (iso-electric point) of oxidized coal to $\mathrm{pH}$ values between 9.3 and 10.9 that are based on the type and concentration of collector. Because the oxidized coal has negative charged surfaces, and the hydrophobic sites on the surface was small due to the oxidization. The contact angle also improved to $75^{\circ}$ by using the 
cationic collector compared to $7^{\circ}$ as the natural oxidized coal contact angle.

Xanthate was also used as a pyrite depressant in the coal flotation (Fuerstenau et al., 1990). The addition of xanthate shows improvement of flotation efficiency at $\mathrm{pH}$ 6-8. When the solution $\mathrm{pH}$ is at 6 , the xanthate can reduce the product ash content and improve the rejection ash with concentration of $0.2 \mathrm{~kg} / \mathrm{mt}$. It can improve the quality of clean coal.

Fatty acid has been used as a promoter and collector for oxidized coal (Dube, 2012). Fatty acids are commonly synthesized from vegetable fat and animal fat, especially the vegetable oil which is comprised of varieties of fatty acids. Olive oil mixed with soybean oil has been provided to increase the combustible recovery for low rank coals. These oil droplets can agglomerate fine coal particles at low concentrations so that they interact with fatty acids through hydrogen bonding. When all the fatty acids act as collectors in coal flotation, it can enhance the combustible material recovery. The tall oil can aid in reducing the surface tension of coal slurry then further increase the surface area of air bubbles. The use of fatty acids in combination with the kerosene can promote the flotation efficiency of oxidized coal. The mixture of fatty acids with kerosene is better than the use of a single fatty acid which can aid in forming different adsorption capabilities. Thus the fatty acid mixtures can get a much higher recovery of coal flotation by the adsorption of oil droplets on different oxygen groups on the coal surface. However, the ash content of the clean coal can be as high as $12 \%$

\subsection{Use of Polyglycol Ether as Frother}

Polyglycol ether has been used as a synthetic frother in the coal industry. It has 
good performance in preventing bubble coalescence and creates more stable and viscous foams in comparison with frothers of alcohol family such as MIBC and Alpha-terpineol (Gupta et al., 2007). Because the effect of frothers on the bubble size comes from its ability that prevents bubble coalescence, the degree of bubble coalescence will reduce when the concentration of frother is enhanced. There also exists a concentration point which is called the critical coalescence concentration, and when the concentration of frother reaches it, a non-coalescence environment is formed. If the concentration of frother is higher than the critical coalescence concentration, the bubble size will be independent of the frother concentration.

In terms of the surface tension, it decreases as the frother concentration increases. The polyglycol ether can reduce more surface tension than the alcohol frothers, which means the polyglycol frother is more active on the surface (Gupta et al., 2007). In addition, the polyglycol ether has lower adsorption loading than the alcohol family frothers. Because of this, the alcohol family frothers need smaller area per mole when adsorb on the air-water interface than the polyglycol ether. Polyglycol ether has higher molecular weight than MIBC which may cause higher viscosity and more stable froth film. MIBC has only one hydroxyl group to interact water and form a monolayer at the surface. While the polyglycol ether has many oxygenated groups which can interact with water through hydrogen bonding that leads to the frother molecules lying at the surface, which enhances the viscosity and stability of the froth.

Polyglycol ether frother is more efficient in producing clean coal with comparative higher ash (12\%) (Gupta et al., 2007). While alcohol frothers are good at separating clean coal with lower ash (8.5\%-10\%). In addition, the polyglycol ether frother leads to a higher rate of recovery compared to the alcohol frothers. The 
polyglycol ether frother can separate oversize particles $(-1+0.5 \mathrm{~mm})$ and intermediate size $(-0.05+0.075)$ in recovery and grade. The alcohol frothers are good at recovering ultrafine coal particles and producing clean coal with lower ash content. Additionally, due to polyglycol ether frother can produce more stable froth film. This might cause the downstream filtration for dewatering problem.

\subsection{Foamability of Frothers}

As for the foamability, a concept called dynamic foamability index (DFI) (Laskowski et al., 2003) has been used for testing the performance of flotation frothers. The DFI is defined as follows:

$$
D F I=\left(\frac{\delta \mathrm{rt}}{\delta C}\right)_{C \rightarrow 0}
$$

Where the $\mathrm{rt}$ is the retention time in the solution and $\mathrm{C}$ is the frother concentration. According to the dynamic foamability index, the polyglycol ether has better foamability than the alcohol frothers (Gupta et al., 2007). The polyglycol ether frother can create higher froth volume than the alcohol frothers. The froth height increases when either the frother concentration or air flow rate increases. The polyglycol ether frother can perform high foaming ability at comparatively low concentration. The MIBC has relatively poor frothing efficiency because of its low retention time in solution.

The polyglycol ether has higher collapse time than the alcohol frothers (Gupta et al., 2007). The collapse time increases accompany the faster air flow rate and finally can reach a plateau. In addition, the collapse time also becomes longer accompany with the concentration becoming thicker. Because the polyglycol ether frother has 
higher collapse time, it can form more stable air bubbles. The foam stability of all frothers enhances with the increasing concentration at low levels, and this trend will change to a plateau region when the concentration is in high level. Therefore the foam stability is associated with the types of frother, the concentration of frother and the bubble generating system.

In the slurry, the air bubble size will decrease with the increase of frother concentration, and when it reaches a particular concentration, the bubble size becomes stable (Gupta et al., 2007). Bubble size is controlled through reducing bubble coalescence in the solution by frothers. When the concentration exceeds the critical coalescence value, the coalescence can be entirely eliminated in a dynamic system. If the frother condition exceeds this critical value, the slurry environment can be defined as non-coalescing. Since different types of frother have different critical coalescence concentration, the polyglycol ether frother can provide this environment at lower concentration than the alcohol frothers. MIBC can produce smaller and more homogeneous distributed size air bubbles and it is a more effective frother in terms of bubble size reduction than the polyglycol ether frother. These characteristics show that the frother can hinder coalescence and influence the bubble break-up mechanism.

\subsection{Methods to Improve the Flotation of Difficult-to-Float Coal}

Some investigators treat the difficult-to-float coal during the grinding process with the addition of pitch (Atesok and Celik, 2000). In their research, the addition of pitch during the grinding process in the presence of collectors can significantly increase the recovery of clean coal. The penetration and adsorption of the pitch on the hydrophobic part of coal surface maybe the main reason for the improved flotation 
performance. If the viscosity of the pitch used in the grinding process, the recovery of product will be damaged to a great extent. The investigators also test the effect of heat during the pretreatment of the raw coal. The combustible material recovery decreases when the moisture content varies from $18 \%$ to $0 \%$ infers the addition of pitch brings the some water to the coal. The use of heat treatment to the coal at $400^{\circ} \mathrm{C}$ just gives a limited improvement to the recovery, while above $500^{\circ} \mathrm{C}$, it achieves a great enhancement. Thus the heat treatment may leads to a better balance of hydrophilic/hydrophobic content on the coal surface.

The ultrasonic and high-intensity conditioning has been studied by some investigators to improve the flotation of oxidized coal (Xia et al., 2013). The ultrasonic and high-intensity conditioning is used in the agitated vessel to remove the thin clay layer and oxidized layer on the oxidized coal surface. They both increase the flotation efficiency and combustible material recovery. In addition, more stable smaller bubbles can be created during flotation when ultrasonic or high-intensity conditioning is applied. The ultrasonic treatment proved to aid in the distribution of chemical reagents that assist their adsorption on the coal surface. However, the ultrasound technique is not economic for large scale process.

Microwave irradiation is studied to treat the difficult-to-float coal to improve its flotation performance (Xia et al., 2013). After the treatment of microwave irradiation, the moisture content decreases and accompanied with the increased combustible material recovery. After microwave treatment, the hydrophobicity of coal enhanced that maybe caused by the elimination of pore water, hydration water and some hydroxyl function group. In addition, the diffusion of volatile matter and the reorientation of function group on the coal surface may also occur after the 
microwave irradiation treatment.

Direct contact flotation is investigated to improve the distribution of the chemical reagents on the coal surface (Ahmed and Drzymala., 2012). The direct contact process is a new mechanism that mixes the fine particles with the chemical reagents without addition of water in the conditioning process. This technique can promote the dispersion and adsorption of the reagents on fine particles. Using this flotation procedure, a better selectivity can be achieved. In their experiments, the anhydrous flotation reagents in the form of microemulsions also employed provide very good flotation results. The oxidized coal using the direct contact of microemulsions can achieve $88 \%$ yield in clean coal with the consumption of reagents at $10 \mathrm{~kg} / \mathrm{mt}$.

\subsection{Pico and Nano Bubble Venturi Cavitation Tube for Column}

\section{Flotation}

In coal preparation, the generation of nanobubbles can be achieved by applying the venturi cavitation tube that proved to enhance the recovery of coarse particles and fine particles with lower reagents consumption. The better flotation of the coal particles might be caused by the bridging of bubbles between the hydrophobic surfaces (Zhou et al, 1997).

The study of the mechanisms of nanobubble that enhances the froth flotation of coal particles has been reported (Fan et al., 2010). They reported that the hydrophobic particles with larger contact angle are preferred as nucleate by nanobubbles. The increasing of the frother dosage can reduce the nanobubble size. The increase of dissolved oxygen gas and the carbon dioxide gas concentration can also leads to the increase of nanobubble size. The number of hydrophobic nanoparticles $(<50 \mathrm{~nm})$ 
suspended in water can obviously increase the nanobubble size by acting as the nuclei. The increase of the pressure drop within the cavitation tube can increase the median size of the nanobubbles. The increase of the nanobubble volume is accompanied by the enhancement of frother concentration. The Zeta potential of the nanobubbles generated by cavitation tube will decrease with the increase of the $\mathrm{pH}$ value. The enhancement of the stability of the nanobubbles can be achieved at lower frother concentration. The existence of nanobubbles can significantly reduce the bubble raising velocity. The air holdup is severely affected by the nanobubbles in the water.

In addition, the same research group also applied the nanobubbles in the flotation of coal and phosphate. They found that the when the $\mathrm{pH}$ varies from 8 to 12 , the zeta potentials of phosphate and nanobubbles is stable. The hydrophobic phosphate and coal particle surface is easier to be adsorbed by nanobubbles rather than the hydrophilic quartz particle surface. The enhancement of the contact angles of the coal and phosphate also achieved by the induction of nanobubbles to the surfactant solutions. The reduction of detachment is observed with the existence of nanobubbles which favors the froth flotation. The modified monobubble Hallimond tube flotation proved to have significant better effect on the collection efficiency especially on fine particles collection efficiency with the presence of nanobubbles. The specially designed nanobubble column flotation tests show the increment of the phosphate and coal particles flotation efficiency with the employment of nanobubbles.

Hart et al., 2002, designed to use a device including a cavitation unit in flotation feed. Various designs of the cavitation were tested in their research. Several feed samples were tested to choose the most responsive feed based on the cavitation. They also established the cavitation device on mechanical flotation cell, Jameson cell and 
Column flotation cell to test its performance. Their research shows the cavitation unit can induce the nucleation of picobubbles on the coal surface that can both enhance the flotation product yield and reduce the collector dosage used in flotation. The application of cavitation unit on the flotation feed can improve the combustible material recovery by $6 \%-12 \%$. The collector amount can also be reduced by $50 \%$ with the same combustible material recovery as no cavitation unit used. This shows cavitation unit can enhance the effect of collector in the flotation process. The cavitation unit can benefit flotation performance of mechanical flotation cell and column flotation cell, but does not improve the efficiency of Jameson cell significantly.

Tao et al., (2007) applied the picobubbles to float the finest coal which shows better flotation performance than normal flotation method. Their study shows the picobubbles can significantly enhance the efficiency of the froth flotation with higher recovery and low product ash. The recovery the fine coal can be improved by 10 to 30 percent according to the operation conditions, using the normal flotation method. The collector dosage can be reduced about one half by applying the pico and nano bubbles. The frother dosage can also be reduced up to one half. The improved flotation efficiency is due to the increased probabilities of collision and attachment and reduced probability of detachment.

\subsection{Cyclo-Microbubble Flotation}

The cyclo-microbubble flotation column (CMFC) to recover the fine coal from discarded waste ponds was studied by Li et al. (2006). They reported that the CMFC was excellent in the preparation of nominally fine coal $(<0.5 \mathrm{~mm})$. Their industrial 
testing proved that the commercial CMFC could produce $90 \%$ of combustible material recovery and $57 \%$ of separation efficiency with the coal of $0.25-0.074 \mathrm{~mm}$ and $<0.045 \mathrm{~mm}$ fractions. CMFC also shows good efficiency in cleaning fine coal waste. $9.66-10.93 \%$ ash of clean coal was produced from the raw coal contains $47.11 \%$ ash with yield of $45.71-47.41 \%$. In addition, they also use the CMFC to produce ultraclean coal with the clean coal ash of $1.5-1.8 \%$ for Taixi coal.

The double funnel tailings separator applied in the flotation column can improve the flotation performance. Its working principles and working parameters have been studied by Yang et al. (2007) and Zhang et al. (2006). The application of this separator in the flotation of camp rock has been studied (Zhou et al., 2003; Zhou, et al., 2005; Chen, et al., 2008). The application of this separator in coal preparation was also studied to improve the coal recovery and quality (Wang, 2008; Liu, 2006) 


\section{CHAPTER 3 \\ EXPERIMENTS}

\subsection{Material}

The coal sample used in the series of experiments is subbituminous coal and it was employed to study the effect of pico and nano bubble and the blend of Trimethyl Pentanediol Derivatives as frother on the difficult-to-float coal flotation performance. The blend of trimethyl pentanediol derivatives consists of trimethyl pentanediol monoisobutyrate, trimethyl pentanediol diisobutyrate and trimethyl pentanediol. Since the major components of this frother have long chemical names, TTT frother will be used throughout this study. TTT frother is obtained from Zinkan Enterprises Inc. The raw coal sample used in the experiment is subbituminous coal that has $23-26 \%$ of ash content. Approximately $300 \mathrm{lbs}$ of the subbituminous coal was received, spread and air dried for four days, then using Cone and Quarter Technique to divide the coal sample into several small homogeneous portions.

The coal particles larger than 2-inches were broken by the hammer. Each portion of the coal sample was passed through the jaw crusher and double roll crusher that producing coal particle size to about 1/4 inches size range. Then Quaker mill and Holmes mill were used further to reduce the coal particle sizes to minus $250 \mu \mathrm{m}$ (USA No. 60) . The size reduction process is shown below: 


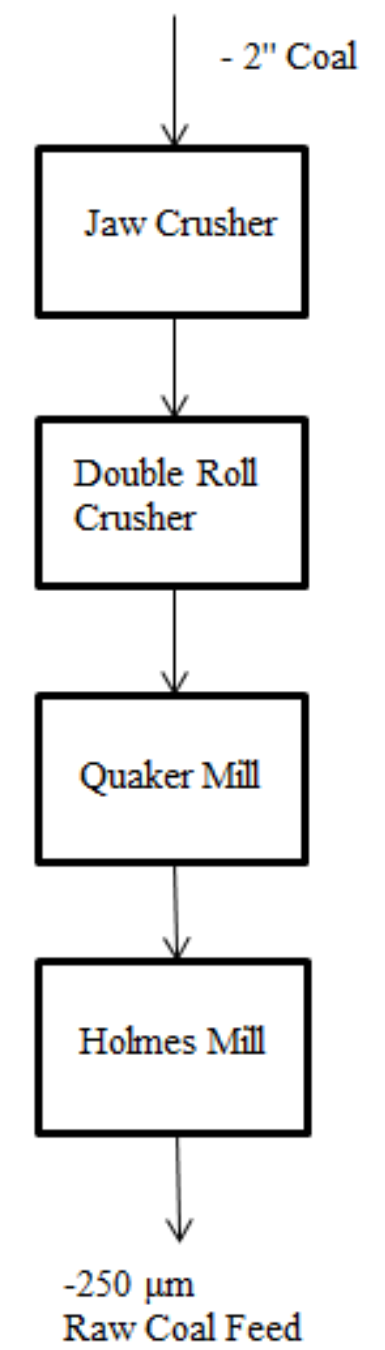

Figure 3-1 Schematic diagram of the crushing treatment for the raw coal.

The proximate analysis of the flotation feed was tested. The typical sampleresults was shown in Table 3-1

Table 3-1 Proximate analysis of the fine feed.

\begin{tabular}{|c|c|}
\hline Component & $\mathrm{Wt}, \%$ \\
\hline Moisture & 8.00 \\
\hline Volatile Matter & 38.90 \\
\hline Ash & 23.10 \\
\hline Fixed Carbon & 30.00 \\
\hline Total & 100.00 \\
\hline
\end{tabular}


The proximate analysis shows that the volatile matter has $38.9 \%$ of the total raw coal weight while the fixed carbon only account for $30 \%$ of the total weight. This may be due to high ash content in the feed.

The coal particle larger than 1 inch can be used for the contact angle measurement. Coal particle was polished smooth on the top and bottom surfaces using the sand paper. Both sides of the surfaces have the area about $4 \mathrm{~cm}^{2}$ and its thickness is about $1 \mathrm{~cm}$. When conducting the contact angle measurement, the polished coal sample was placed on the platform of the rame-hart Goniometer 100. About 1/10 ml of the distilled/deionized water was dispelled by the syringe on the coal surface. The contact angle of the coal sample should be read immediately after the water drop was placed on the coal surface. The contact angle of the coal surface was read based on the tangent line of the liquid/air interface. The contact angle of the coal sample is $38 \pm 2$ degrees. The low value of contact angle reflects the low degree of hydrophobicity of coal particles. This result suggests that the coal surface should be modified before flotation process.

\subsection{Experiment Procedures}

\subsubsection{Stirred Tank Cell Flotation}

Denver Model D-12 laboratory automated flotation machine was employed to conduct the froth flotation of fine coal sample. The semi-batch flotation as a function of time was obtained for the flotation of fine coal. The fine coal sample of $200 \mathrm{~g}$ was mixed with $500 \mathrm{ml}$ distilled/deionized water and conditioned in a 4 liter flotation tank for $10 \mathrm{~min}$. The well wetted coal slurry was poured into a 2 liter flotation cell. The slurry volume was adjusted by additional distilled/deionized water to about 2 liter. 
Impeller was turned on and frother was added for 5 minute conditioning. Collector was then added for another 5 minute conditioning. The operating parameters for semi-batch cell flotation are given in Table 3-2

Table 3-2 Operation conditions of stirred tank cell flotation.

\begin{tabular}{|c|c|c|c|}
\hline Coal & $200 \mathrm{~g}$ & Conditioning time & $10 \mathrm{~min}$ \\
\hline Solid concentration & $9.10 \%$ & Impeller speed (Conditioning) & $1200 \mathrm{rpm}$ \\
\hline Impeller speed (Flotation) & $1100 \mathrm{rpm}$ & Collector conditioning time & $5 \mathrm{~min}$ \\
\hline Frother conditioning time & $5 \mathrm{~min}$ & Flotation cell volume & 2 liter \\
\hline Air flow rate & $2.67 \mathrm{~cm} / \mathrm{s}$ & Frother dosage & $0.06 \mathrm{~kg} / \mathrm{mt}$ \\
\hline Collector dosage & $1 \mathrm{~kg} / \mathrm{mt}$ & & \\
\hline
\end{tabular}

When test the flotation rate of the stirred tank cell flotation, the clean coal was collected at the intervals: $0 \mathrm{~s}, 15 \mathrm{~s}, 30 \mathrm{~s}, 45 \mathrm{~s}, 60 \mathrm{~s}, 90 \mathrm{~s}, 120 \mathrm{~s}$, and $180 \mathrm{~s}$. The tailings were collected in the bottom of the cell.

\subsubsection{Release Analysis Experiment}

The release analysis experiments use one time roughing, and following a series of cleaning to determine the floatability and flotation performance of the feed coal. It determined the ideal flotation conditions to achieve the maximum recovery and minimum clean coal product ash content. The detailed flotation procedure for the release analysis is given by Randolph (1997). This procedure has similar function of density washability analysis which is used for the coarse particles sample. In the first roughing stage, the coal was floated following the pre-wetting conditions, and reagent conditioning. For cleaning stage, the clean coal obtained from the previous step was diluted to total 2 liter coal slurry and then apply the flotation. Repeat this process for 4 times for the concentration stage. Finally one clean coal and five tailings can be 
obtained. In the release analysis flotation experiment, kerosene was used as collector and TTT frother was used as frother. In this set of experiments, the kerosene usage is $2.5 \mathrm{~kg} / \mathrm{mt}$ and the TTT frother dosage is $0.35 \mathrm{~kg} / \mathrm{mt}$. The detailed procedure is shown in Figure 3-2.

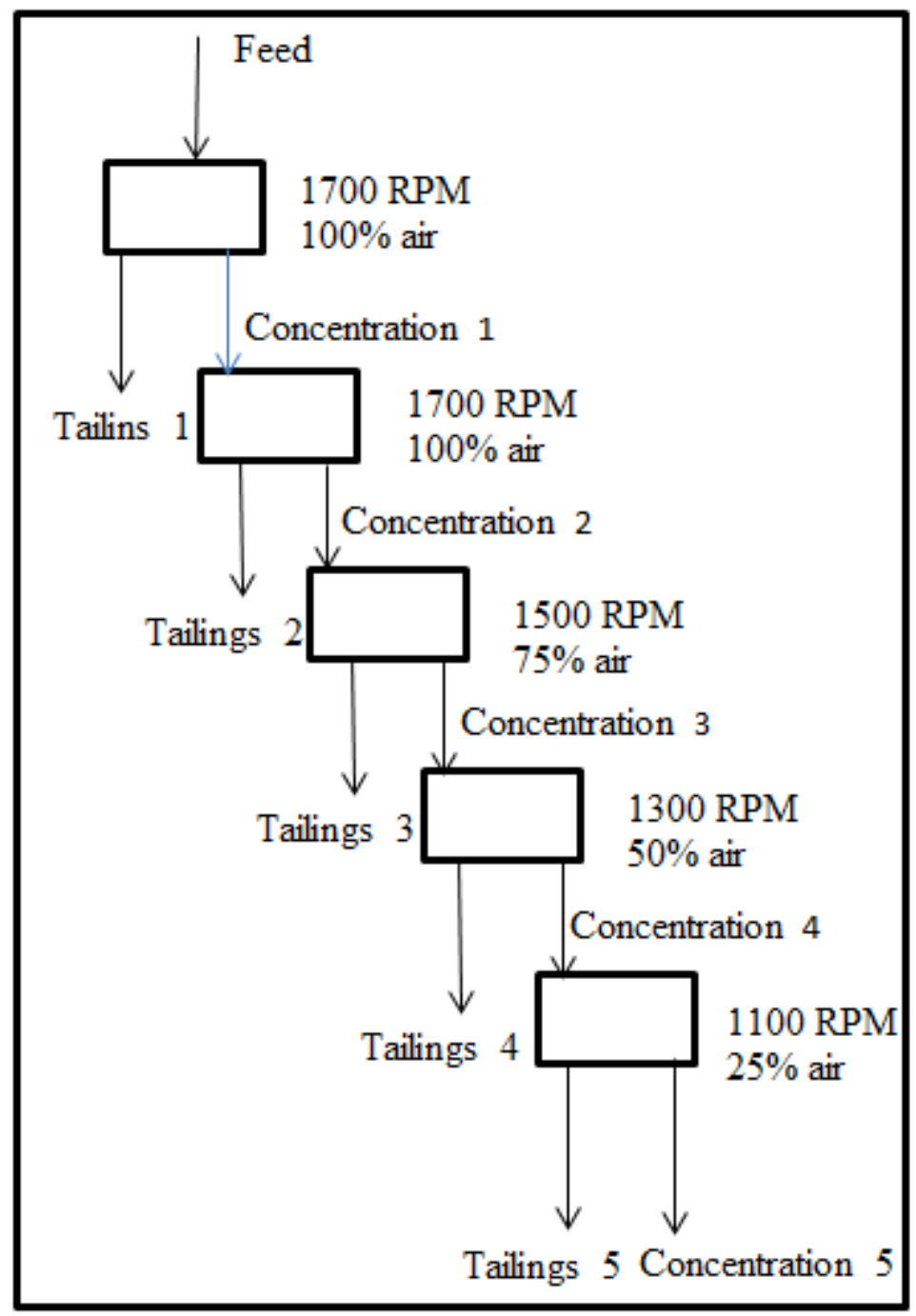

Figure 3-2 Schematic diagram of the release experiments.

From the procedure, for each cleaning stage, the concentrate from the previous flotation test was diluted to 2 liter coal slurry without addition of any reagents. Thus 
only the coal particles with better floatability can be floated. The release flotation experiments results is presented in Table 3-3.

Table 3-3 Results of release experiments.

\begin{tabular}{|l|c|c|l|c|c|}
\hline & $\mathrm{Wt}, \%$ & $\mathrm{Ash}, \%$ & & $\mathrm{Wt}, \%$ & Ash, \% \\
\hline Concentration 1 & 84.97 & 18.27 & Tailings 1 & 29.56 & 60.09 \\
\hline Concentration 2 & 79.32 & 15.32 & Tailings 2 & 14.53 & 51.39 \\
\hline Concentration 3 & 76.16 & 13.64 & Tailings 3 & 8.87 & 46.10 \\
\hline Concentration 4 & 73.25 & 12.48 & Tailings 4 & 5.71 & 40.80 \\
\hline Concentration 5 & 70.44 & 11.44 & Tailings 5 & 2.81 & 38.48 \\
\hline
\end{tabular}

From the release analysis, the cleanest concentrate can be obtained with combustible material recovery of $84.1 \%$ and clean coal ash content of $10.44 \%$. These results show a good floatability of the subbituminous coal sample obtained by using the kerosene as collector and TTT frother as frother, which leads to high combustible material recovery and low ash content of the cleanest coal. It is possible to obtain the clean coal of lower ash content with lower dosage of kerosene. However, it produces lower combustible material recovery.

\subsubsection{Column Flotation Experiments}

Column flotation provides an efficient way to wash froth compared to the stirred tank cell flotation. However the conventional open column flotation usually consumes chemical reagents much less than that of the stirred tank cell flotation. The flotation column has a long flotation region which allows coal particles stay much longer in the flotation column than the stirred tank cell flotation, which highly improves the probabilities of collision and attachment between the coal particles and the air bubbles. During the column flotation, it can form a froth region at the top of the column. In 
addition, a wash water system also set on the upper portion of the column which provides continuous spreading of wash water. In the froth region, the mineral particles which are hydrophilic but brought to the upper portion of the column due to the hydraulic entrainment effect can be eliminated by the wash water.

The laboratory flotation column used in these experiments has the height of 250 $\mathrm{cm}$ including the height of double funnel separator and the inner diameter of $5 \mathrm{~cm}$, which has the ratio of length to diameter of 50:1. The flotation column used in this study has equipped with a new set of bubble generation system and a double funnel tailings separator. In the conventional flotation column, the air bubbles are generated either by a static mixer for micro bubbles or a sparger with numerous micro-pores for small bubble generation. In the new bubble generating system, a static mixer connected to a venturi cavitation tube is used to generate the pico and nano bubbles. The schematic diagram of the flotation column used in this study is given in Figure 3-3. One pump (pump 1, peristaltic pump, cole-parmer) is employed to pump the tailings slurry from the bottom of column which contains most of the coal tailings contained frother in the slurry through the inner funnel double funnel tailings separator. The air was injected into the tailings slurry stream from the outer funnel before entering peristaltic the pump (pump 2, peristaltic pump, cole-parmer). The mixture of air and coal tailings then passes through the static mixer for homogenous air-coal tailings stream and generation of micro bubbles. The micro bubbles and coal tailings pass through venturi cavitation tube to generate the pico and nano bubbles and further injected into the flotation column. This special designed flotation column equipped with tailings recirculating and pico and nano bubble generation system enhances the separation of coal and mineral particles. 
In this new designed flotation column, a cyclonic double funnel tailings separator system is applied to improve the separation and circulation efficiency. In this separator, a small funnel is in the inner part of the big funnel that they form a concentric conical shape. During the froth flotation process, a water cyclone can be formed above the separator similar to the inversed hydrocyclone and the can exert a cyclonic effect on the particles for its separation. Heavy particles will fall into the small funnel, while the light particles fall into the area between these two funnels. In this case, the tailings discharged from the small funnel (inner funnel) will contain more gangue particles due to the cyclonic effect. Thus the tailings slurry discharged from the small funnel will be pumped out as tailings, while the tailings slurry discharged between the two funnels will be recycled into the bubble generation system.

For the feed coal slurry preparation, coal sample was mixed with water, frother and collector by a stirrer in the feed tank and recirculation loop was used to achieve the chemical reagents coating on coal surface and uniform coal slurry. One pump (pump 3, peristaltic pump, cole-parmer) was used to circulate the coal slurry form the bottom of the sump to the top to achieve homogeneous coal slurry. In this procedure, the coal firstly mixed with water for 10 minutes, then frother is added for 5 minutes and then collector is added for another 5 minutes. After conditioning, the feed coal slurry was pumped into the flotation column by a peristaltic pump (pump 3, peristaltic pump, cole-parmer). When the feed coal slurry has reached about half the column height, bubble generation system was operated to generate the air bubbles. When the feed coal slurry reached the upper portion of the column, the wash water and the tailings recirculation were started. The water level must be kept stable in the column, 
and the top portion of the column must form a stable froth area during the flotation process. The wash water and air injection volume were monitored by the flow meter. When the flotation reaches steady state for more than 20 minutes, the clean coal and tailings began to be collected. The flotation conditions are shown in Table 3-4 unless the specific factors are changed in the experiments.

Table 3-4 Operation conditions of flotation column

\begin{tabular}{|c|c|}
\hline Feed rate & $0.43 \mathrm{~cm} / \mathrm{s}$ \\
\hline Solid concentration & $7 \%$ \\
\hline Collector dosage & $0.25 \mathrm{~kg} / \mathrm{mt}$ \\
\hline Frother dosage & $0.02 \mathrm{~kg} / \mathrm{mt}$ \\
\hline Gas flow rate & $2.5 \mathrm{~cm} / \mathrm{s}$ \\
\hline Wash water rate & $0.103 \mathrm{~cm} / \mathrm{s}$ \\
\hline Column length & $250 \mathrm{~cm}$ \\
\hline Column diameter & $7.65 \mathrm{~cm}$ \\
\hline
\end{tabular}




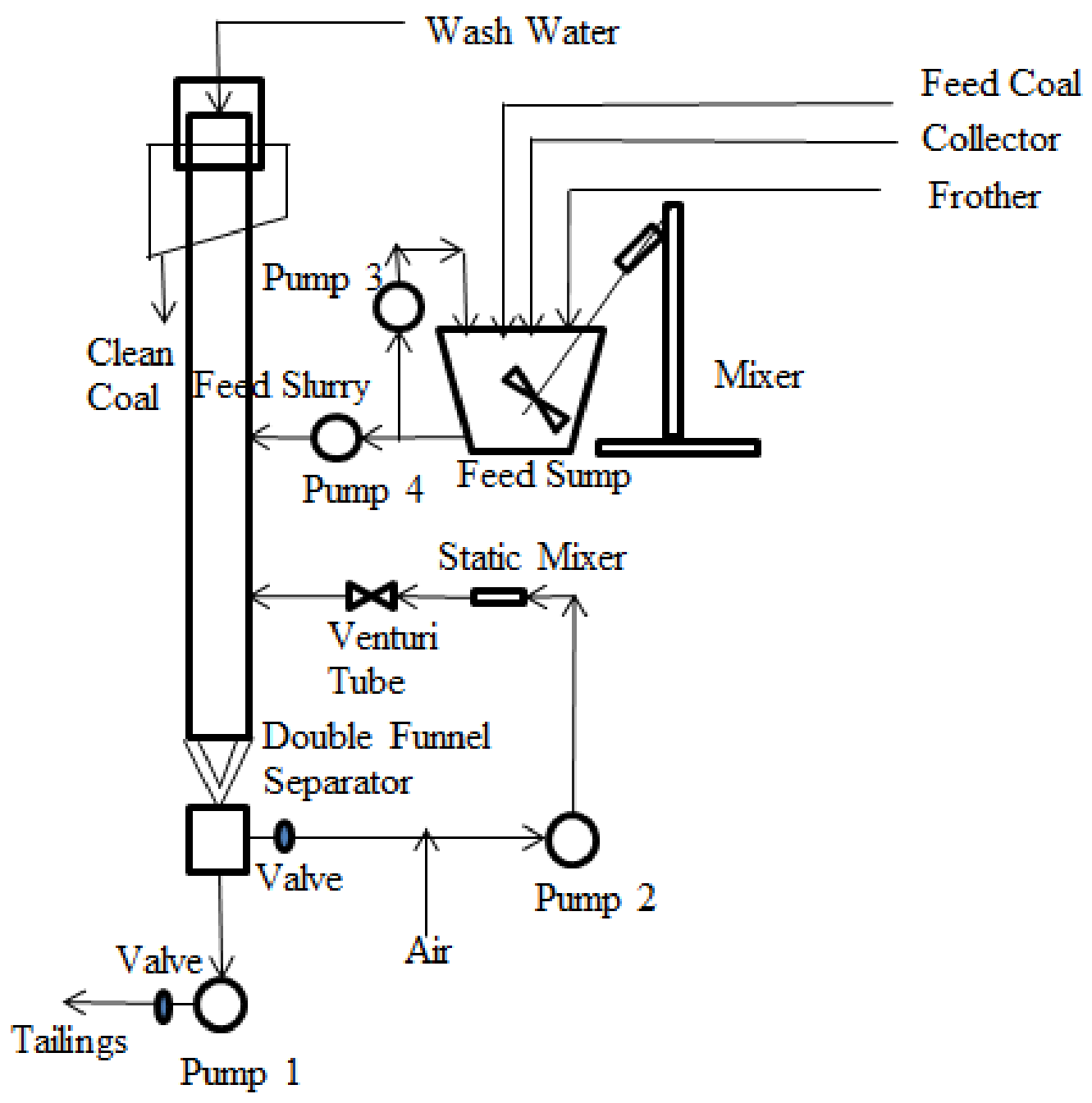

Figure 3-3 Schematic diagram of flotation column system.

To obtain product samples, the clean coal and tailings samples are collected for 1 minute, and then stop collecting for 1 minute. Repeat this procedure until the feed slurry is exhausted. The clean coal and tailings then filtered, and dried in the oven for 8 hours at $105{ }^{\circ} \mathrm{C}$. They are weighted and ash contents are determined using ASTM method (ASTM D317-12). 
The calculation of the combustible material recovery is shown in eq.(3-1):

$$
\mathrm{CMR} \%=Y_{c}\left(100-A_{c}\right) /\left(100-A_{f}\right)
$$

Where the $Y_{c}$ is the clean coal yield, $A_{c}$ is the clean coal ash content, and $A_{f}$ is the feed coal ash content.

In the conventional open flotation column, using conventional spargers or static-mixers, it is important to keep the depth of froth layer during column flotation. A stable sufficient deep particles coated froth layer provides enough time for the wash water to eliminate the entrained hydrophilic mineral particles trapped between air bubbles. The depth of the froth layer should contain more than $10 \mathrm{~cm}$ which can be controlled by balance of the tailings discharge rate, wash water rate and feed coal rate. The froth layer can also be used to judge the stability of the column flotation. Usually it takes about 15 minutes to obtain the stable froth layer and steady state in the flotation column. On the contrary, by utilizing pico and nano bubbles in the flotation column, the froth depth adjustment problem can be ignored. This is due to the high density distribution of pico and nano bubbles inside of column. This contributes to high probability of collision and attachment between coal particles and air bubbles. 


\section{CHAPTER 4 \\ RESULTS AND DISCUSSIONS}

\subsection{Particle Size Distribution}

Fine subbituminous raw coal is grinded to minus $250 \mu \mathrm{m}$ right before flotation. The grounded ultrafine coal sample was wet sieved to determine the particle size distribution. ASTM method of ash analysis was conducted on each size range of the sieved coal sample. The sieve result is presented in Table 4-1

Table 4-1 Particle size distribution and ash content of ultrafine feed coal.

\begin{tabular}{|c|c|c|c|c|c|}
\hline \multirow{2}{*}{$\begin{array}{c}\text { Size } \\
\text { (USA. No.) }\end{array}$} & \multirow{2}{*}{$\begin{array}{c}\text { Size, } \\
\mu \mathrm{m}\end{array}$} & \multicolumn{2}{|c|}{ Individual } & \multicolumn{2}{c|}{ Cumulative } \\
\cline { 3 - 6 } & $\mathrm{Wt}, \%$ & Ash, $\%$ & $\mathrm{Wt}, \%$ & Ash, $\%$ \\
\hline+60 & +250 & 4.44 & 17.34 & 100.00 & 23.65 \\
\hline$-60+100$ & $-250+150$ & 20.11 & 18.52 & 95.56 & 23.94 \\
\hline$-100+170$ & $-150+90$ & 22.72 & 21.8 & 75.45 & 25.39 \\
\hline$-170+325$ & $-90+45$ & 22.56 & 20.52 & 52.73 & 26.93 \\
\hline-325 & -45 & 30.17 & 31.73 & 30.17 & 31.73 \\
\hline
\end{tabular}

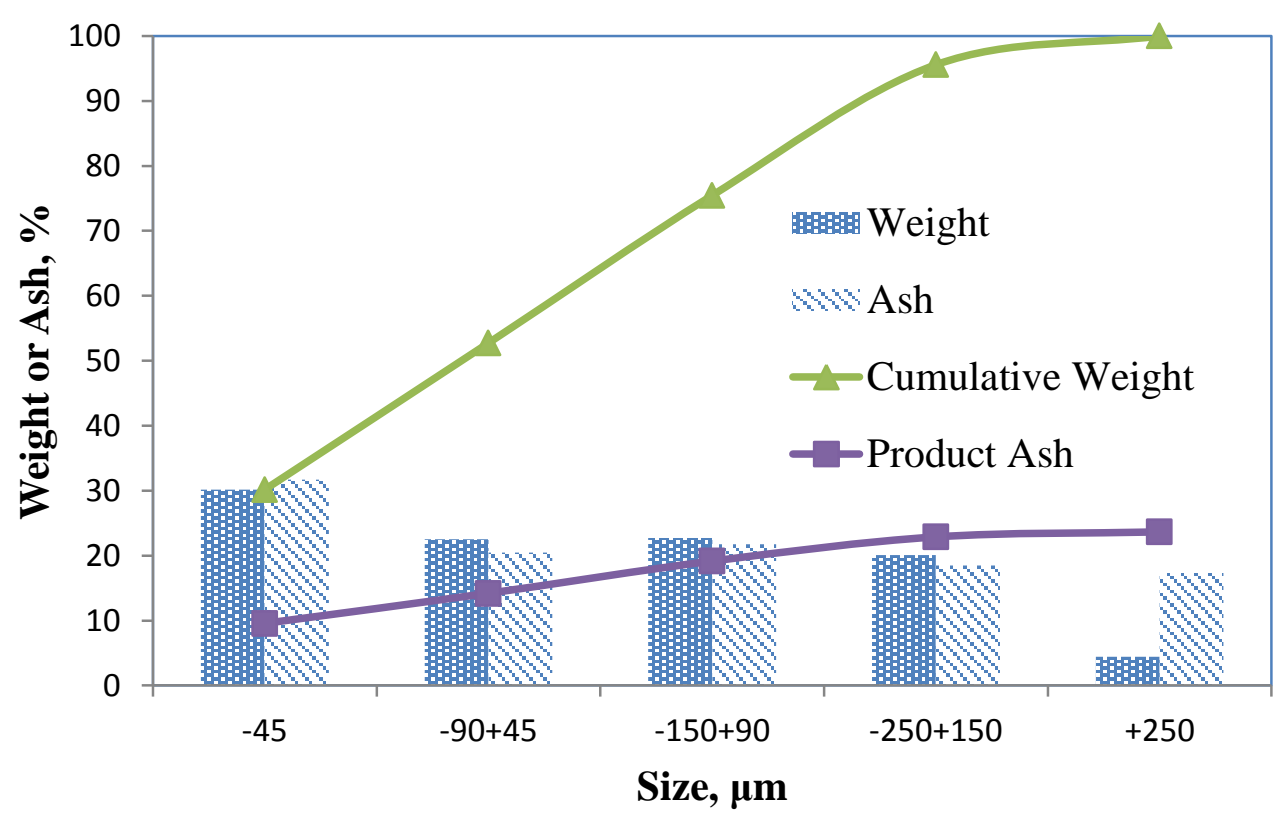

Figure 4-1 Weight and ash percent of the feed coal. 
From the sieving result, the ultrafine coal particles (minus $45 \mu \mathrm{m}$ ) have $30.17 \%$ of the total weight with ash content of $21.73 \%$. The coarse particles larger than 250 $\mu \mathrm{m}$ (USA No. 60) are $4.44 \%$ with ash content of $17.34 \%$. The ash content of ultrafine particles is the highest one among all the size ranges. This shows mineral particles that exist in the feed coal have very small size. These ultrafine mineral particles can cause the slime coating on the coal surface that affects clean coal quality directly.

\subsection{Flotation Rate of Stirred Tank Cell}

Two series of semi-batch cell flotation were conducted to test the floatability of subbituminous coal and the effect of TTT frother. Each series has three sets of experiments. In the first series of experiment, the first test was on the Pittsburgh \#8 coal using the kerosene as collector and MIBC as frother. The second test was on subbituminous coal using kerosene as collector and MIBC as frother. The third test was on the subbituminous coal using kerosene as collector and TTT frother as frother. In the second series of experiments, the collector dosage increased to $2 \mathrm{~kg} / \mathrm{mt}$ and the frother dosage increased to $0.3 \mathrm{~kg} / \mathrm{mt}$ while keeping the other operation conditions the same as the first series. Table 4-2 shows the flotation result using collector of 0.5 $\mathrm{kg} / \mathrm{mt}$ and frother of $0.02 \mathrm{~kg} / \mathrm{mt}$. Table $4-3$ shows the flotation result using collector of $2 \mathrm{~kg} / \mathrm{mt}$ and frother of $0.3 \mathrm{~kg} / \mathrm{mt}$. Figure $4-2$ and Figure $4-3$ that show the relationship between combustible material recovery, ash content and the flotation time. 
Table 4-2 Flotation rate results using collector of $0.5 \mathrm{~kg} / \mathrm{mt}$ and frother of $0.02 \mathrm{~kg} / \mathrm{mt}$.

\begin{tabular}{|c|c|c|c|c|c|c|c|c|c|}
\hline & \multicolumn{3}{|c|}{ Pittsburgh \#8-MIBC } & \multicolumn{3}{|c|}{ Subbituminous-MIBC } & \multicolumn{3}{|c|}{$\begin{array}{c}\text { Subbituminous Coal-TTT } \\
\text { frother }\end{array}$} \\
\hline Time, $\mathrm{s}$ & $\begin{array}{l}\text { Weight, } \\
\mathrm{g}\end{array}$ & Weight, \% & Ash, $\%$ & $\begin{array}{l}\text { Weight, } \\
\mathrm{g}\end{array}$ & Weight, \% & Ash, \% & $\begin{array}{l}\text { Weight, } \\
\mathrm{g}\end{array}$ & Weight, \% & Ash, \% \\
\hline 15 & 20.94 & 11.15 & 12.70 & 11.98 & 6.88 & 18.70 & 15.64 & 8.97 & 21.74 \\
\hline 30 & 20.14 & 10.72 & 11.35 & 10.39 & 5.97 & 19.03 & 13.16 & 7.55 & 19.98 \\
\hline 45 & 19.30 & 10.27 & 11.35 & 4.88 & 2.80 & 18.04 & 9.22 & 5.29 & 18.94 \\
\hline 60 & 20.32 & 10.82 & 11.62 & 2.39 & 1.37 & 17.41 & 4.53 & 2.60 & 18.28 \\
\hline 90 & 25.49 & 13.57 & 18.54 & 2.88 & 1.65 & 18.79 & 6.09 & 3.49 & 19.73 \\
\hline 120 & 15.22 & 8.10 & 27.52 & 1.21 & 0.69 & 20.40 & 3.47 & 1.99 & 21.42 \\
\hline 180 & 17.09 & 9.10 & 38.27 & 3.05 & 1.75 & 23.80 & 7.14 & 4.10 & 27.09 \\
\hline Tailings & 49.35 & 26.27 & 67.56 & 137.36 & 78.88 & 25.33 & 115.04 & 66.00 & 29.33 \\
\hline
\end{tabular}


Table 4-3 Flotation rate results using collector of $2 \mathrm{~kg} / \mathrm{mt}$ and frother of $0.3 \mathrm{~kg} / \mathrm{mt}$.

\begin{tabular}{|c|c|c|c|c|c|c|c|c|c|}
\hline & \multicolumn{3}{|c|}{ Pittsburgh \#8 coal-MIBC } & \multicolumn{3}{|c|}{ Subbituminous coal-MIBC } & \multicolumn{3}{|c|}{$\begin{array}{l}\text { Subbituminous Coal-TTT } \\
\text { frother }\end{array}$} \\
\hline Time, s & $\begin{array}{l}\text { Weight, } \\
\mathrm{g}\end{array}$ & Weight, \% & Ash, $\%$ & $\begin{array}{l}\text { Weight, } \\
\mathrm{g}\end{array}$ & Weight, $\%$ & Ash, \% & $\begin{array}{l}\text { Weight, } \\
\mathrm{g}\end{array}$ & Weight, \% & Ash, \% \\
\hline 15 & 29.1603 & 15.41 & 18.59 & 41.80 & 23.79 & 16.35 & 44.20 & 25.14 & 19.62 \\
\hline 30 & 23.9376 & 12.65 & 13.26 & 36.96 & 21.03 & 17.64 & 41.77 & 23.76 & 17.34 \\
\hline 45 & 22.9347 & 12.12 & 13.58 & 32.78 & 18.66 & 16.87 & 37.81 & 21.51 & 16.69 \\
\hline 60 & 24.4296 & 12.91 & 13.21 & 18.56 & 10.56 & 17.74 & 21.66 & 12.32 & 16.08 \\
\hline 90 & 29.8983 & 14.80 & 18.43 & 3.45 & 1.96 & 17.93 & 4.59 & 2.61 & 18.54 \\
\hline 120 & 15.5736 & 8.23 & 29.56 & 4.14 & 2.36 & 21.33 & 3.32 & 1.89 & 23.65 \\
\hline 180 & 3.99275 & 2.11 & 41.86 & 5.54 & 3.15 & 24.05 & 3.67 & 2.09 & 28.91 \\
\hline Tailings & 41.1954 & 21.77 & 76.53 & 32.48 & 18.49 & 54.89 & 18.78 & 10.68 & 64.31 \\
\hline
\end{tabular}




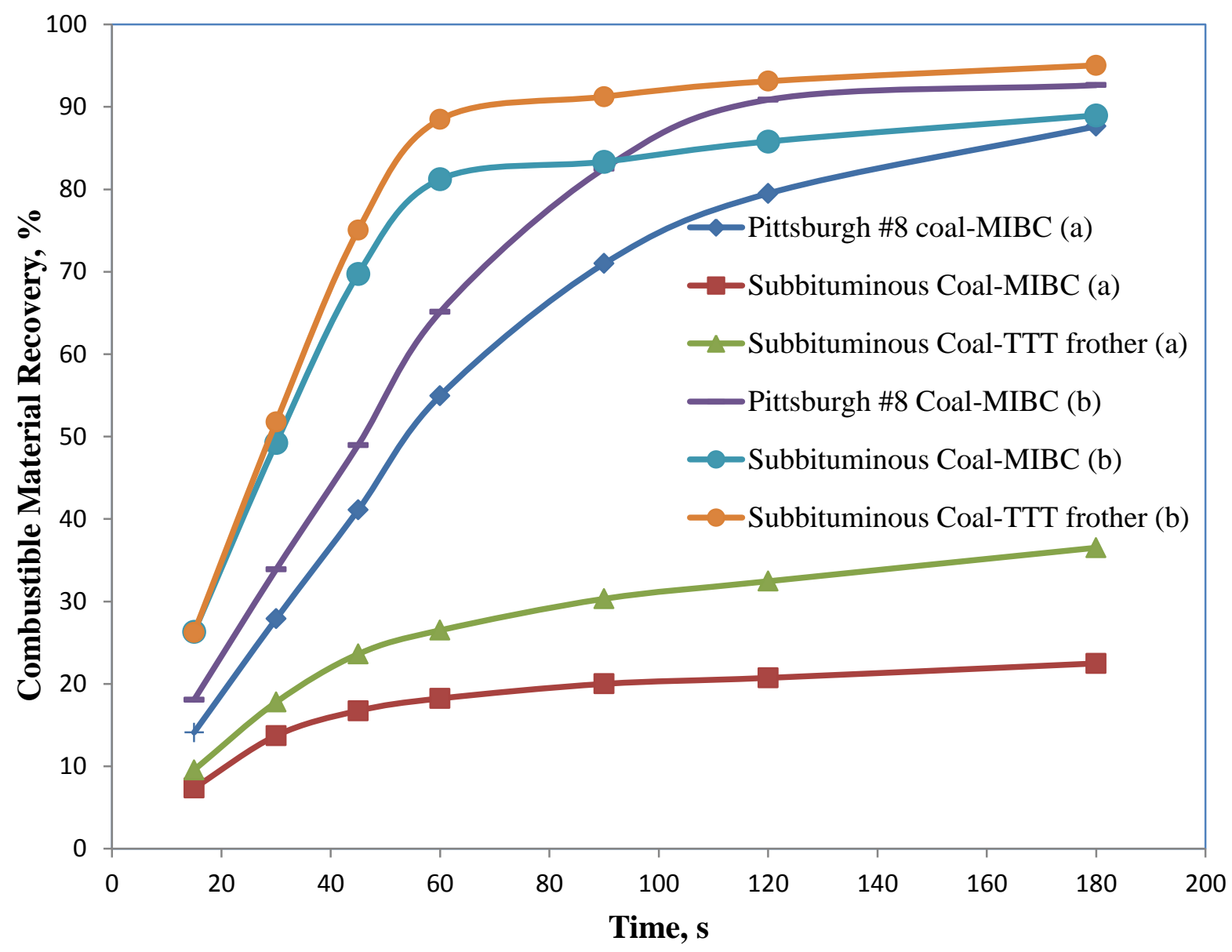

Figure 4-2 Combustible material recovery as a function of time (a) collector 0.5 $\mathrm{kg} / \mathrm{mt}$, frother $0.02 \mathrm{~kg} / \mathrm{mt}$ (b) and collector $2 \mathrm{~kg} / \mathrm{mt}$, frother $0.3 \mathrm{~kg} / \mathrm{mt}$. 


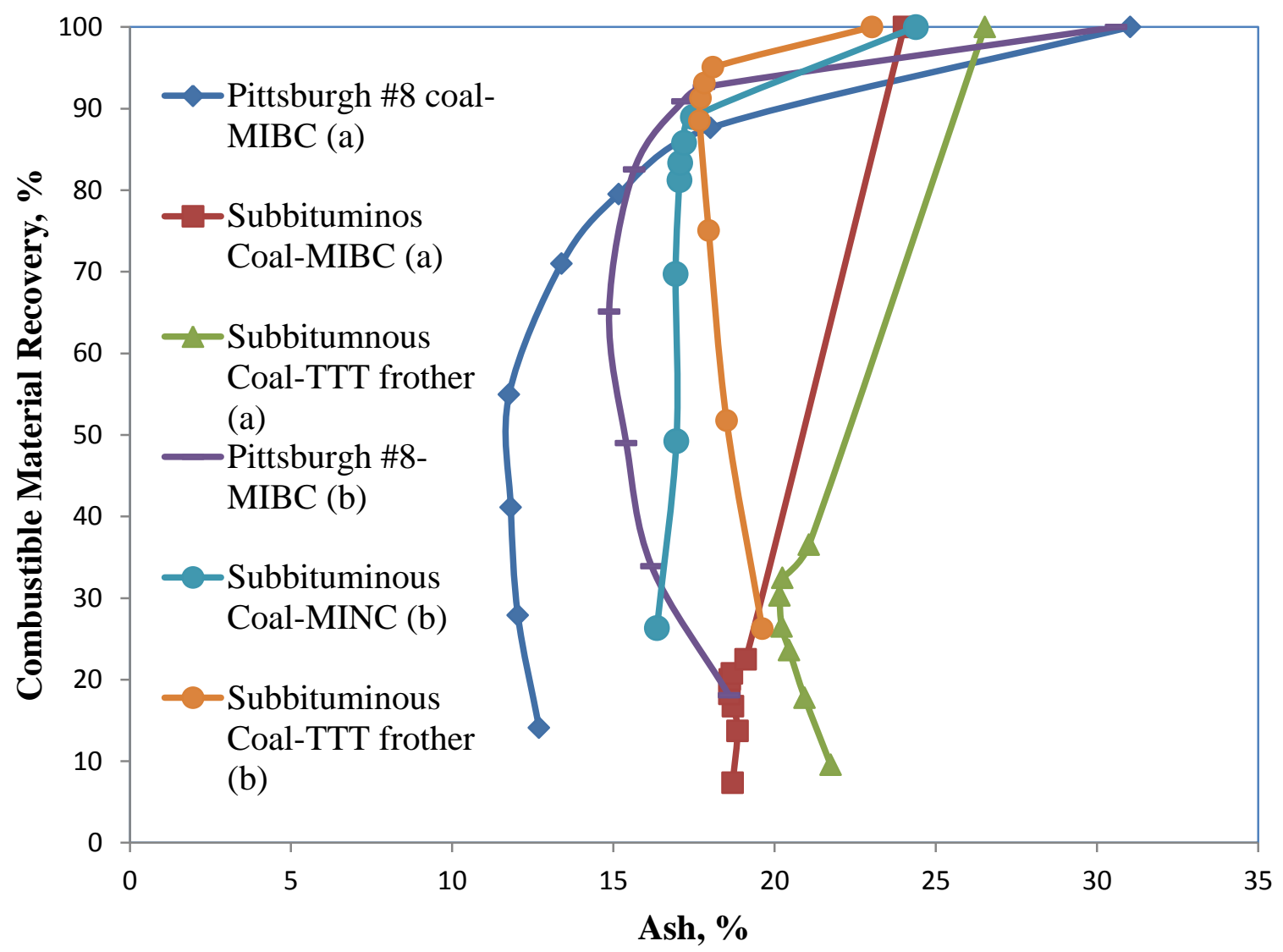

Figure 4-3 Combustible material recovery versus ash content (a) collector 0.5

$\mathrm{kg} / \mathrm{mt}$, frother $0.02 \mathrm{~kg} / \mathrm{mt}$, and (b) collector $2 \mathrm{~kg} / \mathrm{mt}$, frother $0.3 \mathrm{~kg} / \mathrm{mt}$.

From the results of these flotation experiments, the flotation of subbituminous coal using MIBC as frother obtained very low combustible material recovery. When the MIBC was replaced by the TTT frother at the same dosage, the cumulative combustible material recovery increased significantly. Compare the flotation of subbituminous coal and that of Pittsburgh \#8 coal (high volatile bituminous coal) which is known to have high floatability, combustible material recovery is much higher than the subbituminous coal using kerosene as collector and MIBC as frother. The results show reflects the subbituminous coal is a difficult to float coal. When the TTT frother is used in the semi-batch cell flotation, it can improve the combustible 
material recovery of subbituminous coal. It shows the TTT frother has better effect in recovering subbituminous coal.

In the second series of experiments, when the collector dosage is increased to 2 $\mathrm{kg} / \mathrm{mt}$ and frother is increased to $0.3 \mathrm{~kg} / \mathrm{mt}$, the combustible material recovery of these three experiments are above $85 \%$ with about $17.5 \%$ of clean coal ash content. These experiments prove that the use of high chemical reagents dosage can recover most of the coal particles from feed coal, however with higher clean coal ash content.

\subsection{Frother and Collector Effects for Stirred Tank Cell Flotation}

The chemical reagents used are kerosene as collector and MIBC as frother for subbituminous coal flotation. The overall low combustible material recovery and high ash content of clean coal shows the conventional flotation method cannot achieve satisfactory flotation results due to the nature oxidation of the subbituminous coal. Several stirred tank cell flotation tests were conducted on the coal sample (minus 250 $\mu \mathrm{m})$ by varying chemical reagent dosage. The subbituminous coal has naturally oxidized surface where the oxygenated functional groups have occupied many parts of coal surface. The chemical reagent must be increased to spread the collector and adsorb on the coal surface that improves its hydrophobicity. The experiment based on the variation of MIBC dosages from $0.02 \mathrm{~kg} / \mathrm{mt}$ to $0.3 \mathrm{~kg} / \mathrm{mt}$ while keeping the kerosene dosage constant at $0.5 \mathrm{~kg} / \mathrm{mt}$. In this experiment, the MIBC dosage was increased to float the difficult-to-float coal in order to enhance the hydrophobicity of coal fines. The flotation results of this series of stirred tank cell flotation are given in Table 4-4. 
Table 4-4 Results of stirred tank cell flotation using various MIBC dosages at 0.5 kg/mt kerosene.

\begin{tabular}{|c|c|c|c|c|c|c|c|}
\hline $\begin{array}{c}\text { MIBC, } \\
\mathrm{kg} / \mathrm{mt}\end{array}$ & $\begin{array}{c}\text { Clean } \\
\text { Coal, } \mathrm{g}\end{array}$ & $\begin{array}{c}\text { Tailings, } \\
\mathrm{g}\end{array}$ & $\begin{array}{c}\text { Clean } \\
\text { Coal, } \%\end{array}$ & $\begin{array}{c}\text { Tailings, } \\
\%\end{array}$ & $\begin{array}{c}\text { Clean Coal } \\
\text { Ash, } \%\end{array}$ & $\begin{array}{c}\text { Tailings } \\
\text { Ash, } \%\end{array}$ & $\begin{array}{c}\text { CMR, } \\
\%\end{array}$ \\
\hline 0.02 & 33.53 & 130.77 & 20.41 & 79.59 & 20.30 & 24.50 & 16.27 \\
\hline 0.08 & 51.65 & 114.47 & 31.09 & 68.91 & 20.23 & 24.40 & 24.80 \\
\hline 0.16 & 62.22 & 107.41 & 36.68 & 63.32 & 18.21 & 26.00 & 30.00 \\
\hline 0.3 & 58.88 & 111.13 & 34.63 & 65.37 & 18.70 & 25.00 & 28.16 \\
\hline
\end{tabular}

To present the changing trend of the combustible material recovery and clean coal ash content with the variation of the MIBC dosage, their relationship is plotted in Figure 4-4.

From the flotation results, the increasing of MIBC dosage can certainly improve the combustible material recovery and reduce the clean coal ash content. The increase of the combustible material recovery with increasing amount of MIBC dosage may be attributed to the positive effect of MIBC on the dispersion of kerosene over the coal surface especially those hydrophilic sites (Naik et al., 2005). In addition, the MIBC can also interact with the coal particles on the polar site of the coal surface through hydrogen bonding that increases the selectivity (Polat et al., 2003). Thus the hydrophobicity of the coal particles is enhanced. However, the MIBC on the combustible material recovery of this batch of subbituminous coal sample is limited. When the MIBC dosage was used more than $0.16 \mathrm{~kg} / \mathrm{mt}$, there exists the maximum value of combustible material recovery that was obtained. When the MIBC dosage was continuing increased, it reduced the recovery of clean coal particles. This phenomenon may be caused by the overdose of MIBC that coated on the coal surface that decreased the hydrophobicity of the coal particles (Naik et al., 2005). This means 
the combustible material recovery increases corresponding to the improved MIBC concentration that reflect coal particles become more hydrophobic and selective.

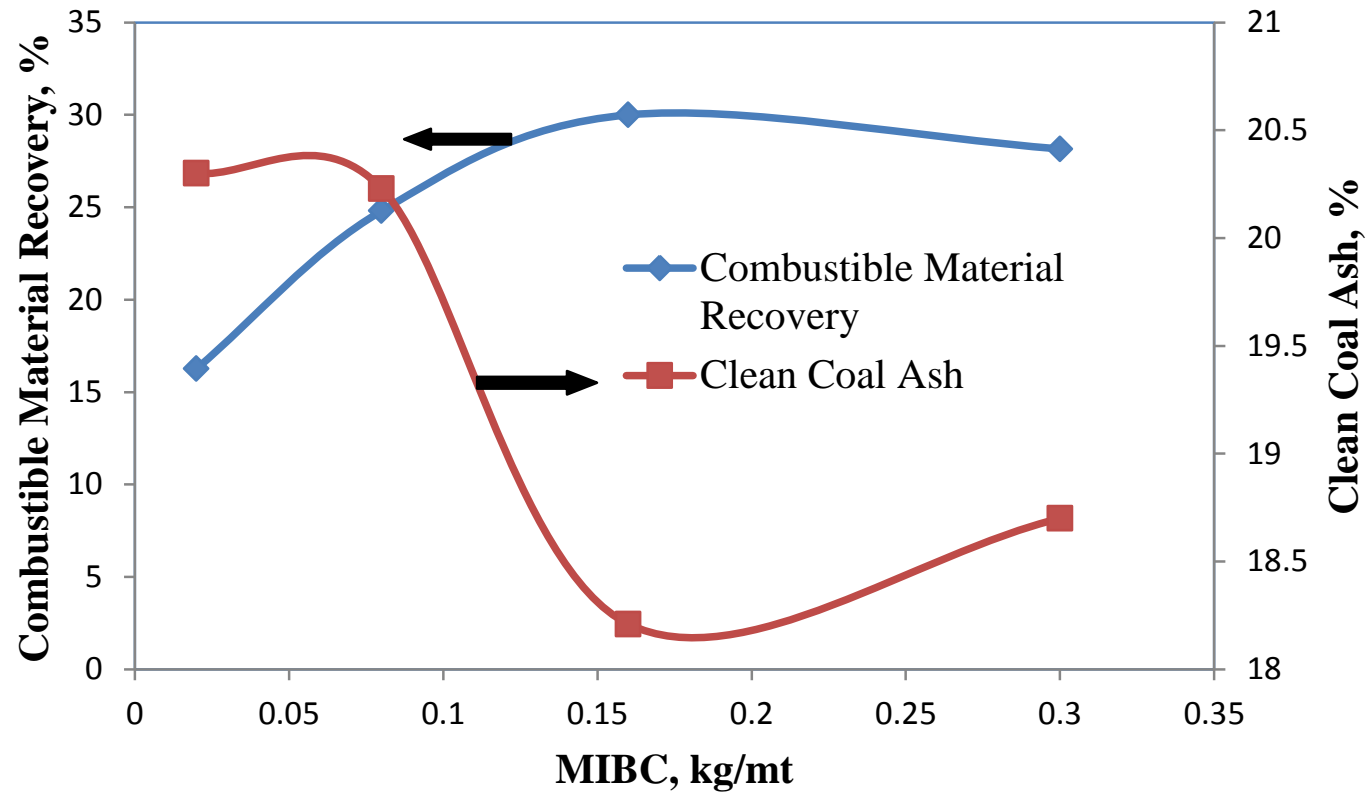

Figure 4-4 Combustible material recovery and clean coal ash versus MIBC dosage in the stirred tank cell flotation.

When the frother concentration increases, the surface tension of the interface between the water and air bubble becomes smaller which forms more stable and small air bubbles. Excessive amount of frother addition may lead to "stiff" frother, which may be harder to coalescence caused by the excessive interface surface tension. If the air bubbles size becomes smaller, its quantity will be larger with the constant air flow rate Thus the increased MIBC dosage also affects the flotation performance through its own effect.

The second set of stirred tank cell flotation tests applied on the coal is to test the effect of TTT frother on the difficult-to-float coal flotation performance. This aims to 
test whether the selected frother has the ability to activate the naturally oxidized subbituminous coal surface to become more hydrophobic and have better separation. The design of this set of stirred tank cell flotation test varies the TTT frother dosage from $0.02 \mathrm{~kg} / \mathrm{mt}$ to $0.3 \mathrm{~kg} / \mathrm{mt}$. The kerosene dosage in this series of experiments is constant at $0.5 \mathrm{~kg} / \mathrm{mt}$. The flotation results are shown in Table 4-5:

Table 4-5 Results of stirred tank cell flotation using various TTT frother dosages at $0.5 \mathrm{~kg} / \mathrm{mt}$ kerosene.

\begin{tabular}{|c|c|c|c|c|c|c|c|}
\hline $\begin{array}{c}\text { TTT frother, } \\
\mathrm{kg} / \mathrm{mt}\end{array}$ & $\begin{array}{c}\text { Clean } \\
\text { Coal, } \mathrm{g}\end{array}$ & $\begin{array}{c}\text { Tailings, } \\
\mathrm{g}\end{array}$ & $\begin{array}{c}\text { Clean } \\
\text { Coal, } \%\end{array}$ & $\begin{array}{c}\text { Tailings, } \\
\%\end{array}$ & $\begin{array}{c}\text { Clean Coal } \\
\text { Ash, } \%\end{array}$ & $\begin{array}{c}\text { Tailings } \\
\text { Ash, } \%\end{array}$ & $\begin{array}{c}\text { CMR, } \\
\%\end{array}$ \\
\hline 0.02 & 53.96 & 110.96 & 32.72 & 67.28 & 21.02 & 24.49 & 34.22 \\
\hline 0.08 & 92.09 & 72.06 & 56.10 & 43.90 & 16.75 & 31.46 & 68.14 \\
\hline 0.16 & 107 & 58.4 & 64.69 & 35.31 & 15.80 & 35.96 & 85.06 \\
\hline 0.3 & 118.21 & 49.77 & 70.37 & 29.63 & 15.40 & 37.83 & 95.76 \\
\hline
\end{tabular}

From the flotation results, the clean coal yield and combustible material are much higher than that produced by MIBC at the same dosage. In addition, the clean coal ash content decreases from $21 \%$ to $15.4 \%$, while combustible material recovery increases from $34.2 \%$ to $95.8 \%$ by increasing TTT frother dosage from $0.02 \mathrm{~kg} / \mathrm{mt}$ to $0.3 \mathrm{~kg} / \mathrm{mt}$, at $0.5 \mathrm{~kg} / \mathrm{mt}$ kerosene dosage. The significant effects on enhancing combustible material recovery and reduction of clean coal ash content are remarkable. Additionally, the blended frother with multiple key ingredients as surfactants can activate naturally oxidized surface of difficult to float coal. The combustible material recovery and clean coal ash content versus the TTT frother dosages is presented in Figure 4-5: 


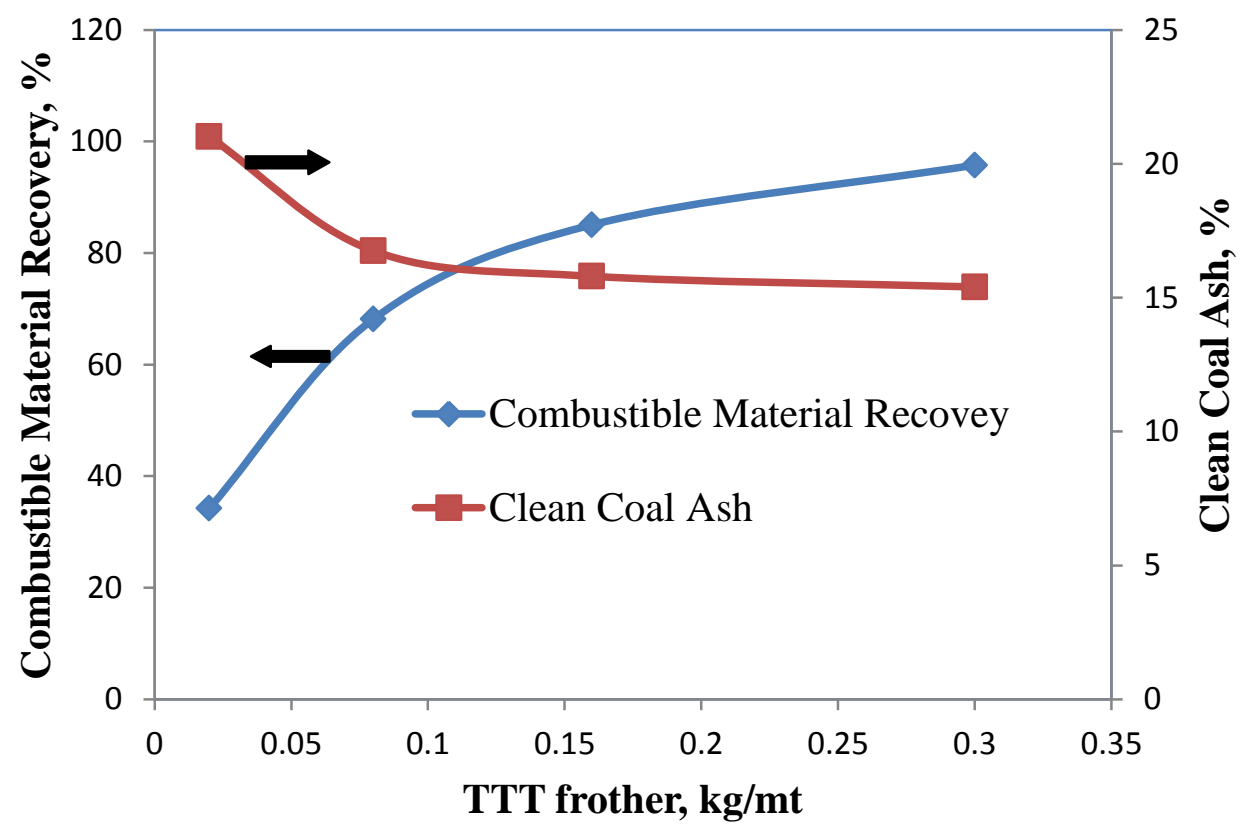

Figure 4-5 Combustible material recovery and clean coal ash versus the TTT frother dosage in stirred tank cell flotation.

Figure 4-5 shows the relationship between the TTT frother concentration and combustible material recovery and clean coal ash content. The TTT frother can reduce the interface surface tension and assist creating smaller and more stable air bubbles. The highest clean coal yield can reach $70.37 \%$ while the combustible material recovery at this frother concentration is $95.76 \%$. More important is the increasing of the clean coal yield with the decreasing of clean coal ash content as TTT frother dosage increased from 0.02 to $0.3 \mathrm{~kg} / \mathrm{mt}$. This means that the selected frother not only enhances the floatability of the coal particles, but also improves the selectivity of the subbituminous clean coal product. In comparing the MIBC at the highest combustible material recovery point, the increment of combustible material recovery is $56.75 \%$ combined with the reduction of clean coal ash content of $2.41 \%$. Therefore, it can be concluded that the TTT frother can improve the flotation of difficult-to-float coal both 
in the combustible material recovery and the clean coal quality.

Using the same air flow rate, the TTT frother can generate much smaller air bubbles than the MIBC. Thus the air bubble produced under TTT frother is more stable during flotation process that brings the fine particles to the froth layer. Compare the flotation result produced by MIBC and TTT frother at the same concentration, the TTT frother can obtain higher combustible material dosage with lower product ash content than MIBC, which means the TTT frother is better than the MIBC both in frothing ability and selectivity. In this subbituminous coal sample, about $30 \%$ coal particles have size smaller than $45 \mu \mathrm{m}$. The ash content of this fraction is $32 \%$. It is obvious there is a large quantity of clay materials in this size fraction that presents hydrophobic may also be brought to the froth layer through the entrainment effect. This may be the main reason contributed to the ash content being as high as $15 \%$ in clean coal product. In the column flotation, this problem can be overcome by spreading wash water over the froth layer to wash off the mineral particles in the froth layer brought to the froth layer by the entrainment effect.

The third series of stirred tank cell flotation is using the kerosene as the variable quantity to explain the collector effect on the flotation performance of this batch of subbituminous coal. In this series of experiments, the variation of the kerosene dosage between $0.5 \mathrm{~kg} / \mathrm{mt}$ and $2 \mathrm{~kg} / \mathrm{mt}$. The TTT frother concentration in these experiments is constant at $0.06 \mathrm{~kg} / \mathrm{mt}$.

Since subbituminous coal is naturally oxidized coal, it has oxygenated functional groups on the coal surface (Jia et al., 2000). Therefore the consumption of collector might be larger in the froth flotation to cover those oxidized surfaces to further improve the hydrophobicity of the coal particles. The results of this series of stirred 
tank cell flotation are presented in Table 4-6.

Table 4-6 Results of stirred tank cell flotation using kerosene as variable

\begin{tabular}{|c|c|c|c|c|c|c|c|}
\hline $\begin{array}{c}\text { Kerosene, } \\
\mathrm{kg} / \mathrm{mt}\end{array}$ & $\begin{array}{c}\text { Clean } \\
\text { Coal, } \mathrm{g}\end{array}$ & $\begin{array}{c}\text { Tailings, } \\
\mathrm{g}\end{array}$ & $\begin{array}{c}\text { Clean } \\
\text { Coal, } \%\end{array}$ & $\begin{array}{c}\text { Tailings, } \\
\%\end{array}$ & $\begin{array}{c}\text { Clean Coal } \\
\text { Ash, } \%\end{array}$ & $\begin{array}{c}\text { Tailings } \\
\text { Ash, \% }\end{array}$ & $\begin{array}{c}\text { CMR, } \\
\%\end{array}$ \\
\hline 0.5 & 63.9 & 110.06 & 36.73 & 63.27 & 20.86 & 30.34 & 29.07 \\
\hline 1 & 101.34 & 70.22 & 59.07 & 40.93 & 18.40 & 38.25 & 48.20 \\
\hline 1.5 & 120.85 & 49.36 & 71.00 & 29.00 & 16.47 & 46.13 & 59.31 \\
\hline 2 & 128.77 & 43.1 & 74.92 & 25.08 & 16.87 & 51.19 & 62.28 \\
\hline
\end{tabular}

The results show that the increase dosage of kerosene as collector has significant effect on the flotation performance of subbituminous coal in terms of clean coal ash content and combustible material recovery.

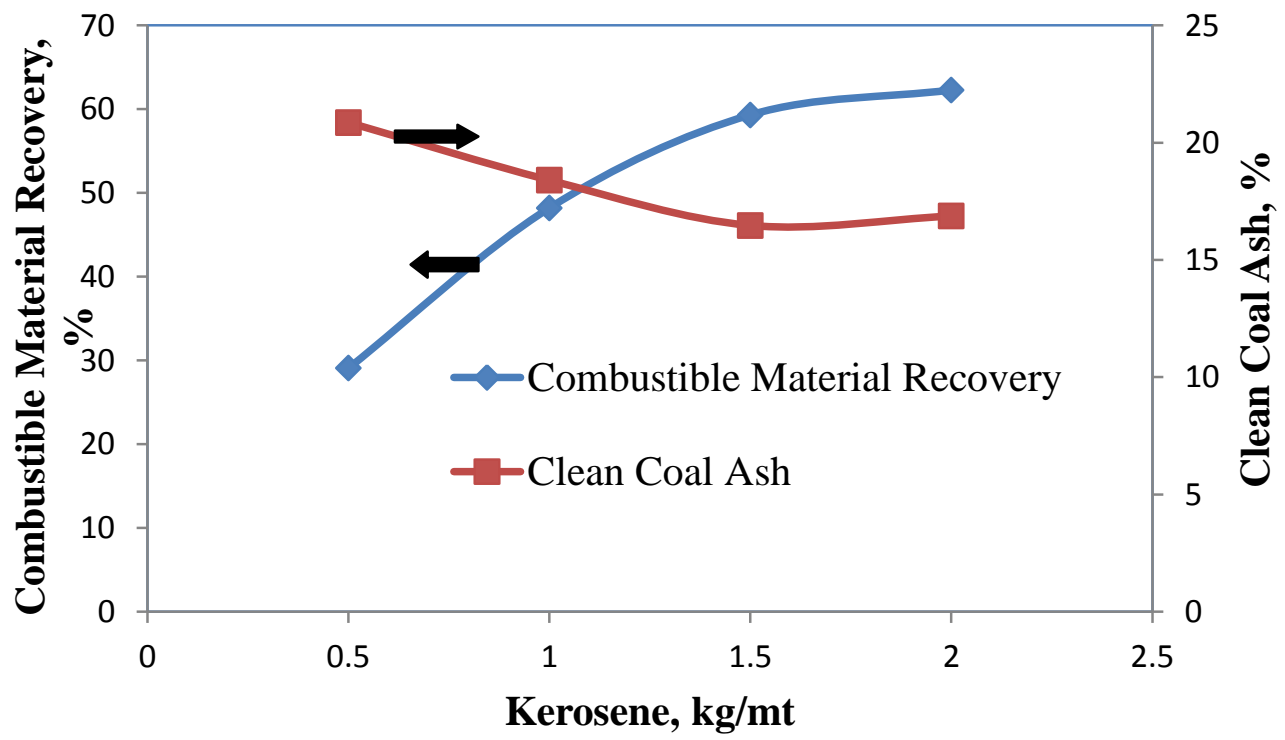

Figure 4-6 Combustible material recovery and clean coal ash versus kerosene dosage in stirred tank cell flotation.

From these tests results, the combustible material recovery increases with the enhanced consumption of the collector dosage. The highest combustible material recovery reaches $81 \%$ which uses four times the amount of kerosene used of 0.5 $\mathrm{kg} / \mathrm{mt}$ for the flotation of good to float coal. This is in agreement with previous studies 
of the effect of kerosene. This shows the collector has dramatically increased the hydrophobicity of coal particles that improves the combustible material recovery. However, it can create tendency of overly used oily collector. When the amount of kerosene is $2 \mathrm{~kg} / \mathrm{mt}$, the clean coal product ash is higher than the kerosene dosage of $1.5 \mathrm{~kg} / \mathrm{mt}$. From this, the kerosene is inferred to be overused at $2 \mathrm{~kg} / \mathrm{mt}$. Though oil collector improved the hydrophobicity of coal particles, it might also modify the surface property of other mineral particles that made them easier to float. This may be the main reason that caused the clean coal ash content becomes higher when kerosene used at $2 \mathrm{~kg} / \mathrm{mt}$. Therefore the amount of kerosene used should be controlled to not be overused for the production of high quality clean coal.

\subsection{Column Flotation Using Pico and Nano Bubbles}

The flotation column can use its advantages to further improve the flotation efficiency of difficult-to-float coal. Though the open flotation column does not have any mechanical part applied during the flotation process, it has long flotation region

and wash water system which improve the clean coal quality. Especially the newly developed pico and nano bubble generation system designed for the revised open flotation column. These tiny air bubbles are retained in the flotation column much longer and dramatically enhance the probabilities of collision and attachment between air bubble and coal particles.

To operate the flotation column, six factors are considered that affect the flotation result most significantly. They are: 

(1) Feed Solid Concentration
(2) Collector Dosage
(3) Frother Dosage
(4) Air Flow Rate
(5) Feed Rate
(6) Wash Water Rate

The feed rate and feed solid concentration affect the processing capacity per unit time. If the dry coal processing amount exceeds the processing capacity of the column, more clean coal will be disposed through the tailings stream. If this amount processed becomes too low, it not only increases the time cost and energy cost, but also reduces the clean coal quality. The collector dosage and frother dosage are the chemical reagent factors that related to the flotation results. The effects of properties, dosage, and interaction characteristics of chemical reagents on the surface of coal particles related to the flotation performance. If the amount of reagents used is too low, it cannot improve the coal surface property to the extent that improves the flotation results. If the reagent dosage is too high, it will exert reverse effect on the coal surface that makes it become hydrophilic and modify the surface of mineral particles to become hydrophobic. At the same time this will make hydrophilic mineral particles become hydrophobic particles due to the excessive amount of reagents. In present study, TTT frother is employed instead of conventional frother such as MIBC to study its effect on the subbituminous coal, a difficult-to-float coal, which shows high degree of hydrophilicity.

The wash water rate determines how effective it can remove the entrained 
ultrafine mineral particles in the froth layer (Finch, 1995). This efficiency related with the froth layer height, air bubble property and the adsorption conditions between the solid particles and air bubbles. Varying the wash water rate in the design of experiment can find out the best wash water flowing rate according to the property of froth layer and coal sample.

The air flow rate affects the bubble generation. As the schematic of the air bubble generation system described in Chapter 3, the air is fed into the tailings stream from the inner funnel before entering the peristaltic pump. The air-slurry ratio is determined by the tailings slurry volume drawn out per unit time and the air flow rate. The mixture of tailings slurry and air passes through a static mixer and then a venturi cavitation tube. The air volume percent in the air-slurry mixture controls the pico and nano bubble size distributions. If the air volume is too high, it causes too little slurry passing through the venturi cavitation tube that cannot provide enough water to break the air flow into tiny air bubbles and maintain their tiny size before entering the flotation column. If the air flow rate is too low, when the mixture passes through the venturi cavitation tube, it does not have enough air to be disparaged. Only a small quantity of tiny bubbles can be produced. The air bubble generation system affected by the tailings stream solid concentration, air percentage and volume flow rate, as well as the dimensions of venture cavitation tube. The peristaltic pump speed has been adjusted to the rate that can create the appropriate percentages of pico and nano bubbles distributions, when using the water, air and $0.02 \mathrm{~kg} / \mathrm{mt} \mathrm{MIBC}$ in the initial test. The detailed optimal of venture cavitation tube for generating pico and nano bubbles and measurement of bubble distributions will be reported by peng and xiong (2014). For the column flotation initial test, the tailings recirculating stream has solid 
particles. Therefore the air flow rate is varied to optimize it according to the experiment conditions.

Based on the semi-batch cell flotation results for subbituminous coal, the column flotation test based on six factors is designed, which is exhibited in Table 4-7. The ranges of three levels for each factor are given in Talbe 4-8. In this design of experiment, the custom design in JMP software tool (SAS Institution) is employed which using the I-optimal design. Trials in the I-optimal design are well spread out from each other. In comparing with the classic designs, the I-optimal design spread the points out to provide the minimum average variance of predictions rather than spread the points out in space. This design is most cost-effective, and it can minimize the average variance of prediction over the factor space. The variance is the square of the standard deviation of the prediction from the fitted model (Kappele, 1998).

The first stage design of experiment can be used to analyze the effect of each factor on the flotation performance. By analyzing the flotation results, it can provide which factors are more significant in the froth flotation process. Additionally, the coefficient among these factors can also be analyzed. The flotation results of this set of column flotation experiments are shown in Table A-1.

Combustible material recovery is an important standard to check the efficient the froth flotation performance. High combustible material recovery represents the coal particles in the raw coal can be recovered efficiently, while low combustible material recovery means many of the coal particles are lost to the tailings stream. Therefore, high combustible material recovery is the major purpose in conducting the froth flotation. Despite the achievement on the combustible material recovery, the clean coal, product, quality must be considered. Because the lower the ash content of the 
clean coal, the higher the unit price it will be. To analyze the correlation between the operating parameters and the responses, the statistical analysis method is applied for data reduction and interpretation.

Table 4-7 Fractional factorial design of experiment for column flotation tests using 6 factors

\begin{tabular}{|c|c|c|c|c|c|c|}
\hline $\begin{array}{c}\text { Experiment. } \\
\text { No. }\end{array}$ & $\begin{array}{c}\text { Feed Solid } \\
\text { Concentration }\end{array}$ & $\begin{array}{c}\text { Collector } \\
\text { Dosage }\end{array}$ & $\begin{array}{c}\text { Frother } \\
\text { Dosage }\end{array}$ & $\begin{array}{c}\text { Air Flow } \\
\text { Rate }\end{array}$ & $\begin{array}{c}\text { Wash Water } \\
\text { Rate }\end{array}$ & $\begin{array}{c}\text { Feed } \\
\text { Rate }\end{array}$ \\
\hline 1 & + & - & 0 & - & 0 & + \\
\hline 2 & 0 & - & - & + & + & + \\
\hline 3 & - & - & + & 0 & + & 0 \\
\hline 4 & - & 0 & 0 & + & 0 & - \\
\hline 5 & 0 & - & 0 & 0 & - & + \\
\hline 6 & - & - & - & + & 0 & 0 \\
\hline 7 & 0 & + & + & - & + & + \\
\hline 8 & + & 0 & + & 0 & 0 & + \\
\hline 9 & 0 & 0 & + & + & - & - \\
\hline 10 & 0 & + & - & 0 & 0 & 0 \\
\hline 11 & - & + & + & + & 0 & + \\
\hline 12 & + & + & - & + & - & + \\
\hline 13 & - & - & - & - & - & - \\
\hline 14 & - & + & 0 & 0 & + & - \\
\hline 15 & - & + & + & - & - & 0 \\
\hline 16 & + & - & 0 & + & + & 0 \\
\hline 17 & - & 0 & 0 & - & + & + \\
\hline 18 & + & - & + & 0 & - & - \\
\hline 19 & + & + & 0 & + & - & 0 \\
\hline 20 & 0 & 0 & 0 & 0 & - & 0 \\
\hline 21 & - & 0 & - & 0 & - & + \\
\hline 22 & 0 & + & 0 & - & 0 & - \\
\hline 23 & + & 0 & - & - & + & 0 \\
\hline 24 & + & + & - & 0 & + & - \\
\hline & & & & & & + \\
\hline
\end{tabular}


Table 4-8 Ranges of three levels for the first stage design of experiment using 6

factors

\begin{tabular}{|c|c|c|c|c|c|c|}
\hline & $\begin{array}{c}\text { Feed Solid } \\
\text { Concentration, \% }\end{array}$ & $\begin{array}{c}\text { Collector } \\
\text { Dosage, } \\
\mathrm{kg} / \mathrm{mt}\end{array}$ & $\begin{array}{c}\text { Frother } \\
\text { Dosage, } \\
\mathrm{kg} / \mathrm{mt}\end{array}$ & $\begin{array}{c}\text { Air Flow } \\
\text { Rate,cm/s }\end{array}$ & $\begin{array}{c}\text { Wash } \\
\text { Water Rate, } \\
\mathrm{cm} / \mathrm{s}\end{array}$ & $\begin{array}{c}\text { Feed } \\
\text { Rate, } \\
\mathrm{cm} / \mathrm{s}\end{array}$ \\
\hline+ & 10 & 1 & 0.12 & $1.125 \mathrm{~cm} / \mathrm{s}$ & 0.138 & 0.53 \\
\hline 0 & 6 & 0.6 & 0.08 & $0.75 \mathrm{~cm} / \mathrm{s}$ & 0.092 & 0.43 \\
\hline- & 3 & 0.3 & 0.05 & $0.375 \mathrm{~cm} / \mathrm{s}$ & 0.046 & 0.33 \\
\hline
\end{tabular}

The combustible material recovery and the clean coal ash content are chosen as the responses respectively. The ANOVA Table and the Effect Tests Table of the factors on the flotation performance are shown in Table 4-9 and Table 4-10:

The ANOVA table shows the model composed of those six factors has the F ratio of 21.07 and its P-value is smaller than 0.0001 . The results show these six factors have significant correlation with the response of combustible material recovery from the column flotation performance results.

The data of ash content in the ANOVA table shows the model composed of these six factors cannot predict the clean coal product ash as precisely as they predict the combustible material recovery. From the effect tests result, the feed solid concentration has the lowest $\mathrm{P}$ value, this strongly means the feed solid concentration affect the combustible material recovery most. The $\mathrm{P}$ value of collector dosage and the frother dosage are 0.1046 and 0.0248 respectively. Those three factors have much lower P values than the other three factors. Therefore it can be inferred that Feed Solid Concentration, Collector Dosage and Frother Dosage are comparatively significant factors on the combustible material recovery for the flotation of subbituminous coal. 
Table 4-9 Analysis of Variance table for the first stage design of experiment.

\begin{tabular}{|c|c|c|c|c|}
\hline \multicolumn{5}{|c|}{ Combustible material recovery } \\
\hline Source & $\mathrm{DF}$ & Sum of Squares & Mean Square & F Ratio \\
\hline Model & 6 & 7220 & 1203.4 & 21.07 \\
\hline Error & 17 & 970.8 & 57.11 & Prob $>F$ \\
\hline C. Total & 23 & 8191 & & $<0.0001$ \\
\hline \multicolumn{5}{|c|}{ Ash Content } \\
\hline Source & DF & Sum of Squares & Mean of Square & F Ratio \\
\hline Model & 6 & 28.85 & 4.81 & 0.84 \\
\hline Errer & 17 & 97.74 & 5.75 & Prob $>F$ \\
\hline C. Total & 23 & 126.59 & & 0.5587 \\
\hline
\end{tabular}

Table 4-10 Effect Tests table for the first stage design of experiment.

\begin{tabular}{|c|c|c|c|c|c|}
\hline \multicolumn{6}{|c|}{ Combustible Material Recovery } \\
\hline Source & Nparm & $\mathrm{DF}$ & Sum of Squares & F Ratio & Prob>F \\
\hline Feed Solid Concentration & 1 & 1 & 6392.3 & 111.9 & $<0.0001$ \\
\hline Collector Dosage & 1 & 1 & 167.8 & 2.94 & 0.1046 \\
\hline Frother Dosage & 1 & 1 & 345.9 & 6.06 & 0.0248 \\
\hline Air Flow Rate & 1 & 1 & 6.35 & 0.11 & 0.743 \\
\hline Wash Water Rate & 1 & 1 & 4.6 & 0.08 & 0.78 \\
\hline Feed Rate & 1 & 1 & 27.4 & 0.48 & 0.498 \\
\hline \multicolumn{6}{|l|}{ Ash Content } \\
\hline Source & Nparm & $\mathrm{DF}$ & Sum of Squares & F Ratio & Prob>F \\
\hline Feed Solid Concentration & 1 & 1 & 6.69 & 1.164 & 0.296 \\
\hline Collector Dosage & 1 & 1 & 10.08 & 1.753 & 0.203 \\
\hline Frother Dosage & 1 & 1 & 0.05 & 0.009 & 0.925 \\
\hline Air Flow Rate & 1 & 1 & 0.0003 & 0.0001 & 0.994 \\
\hline Wash Water Rate & 1 & 1 & 0.389 & 0.0676 & 0.798 \\
\hline Feed Rate & 1 & 1 & 11.26 & 1.958 & 0.18 \\
\hline
\end{tabular}


Based on this series of column flotation experiments, the effect of operating factors on the clean coal ash content can also be analyzed. When the ash content of clean coal is chosen as the response, the solid concentration, collector dosage and feed rate are the comparatively significant parameters. In the operation ranges of these three factors, they affect the clean coal ash content more dramatically than the other three parameters on their operation ranges during the column flotation

The purpose of this study is to obtain the best quality clean coal with the combustible material recovery as high as possible. Therefore the three factors that affect the clean coal ash content more significantly will be chosen in further studies. To present the effect of solid concentration, collector dosage and feed rate on the clean coal ash and the combustible material recovery, response surface plot and contour plot based on the combination of every two factors of these three factors are given in Figure 4-7, Figure 4-8 and Figure 4-9 respectively. 
(a)
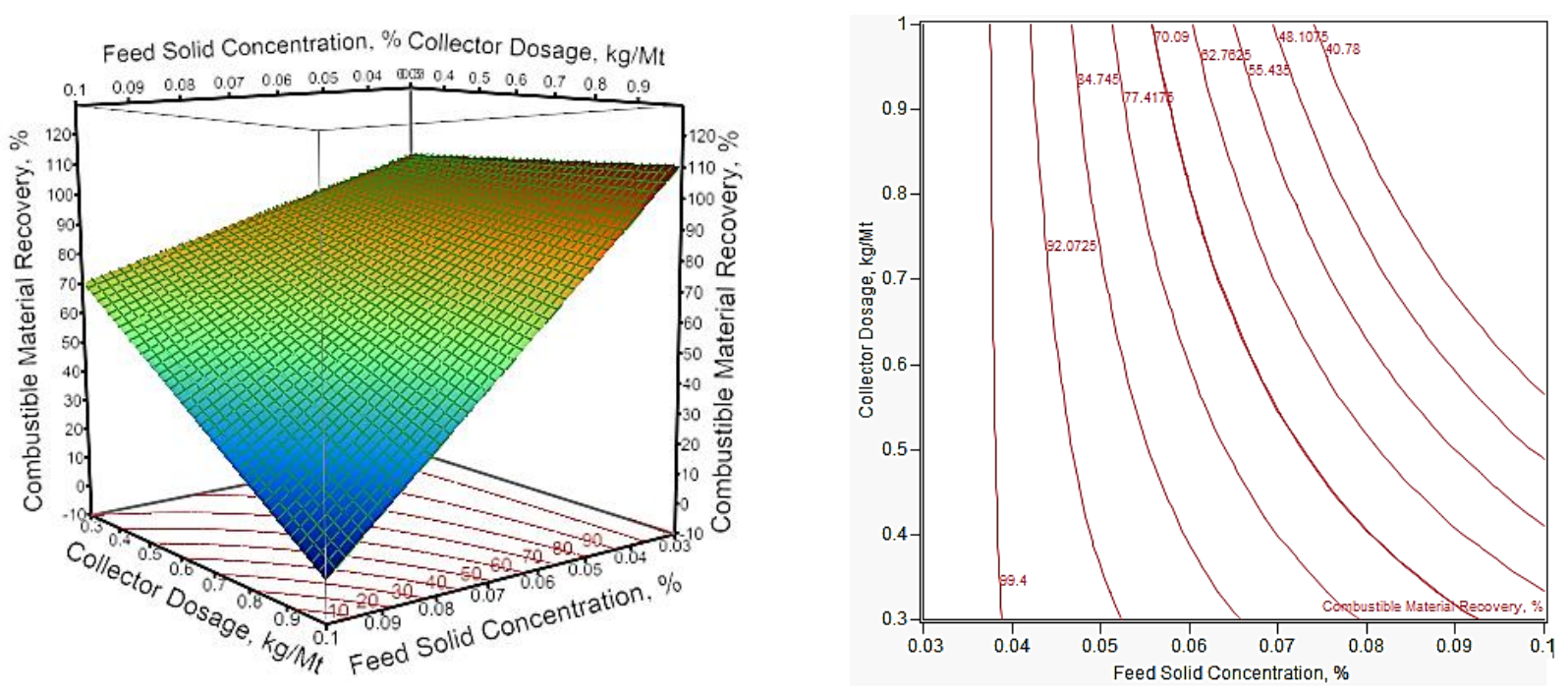

(b)
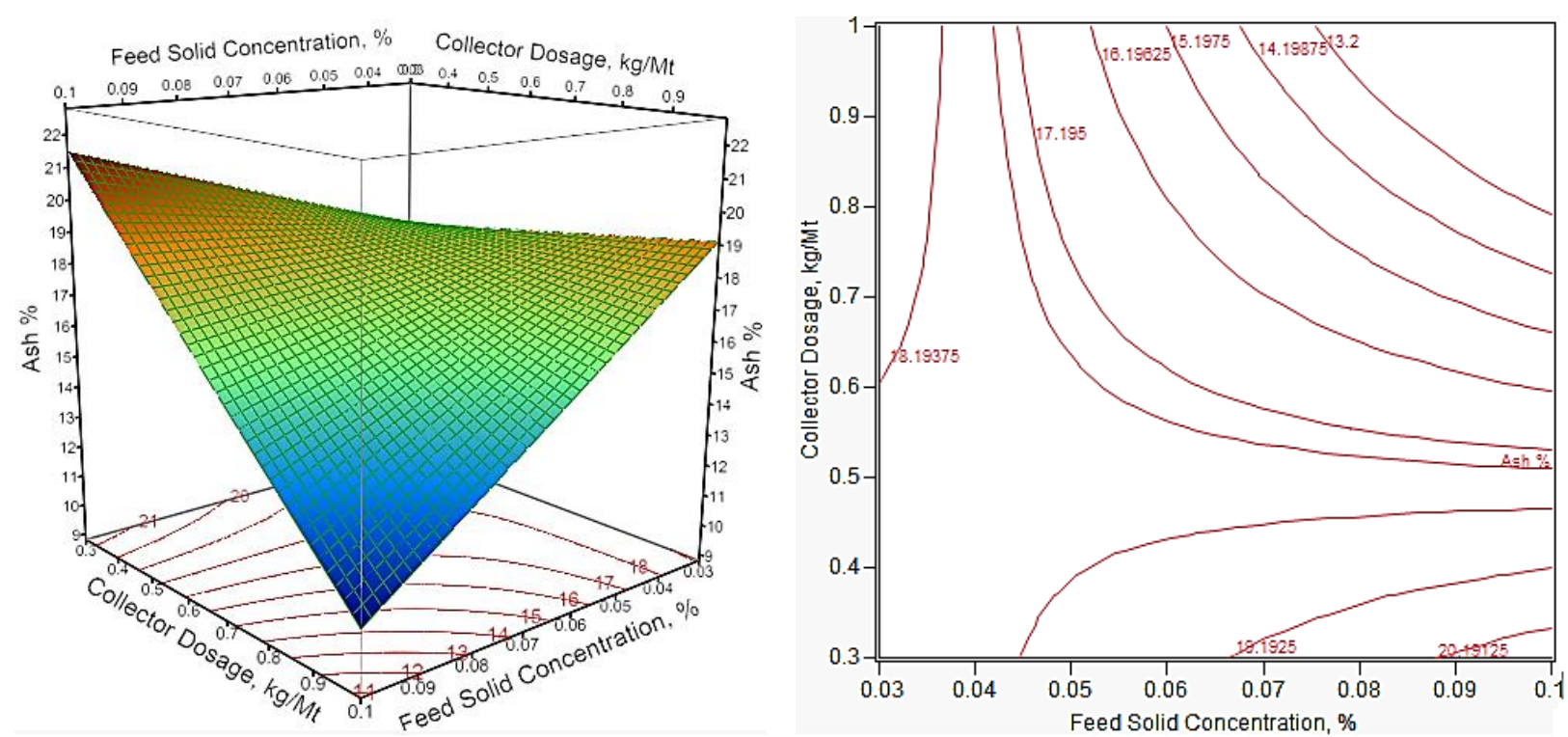

Figure 4-7 Effect of feed solid concentration and collector dosage on (a) the combustible material recovery and (b) clean coal ash. 
(a)
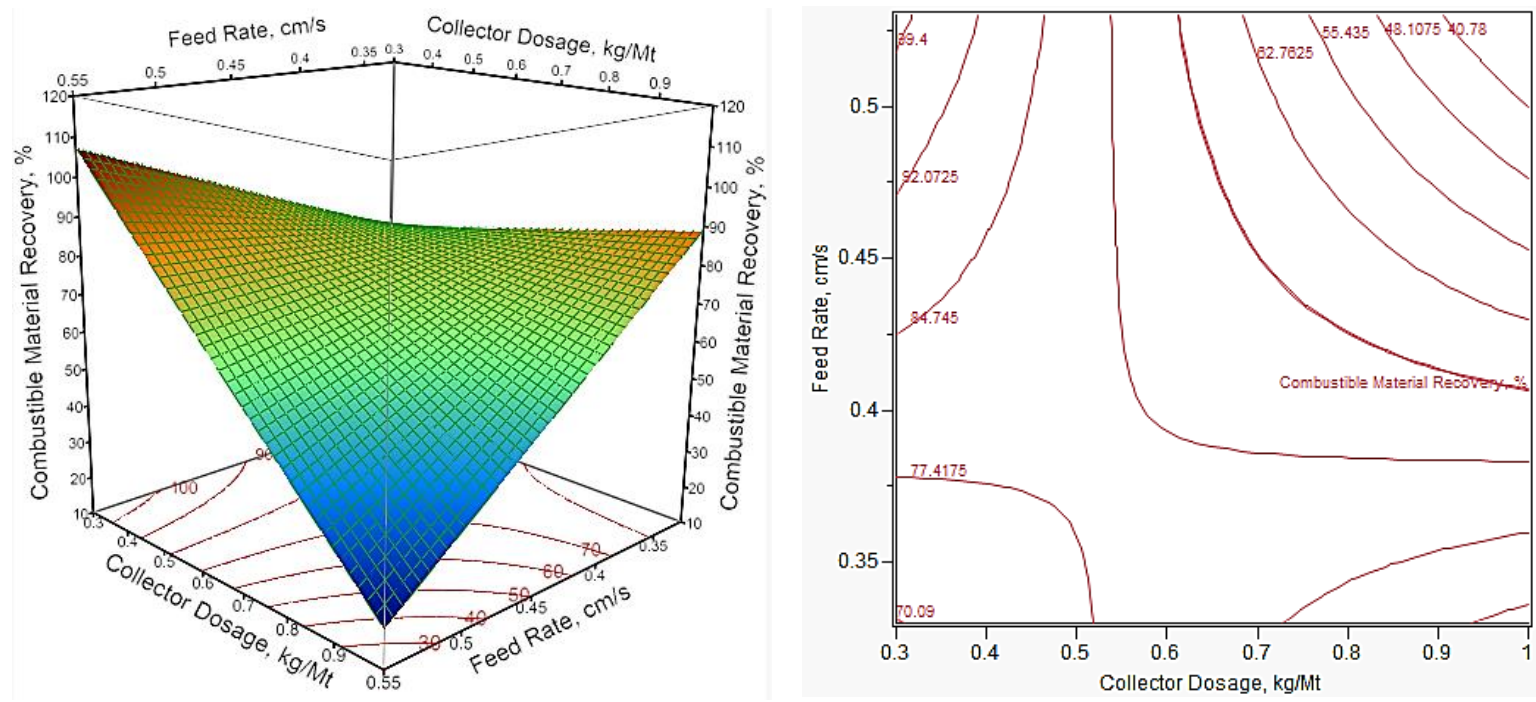

(b)
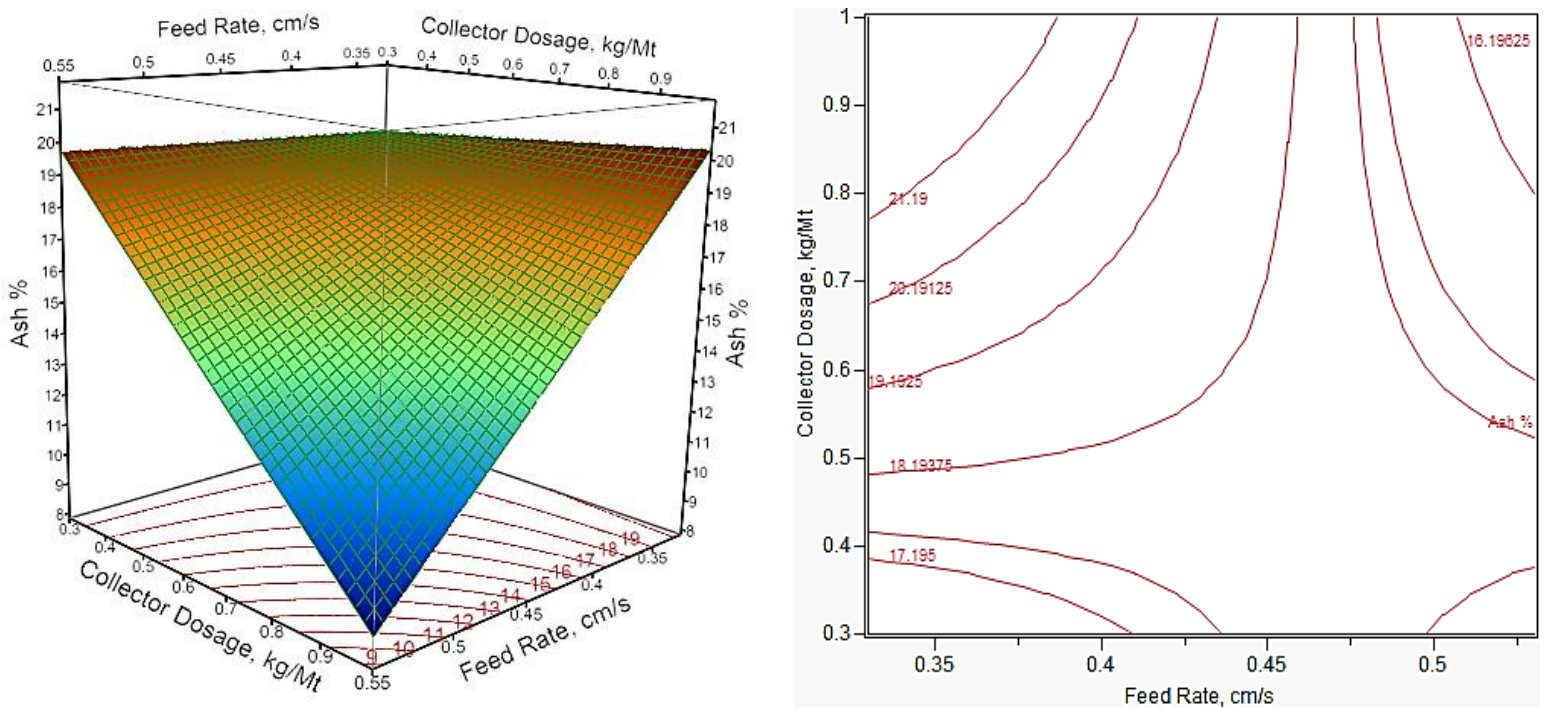

Figure 4-8 Effect of collector dosage and feed rate on (a) the combustible material recovery and (b) clean coal ash. 
(a)
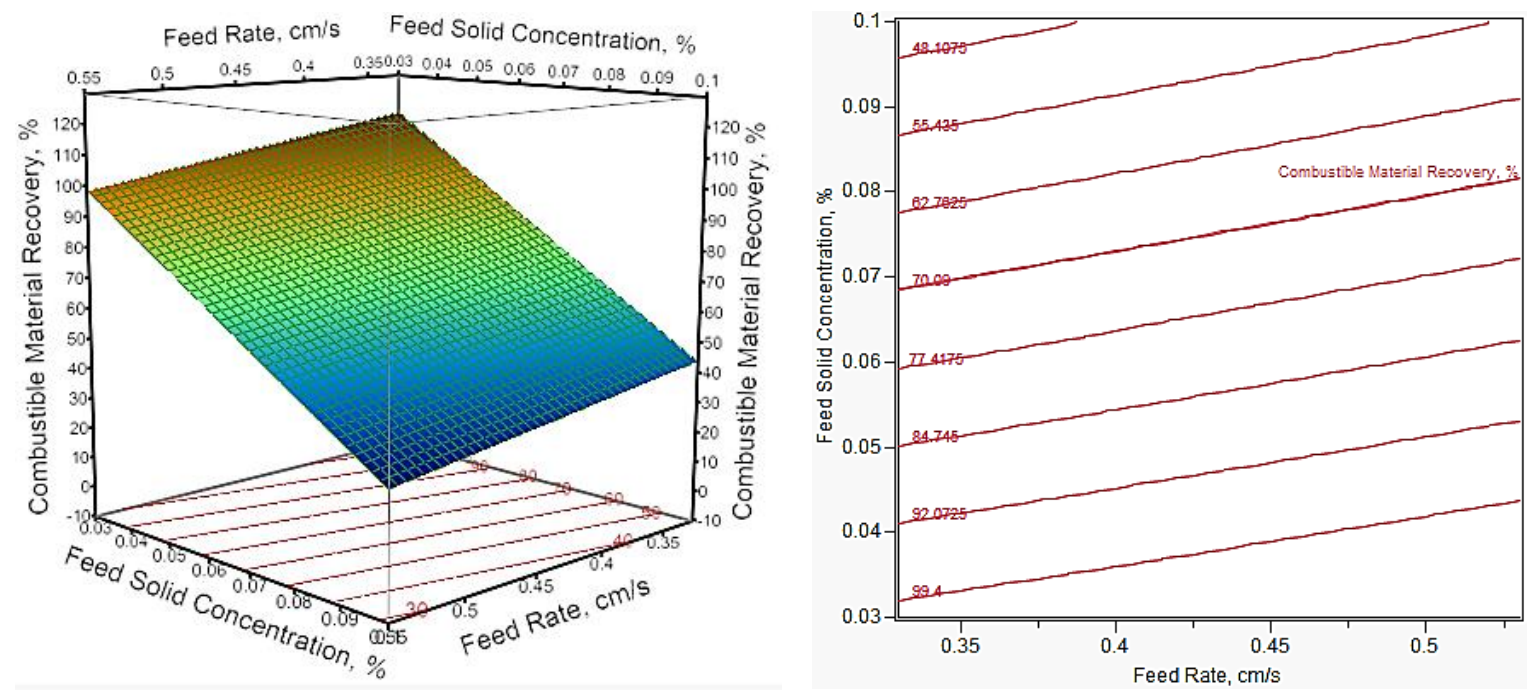

(b)
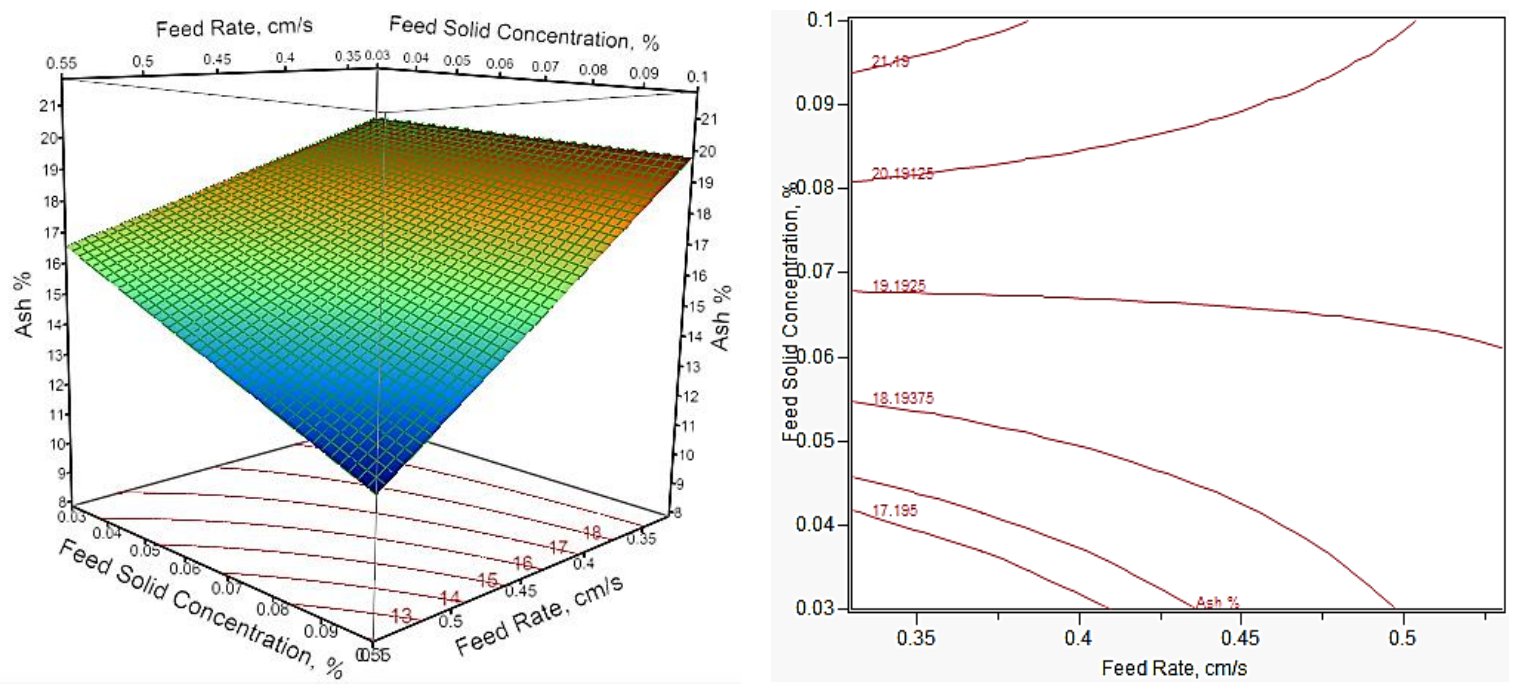

Figure 4-9 Effect of feed rate and feed solid concentration on (a) the combustible material recovery and (b) clean coal ash. 
Based on these $3 \mathrm{D}$ response surface plots, it can be inferred that the combustible material recovery can be in a high level when the feed solid concentration is comparatively low, feed rate is in low level and the collector dosage is in the middle level in its range. Additionally the clean coal ash content tends toward lower level when the collector dosage is high, while the feed solid concentration stays in the medium level and the feed rate keeps at a comparatively low level. For these three operating paramteres, the clean coal ash content is superior to the combustible material recovery to achieve the high quality coal. Therefore according to the clean coal ash content variation trend, a second stage of design of experiments is designed by varying those three significant factors in affecting the clean coal ash content around their best levels to obtain lower ash content of clean coal product. The purpose is to obtain high quality of clean coal product combined with the combustible material recovery as high as possible.

In addition to the effect of a single factor, the interactions between two of those six combinations on combustible material recovery and clean coal ash content are also considered. The effect test results for those factors combinations are shown in Table 4-11. The explanation for three factors in interaction is given in Table 4-12.

From the effect test results, the combinations of feed solid concentration $\times$ feed rate, collector dosage $\times$ air flow rate and collector dosage $\times$ wash water rate are comparatively significant than the other combinations effect on the clean coal ash content since these three combinations have $\mathrm{P}$ value smaller than 0.5 . While the interactions of feed solid concentration $\times$ feed rate, collector dosage $\times$ air flow rate, collector dosage $\times$ wash water rate, collector dosage $\times$ feed rate, and frother dosage $\times$ air flow rate are significant for the combustible material recovery. Thus, 
these interactions are incorporated into the prediction of combustible material recovery and clean coal ash content models as shown in Eq (4-1) and Eq (4-2) respectively.

Combustible material recovery $\%=93.76-580.2 \times \mathrm{A}-5.64 \times \mathrm{B}+0.22 \times$ $C+0.11 \times D-0.05 \times E+0.01 \times F+[(A-0.062) \times(E-3.92) \times 44.8]+$ $[(B-1.3) \times(D-40.83) \times 0.41]+[(B-3.92) \times(E-3.92) \times 4.14]+$ $[(B-1.3) \times(F-458.33) \times(-0.08)]+[(C-81.67) \times(D-40.83) \times$ $(-0.0094)]$

Clean Coal Ash $\%=11.6+15.88 \times A+1.09 \times B+0.003 \times C-0.007 \times D+$ $0.13 \times \mathrm{E}+0.007 \times \mathrm{F}+[(\mathrm{A}-0.06) \times(\mathrm{F}-458.33) \times 0.02]+[(\mathrm{B}-1.3) \times$ $(\mathrm{D}-40.83) \times 0.03]-[(\mathrm{B}-1.3) \times(\mathrm{E}-3.92) \times 0.33]$

Where A is Feed Solid Concentration; B is Collector Dosage; C is Frother Dosage; $\mathrm{D}$ is Air Flow Rate; E is Wash Water Rate; and F is Feed Rate 
Table 4-11 Effect Tests table of the combinations of each two factors for the first stage design of experiment.

\begin{tabular}{|c|c|c|c|c|c|c|}
\hline & \multicolumn{2}{|c|}{ Combustible Material Recovery } & \multicolumn{3}{c|}{ Clean Coal Ash Content } \\
\hline Source & Sum of Squares & F Ratio & Prob>F & Sum of Squares & F Ratio & Prob $>$ F \\
\hline $\mathrm{A} \times \mathrm{B}$ & 44.65 & 0.83 & 0.51 & 1.22 & 0.26 & 0.66 \\
\hline $\mathrm{A} \times \mathrm{C}$ & 79.25 & 1.11 & 0.4 & 1.62 & 0.34 & 0.62 \\
\hline $\mathrm{A} \times \mathrm{D}$ & 31.13 & 0.44 & 0.58 & 0.24 & 0.05 & 0.84 \\
\hline $\mathrm{A} \times \mathrm{E}$ & 96.16 & 1.35 & 0.37 & 1.34 & 0.28 & 0.65 \\
\hline $\mathrm{A} \times \mathrm{F}$ & 1.38 & 0.019 & 0.9 & 5.45 & 1.15 & 0.4 \\
\hline $\mathrm{B} \times \mathrm{C}$ & 59.04 & 0.83 & 0.44 & 0.05 & 0.01 & 0.93 \\
\hline $\mathrm{B} \times \mathrm{D}$ & 129.81 & 1.82 & 0.31 & 4.56 & 0.96 & 0.43 \\
\hline $\mathrm{B} \times \mathrm{E}$ & 87.78 & 1.23 & 0.38 & 6.1 & 1.28 & 0.38 \\
\hline $\mathrm{B} \times \mathrm{F}$ & 106.75 & 1.49 & 0.35 & 1.34 & 0.28 & 0.65 \\
\hline $\mathrm{C} \times \mathrm{D}$ & 96.11 & 1.34 & 0.37 & 2.85 & 0.6 & 0.52 \\
\hline $\mathrm{C} \times \mathrm{E}$ & 2.83 & 0.04 & 0.86 & 0.2 & 0.04 & 0.86 \\
\hline $\mathrm{C} \times \mathrm{F}$ & 15.43 & 0.22 & 0.69 & 0.78 & 0.16 & 0.72 \\
\hline $\mathrm{D} \times \mathrm{E}$ & 58.66 & 0.82 & 0.46 & 1.47 & 0.31 & 0.63 \\
\hline $\mathrm{D} \times \mathrm{F}$ & 72.59 & 1.02 & 0.42 & 1.96 & 0.41 & 0.59 \\
\hline $\mathrm{E} \times \mathrm{F}$ & 49.89 & 0.98 & 0.43 & 0.04 & 0.008 & 0.94 \\
\hline
\end{tabular}

Table 4-12 Explanations for the factors in interaction.

\begin{tabular}{|c|c|c|c|}
\hline Feed Solid Concentration & A & Collector Dosage & B \\
\hline Frother Dosage & C & Air Flow Rate & D \\
\hline Wash Water Rate & E & Feed Rate & F \\
\hline
\end{tabular}


After the analysis of the first stage of design of experiment for column flotation, the second stage of design of experiment uses feed rate, collector dosage and feed solid concentration as the variable factors. Despite these three variable factors, the other three factors are fixed during the column flotation. Frother dosage is $0.12 \mathrm{~kg} / \mathrm{mt}$, air flow rate is $0.75 \mathrm{~cm} / \mathrm{s}$ and wash water rate is $0.092 \mathrm{~cm} / \mathrm{s}$. The second stage design of experiment for the three levels of each factor is shown in Table 4-13. The ranges of three levels for the second stage design of experiment are given in Table 4-14.

Table 4-13 Second stage of design of experiments using 3 factors.

\begin{tabular}{|c|c|c|c|}
\hline Experiment. No. & Feed Solid Concentration & Collector Dosage & Feed Rate \\
\hline 1 & 0 & - & - \\
\hline 2 & + & - & + \\
\hline 3 & - & - & 0 \\
\hline 4 & - & + & + \\
\hline 5 & - & 0 & - \\
\hline 6 & 0 & + & 0 \\
\hline 7 & + & 0 & 0 \\
\hline 8 & + & + & - \\
\hline 9 & 0 & 0 & + \\
\hline
\end{tabular}

Table 4-14 Ranges of three levels for the second stage design of experiment using three factors.

\begin{tabular}{|c|c|c|c|}
\hline & Feed Solid Concentration, $\%$ & Collector Dosage, $\mathrm{kg} / \mathrm{mt}$ & Feed Rate, $\mathrm{cm} / \mathrm{s}$ \\
\hline+ & 6 & 0.75 & 0.38 \\
\hline 0 & 5 & 0.6 & 0.35 \\
\hline- & 4 & 0.45 & 0.30 \\
\hline
\end{tabular}


For this set of design of experiments, the feed solid concentration range is set between $4 \%$ and $6 \%$. The collector dosage changes from 0.45 to $0.75 \mathrm{~kg} / \mathrm{mt}$ and the feed rate varying from $836 \mathrm{ml} / \mathrm{min}$ to $1050 \mathrm{ml} / \mathrm{min}$. These operation ranges are based on the results of the first stage design of experiments. Their operation ranges are much narrower and close to the best operation conditions in the first stage design of experiments. The second stage design of experiments is to find which factor is the most significant among all factors. The detailed results of this design of experiments are shown in Table A-2.

From the results presented in the Table A-2, the statistical analysis results of this set design of experiments can be derived. The ANOVA table and the Effect Tests table are given in Table 4-15 and Table 4-16 respectively. 
Table 4-15 Analysis of Variance table for the second stage of design of experiment.

\begin{tabular}{|c|c|c|c|c|}
\hline \multicolumn{5}{|c|}{ Combustible material recovery } \\
\hline Source & DF & Sum of Squares & Mean Square & F Ratio \\
\hline Model & 3 & 1481 & 493.6 & 3.5 \\
\hline Error & 5 & 706 & 141.2 & Prob $>F$ \\
\hline C. Total & 8 & 2187 & & 0.106 \\
\hline \multicolumn{5}{|c|}{ Ash Content } \\
\hline Source & $\mathrm{DF}$ & Sum of Squares & Mean Square & F Ratio \\
\hline Model & 3 & 5.35 & 1.78 & 1.22 \\
\hline Error & 5 & 7.29 & 1.46 & Prob $>F$ \\
\hline C. Total & 8 & 12.64 & & 0.39 \\
\hline
\end{tabular}

Table 4-16 Effect Tests table of the second stage of design of experiment.

\begin{tabular}{|c|c|c|c|c|c|}
\hline Combustible Material Recovery & Nparm & DF & Sum of Squares & F Ratio & Prob>F \\
\hline Source & 1 & 1 & 1235.5 & 8.75 & 0.0316 \\
\hline Feed Solid Concentration & 1 & 1 & 96.6 & 0.68 & 0.4457 \\
\hline Collector Dosage & 1 & 1 & 148.6 & 1.05 & 0.352 \\
\hline Feed Rate & 1 & DF & Sum of Squares & F Ratio & Prob>F \\
\hline Ash Content & Nparm & D & 0.67 & 0.47 & 0.53 \\
\hline Source & 1 & 1 & 3.97 & 2.78 & 0.16 \\
\hline Feed Solid Concentration & 1 & 1 & 0.705 & 0.484 & 0.518 \\
\hline Collector Dosage & 1 & 1 & & &
\end{tabular}

From Table 15 and 16, if only these three operating parameters are used, the product ash of clean coal cannot be predicted precisely. This may be the effect of other factors also needed to be considered to achieve a better prediction. However, when these three factors themselves are compared, it is also meaningful to choose the most significant one. The effect tests results show that the collector dosage has the smallest $\mathrm{P}$ value of 0.16 , which is much smaller than the $\mathrm{P}$ values of the other two factors. This means the change in the range of collector dosage will cause the greatest 
variance in the clean coal ash content. Thus the collector dosage should be most strictly controlled in order to obtain the highest clean coal quality. The response surface plots and contour plots to present the trend of combustible material recovery and clean coal ash content with the change of these three operating parameters of including feed solid concentration-collector dosage, feed rate-feed solid concentration, and feed rate-collector dosage are given in Figure 4-10, Figure 4-11 and Figure 4-12, respectively.

From the variation tendency of clean coal ash combined with these three factors, in order to obtain the clean coal with better quality, the feed solid concentration should be kept in lower level, while the feed rate stays in the middle level of its operation range. As to the collector dosage, this series of experiments indicates using more collectors because it is accompanied with lower product ash. However, from the first set of column flotation experiments, if the collector dosage reaches $1 \mathrm{~kg} / \mathrm{mt}$, it does not lead to the lowest clean coal ash. It means the $1 \mathrm{~kg} / \mathrm{mt}$ of collector concentration is overdose. The average of clean coal ash at collector dosage of 0.75 $\mathrm{kg} / \mathrm{mt}$ is only $0.13 \%$ lower than the average clean coal ash when the collector concentration is $0.6 \mathrm{~kg} / \mathrm{mt}$. This value is much lower than the difference of average clean coal ash when the collector dosage is between 0.6 and $0.45 \mathrm{~kg} / \mathrm{mt}$. Thus it can be inferred that the collector dosage at $0.75 \mathrm{~kg} / \mathrm{mt}$ may have reached its effect limit in improving the clean coal ash. Thus in order to obtain the optimum operation conditions for this difficult-to-float subbituminous coal in the column flotation, the most significant factor, collector dosage, is chosen as the variable in the third stage of design experiments. The other two factors are fixed at the favorable level that can produce best quality of clean coal. 
(a)
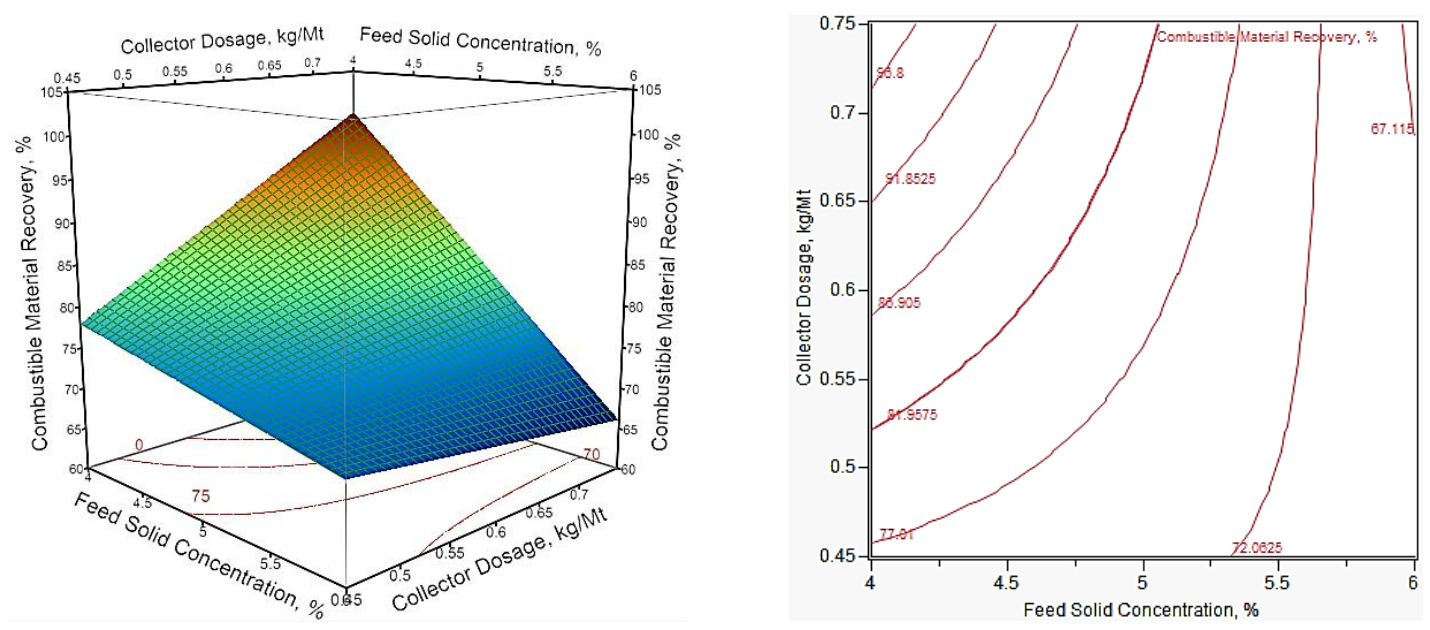

(b)
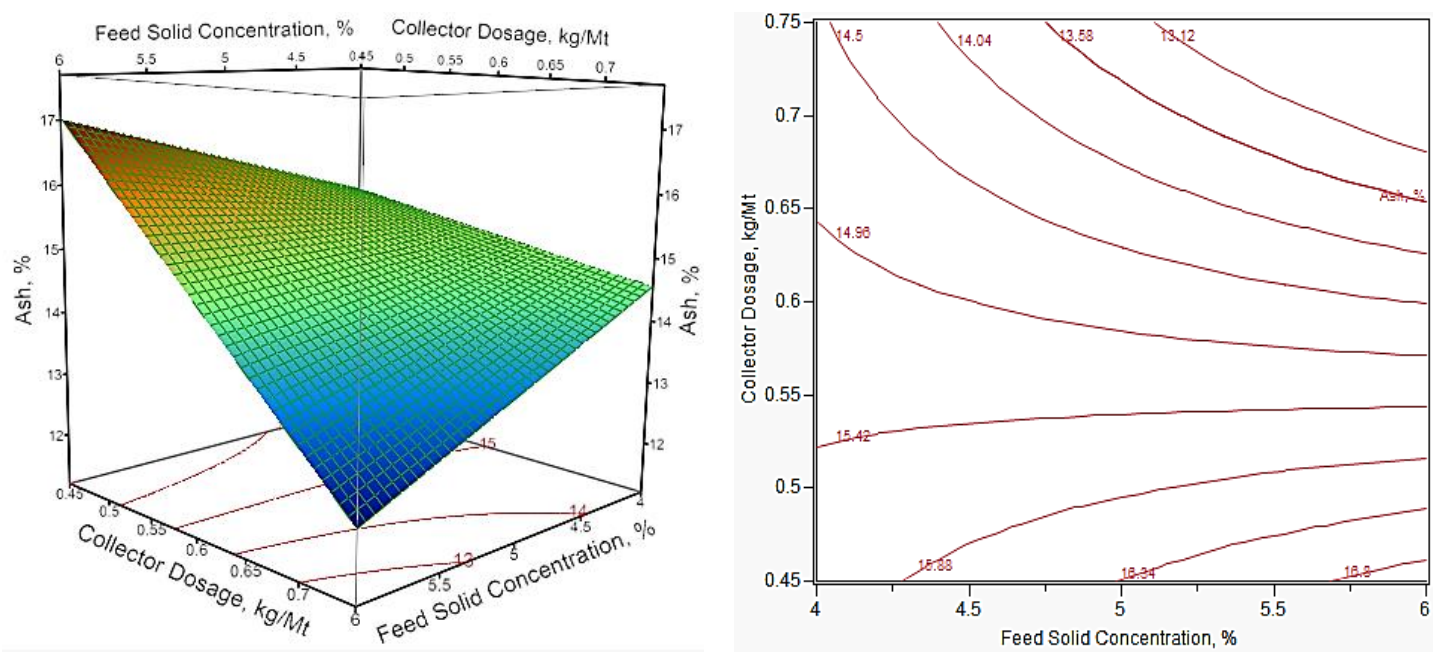

Figure 4-10 Effect of feed solid concentration and collector dosage on (a) combustible material recovery and (b) clean coal ash content. 
(a)
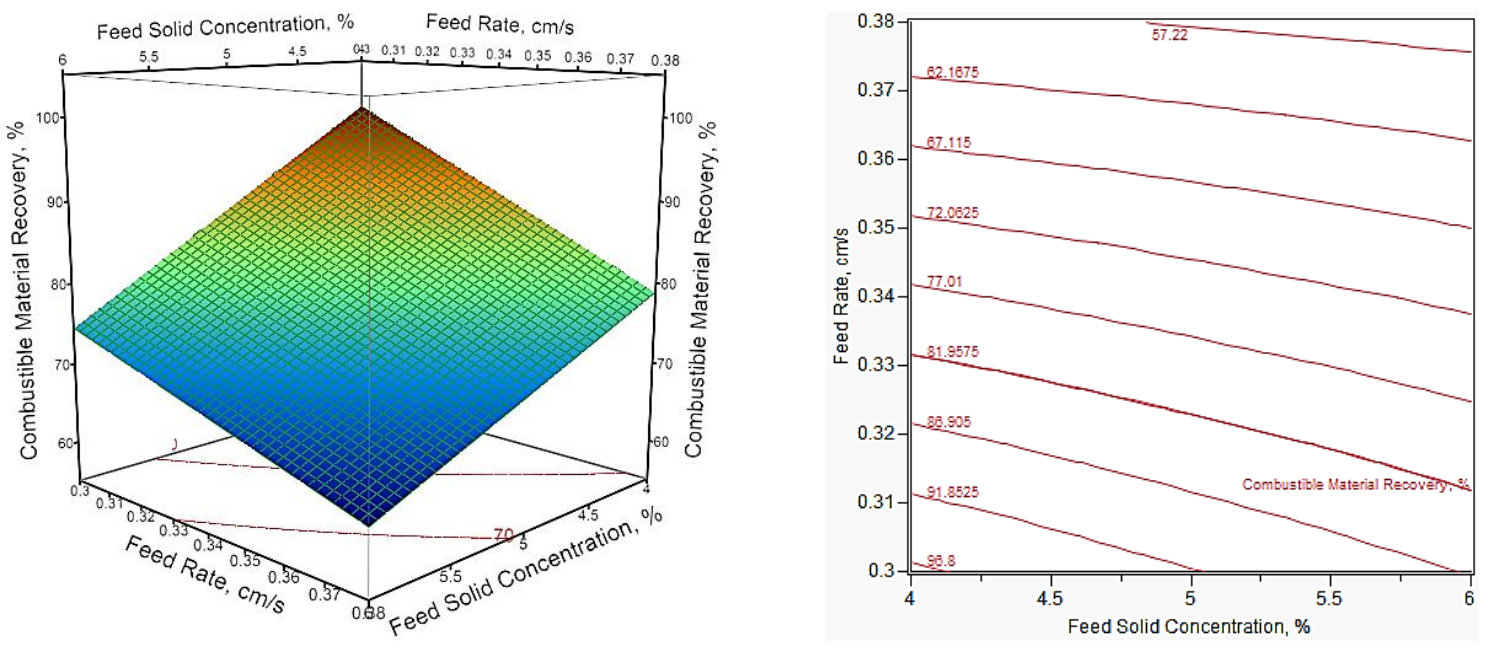

(b)
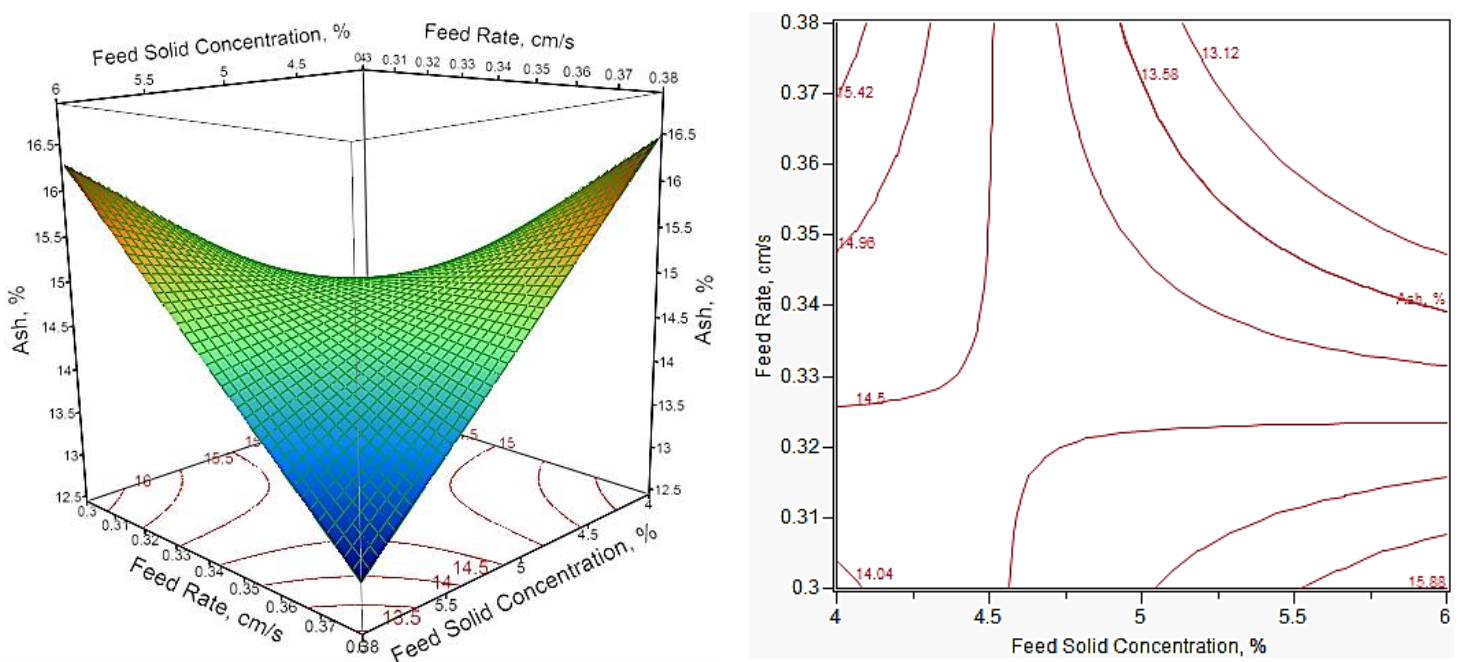

Figure 4-11 Effect of feed rate and feed solid concentration on the clean coal product ash for subbituminous coal. 
(a)
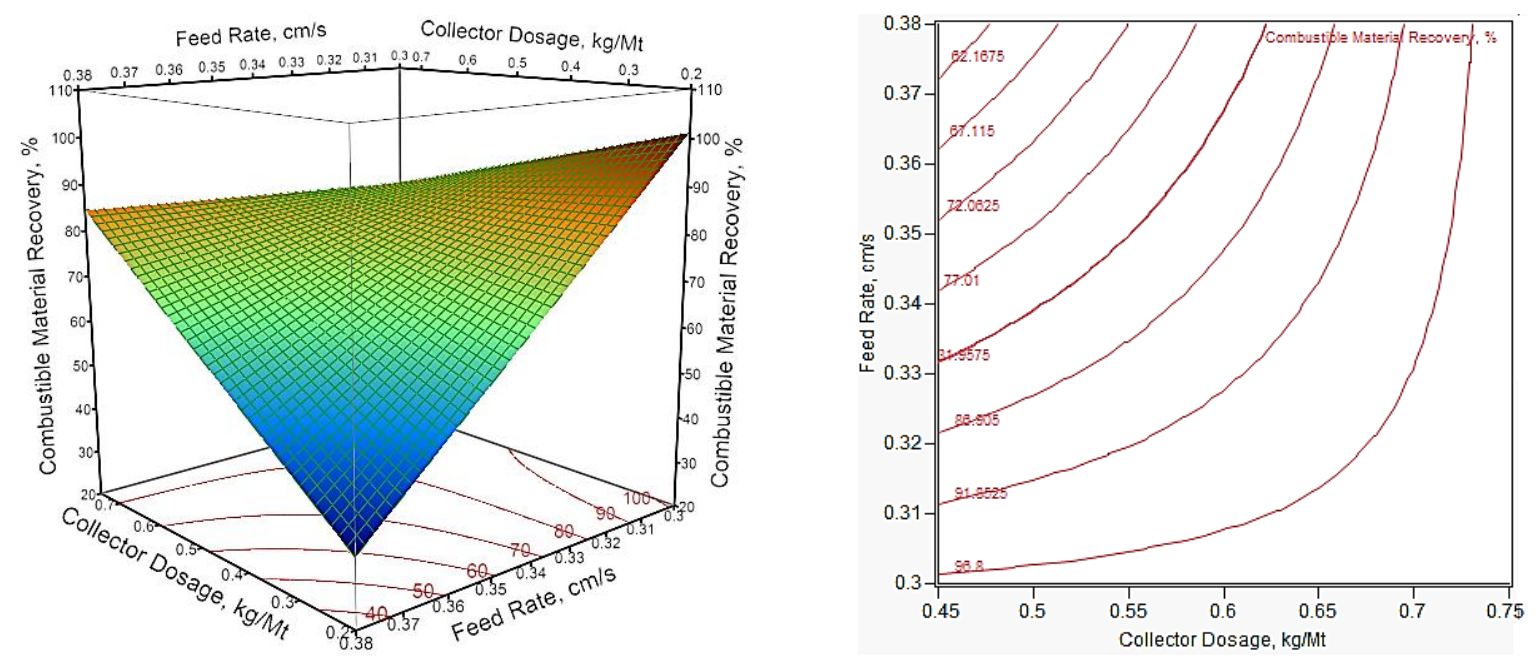

(b)
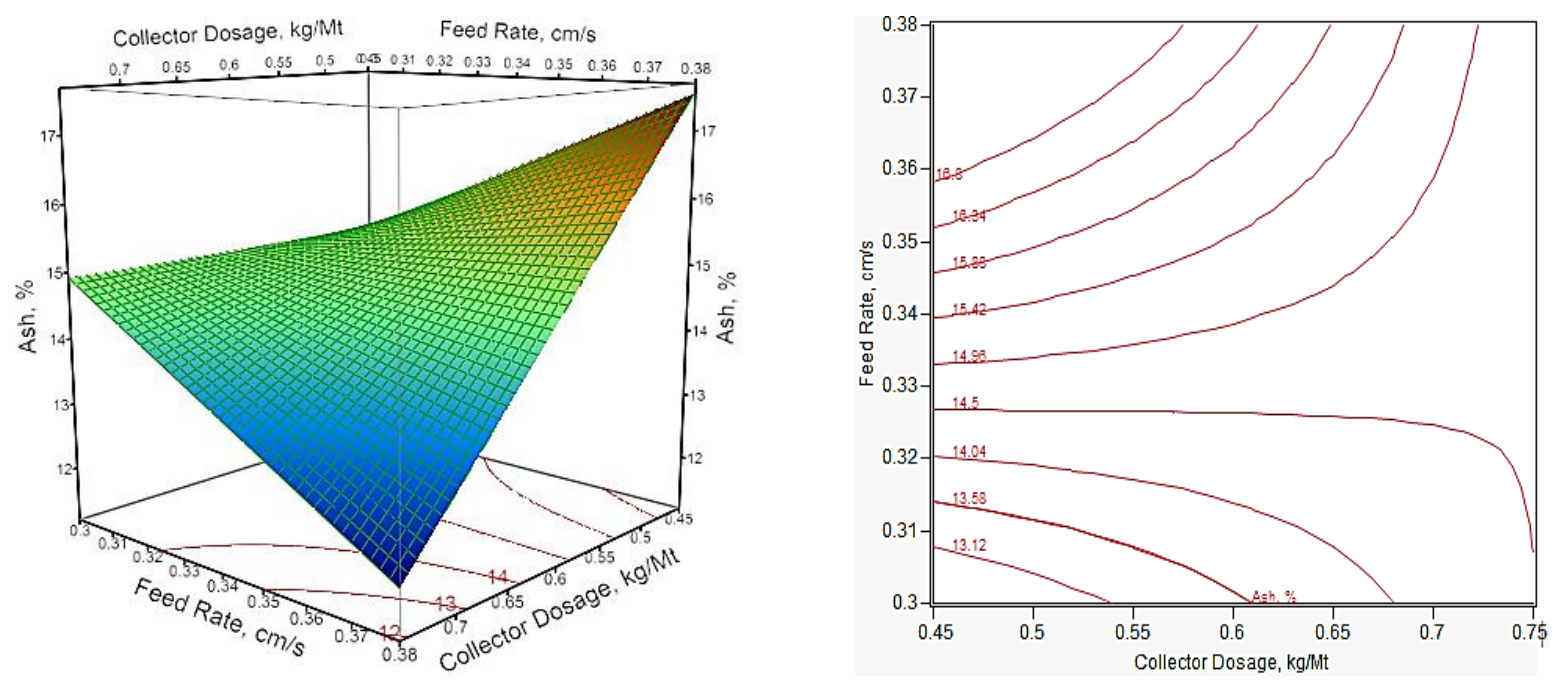

Figure 4-12 Effect of collector dosage and feed rate on the clean coal product ash

for subbituminous coal. 
As the method stated in previous section about the third stage design of experiment, collector dosage is considered as the variable and the remaining five factors keep constant to find the optimal operation conditions. In this series of experiments, the operation conditions include $4 \%$ solid concentration, $0.384 \mathrm{~cm} / \mathrm{s}$ feed rate, $0.75 \mathrm{~cm} / \mathrm{s}$ air flow rate, and $0.092 \mathrm{~cm} / \mathrm{s}$ wash water rate, while collector dosage is varied from $0.75 \mathrm{~kg} / \mathrm{mt}$, by increment of $0.05 \mathrm{~kg} / \mathrm{mt}$ to $0.9 \mathrm{~kg} / \mathrm{mt}$. The third stage design of experiments is given in Table 4-17.

This set of design of experiments has narrowed the variable, collector dosage, to the smallest operation range around the best level in the second stage design of experiment that can obtain the highest quality of clean coal. If the best collector dosage for the column flotation is found, the last one and the most significant one factor that affects the clean coal quality can be decided. The flotation result of the third stage design of experiment is shown in Table A-3. Figure 4-13 shows the correlation between the collector dosage and combustible material recovery and clean coal ash content. 
Table 4-17 Third stage design of experiments.

\begin{tabular}{|c|c|c|c|c|c|c|}
\hline $\begin{array}{c}\text { Exp. } \\
\text { No. }\end{array}$ & $\begin{array}{c}\text { Collector } \\
\text { Dosage, } \\
\mathrm{kg} / \mathrm{mt}\end{array}$ & $\begin{array}{c}\text { Feed } \\
\text { Rate, } \\
\mathrm{cm} / \mathrm{s}\end{array}$ & $\begin{array}{c}\text { Frother } \\
\text { Dosage, } \\
\mathrm{kg} / \mathrm{mt}\end{array}$ & $\begin{array}{c}\text { Air Flow } \\
\text { Rate, } \\
\mathrm{cm} / \mathrm{s}\end{array}$ & $\begin{array}{c}\text { Wash } \\
\text { Water, } \\
\mathrm{cm} / \mathrm{s}\end{array}$ & $\begin{array}{c}\text { Feed Solid } \\
\text { Concentration, \% }\end{array}$ \\
\hline 1 & 0.75 & 0.35 & 0.12 & 0.75 & 0.092 & 4 \\
\hline 2 & 0.8 & 0.35 & 0.12 & 0.75 & 0.092 & 4 \\
\hline 3 & 0.85 & 0.35 & 0.12 & 0.75 & 0.092 & 4 \\
\hline 4 & 0.9 & 0.35 & 0.12 & 0.75 & 0.092 & 4 \\
\hline
\end{tabular}

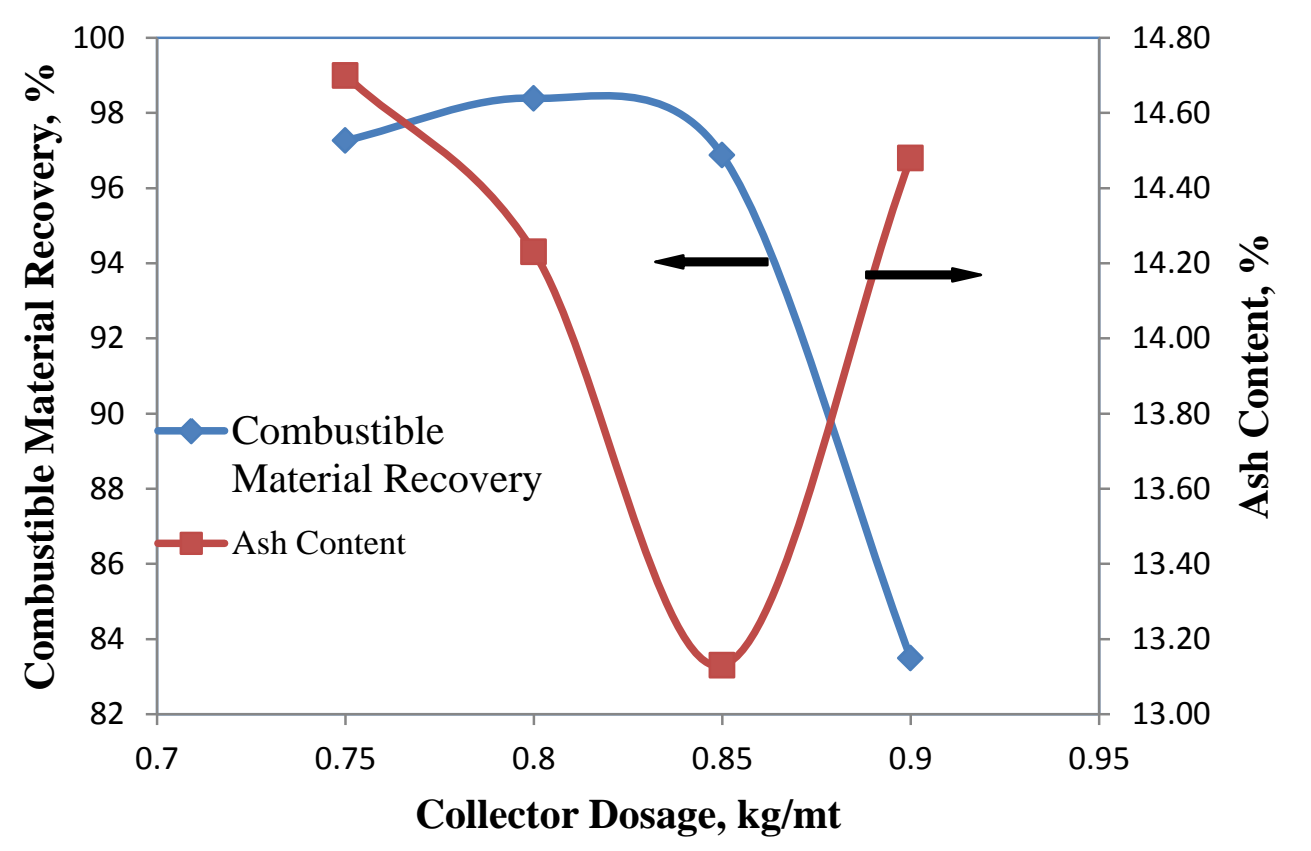

Figure 4-13 Correlation between the collector dosage and combustible material recovery and clean coal ash for subbituminous coal flotation.

When the collector dosage increased from 0.75 to $0.85 \mathrm{~kg} / \mathrm{mt}$, the clean coal ash content first reduced and then increased. This result shows the effect of collector on the clean coal quality has reached its best amount. The best clean coal quality is achieved at the collector dosage of $0.85 \mathrm{~kg} / \mathrm{mt}$. When the collector concentration continues enhance to $0.9 \mathrm{~kg} / \mathrm{mt}$, the clean coal ash content increases from $13.13 \%$ to 
14.48\%. This result is consistent with the previous studies that the overuse of collector will reduce the selectivity of coal flotation. The excess amount of collector can absorb on the mineral particles that become hydrophobic to float instead of sink. For these reasons, the collector dosage should be controlled more strictly to get the best quality of clean coal such as ash content.

As to the combustible material recovery, when the collector dosage increased from $0.75 \mathrm{~kg} / \mathrm{mt}$ to $0.85 \mathrm{~kg} / \mathrm{mt}$, the combustible material reduces from $97.27 \%$ to 96.87\%. This result proves that most of the coal particles in the feed coal can be recovered. Though the combustible material is reduced with the increased collector dosage, this result is acceptable accompanied with the clean coal quality.

When the flotation performances of these three stages design of experiment are compared with the flotation results of the release analysis of feed coal, their relations expressed as combustible material recovery as a function of clean coal ash content are given in Figure 4-14. From this figure, most of the data points of the design of experiments fall into thearea below the release analysis line. Compared to the data points of the first stage, data points of the second stage are in a more compact area in the left part area of first stage. The data points of the third stage are mostly in a small area above the release analysis line, this means the column flotation experiments achieved the result that are better than the ideal results of stirred tank cell flotation on subbituminous coal. This proves that the pico and nano bubble used in the column flotation is more effective in the flotation of the difficult-to-float coal. 


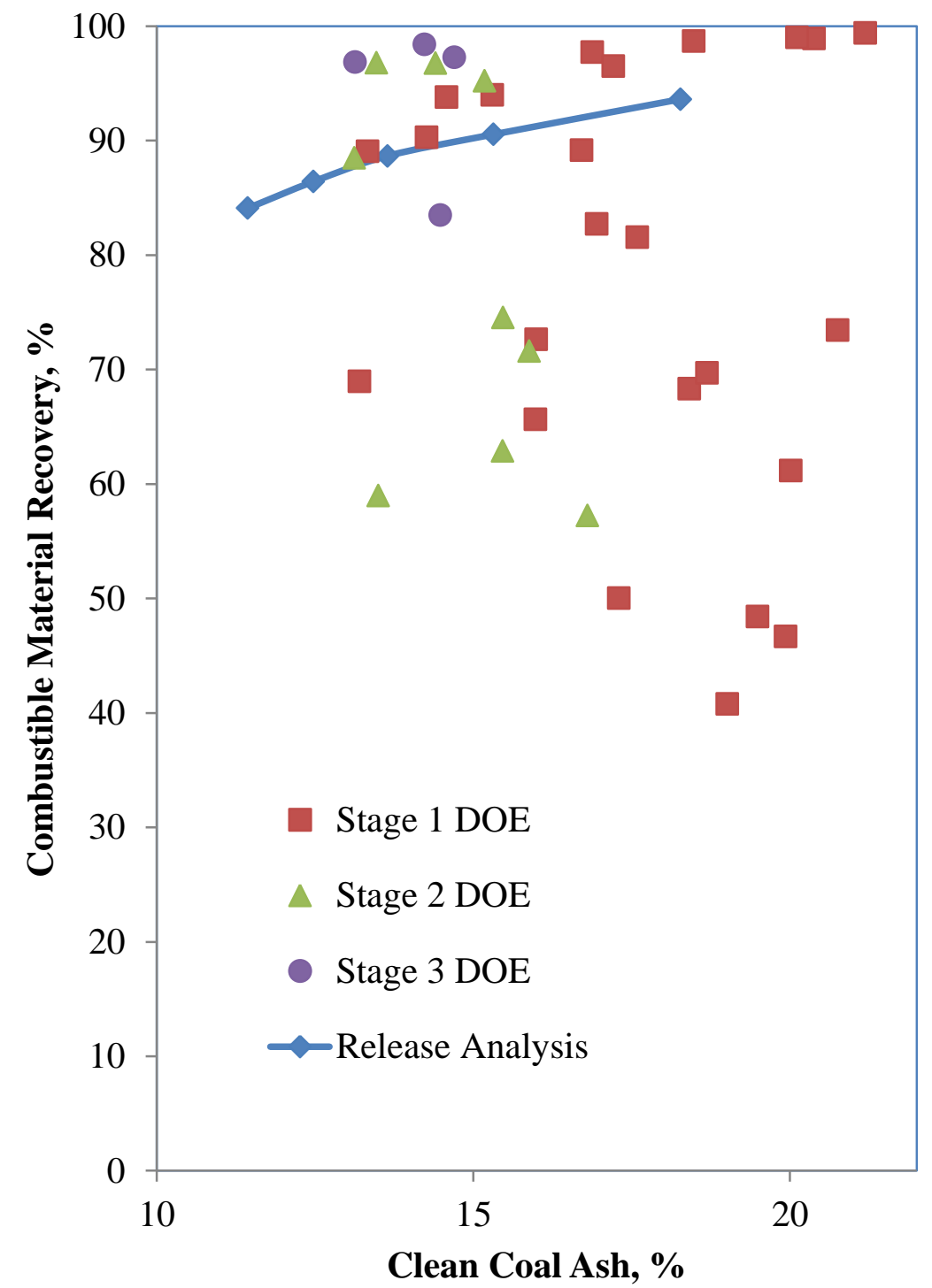

Figure 4-14 Flotation results of release experiments and the three stage of design of experiments.

Some of the coal particles might be misplaced to the tailings stream. In the other aspect, ultrafine mineral particles particularly clay mineral particles can be floated to the froth layer by the effect of entrapment or even be brought to the froth layer by the upward water stream. In flotation column, wash water system is installed for washing off the entrained mineral particles to minimize the clean coal ash content.

Compared with the semi-batch cell flotation results, the separation efficiency of 
column flotation is much higher than the stirred tank cell flotation both in combustible material recover and clean coal quality. In the stirred tank cell flotation, the clean coal obtained is always with more than $15 \%$ of ash content when MIBC or TTT frother was used as frother. That ash content is higher than the ash content of clean coal produced by column flotation. It shows the column flotation is more favorable in floating low rank coal. The combustible material recovery achieved from column flotation is generally higher than it is obtained from the stirred tank cell flotation. Therefore considering both clean coal recovery and clean coal quality, the column flotation using pico and nano bubbles is superior to the semi-batch flotation.

Additionally, the chemical reagent dosages used in the column flotation is much lower than the semi-batch cell flotation. The TTT frother dosage for the best column flotation condition is $0.12 \mathrm{~kg} / \mathrm{mt}$, this is half amount of frother dosage used in the semi-batch cell flotation, at highest combustible material recovery and lowest clean coal ash content. The collector dosage used for the column flotation is $0.85 \mathrm{~kg} / \mathrm{mt}$. It is also less than a half of the amount of collector dosage used during semi-batch cell flotation with the best flotation performance at $1.5 \mathrm{~kg} / \mathrm{mt}$. It clearly shows that the column flotation can use the flotation reagents much more efficiently and economically.

In comparing the column flotation results with the release analysis test results, which is regarded as the ideal separation of stirred tank cell flotation, the column flotation result can produce clean coal higher combustible material recovery with clean coal ash content around $13 \%$. The recovery-grade curve of the release analysis reflects that if ash content of clean coal lower than $13.6 \%$ is required, the combustible material recovery will not exceed $89 \%$. However, the column flotation result shows 
the best clean coal ash of $13.13 \%$ with the combustible material recovery of $96.87 \%$. In this case, the column flotation performance has broken through the so called "ideal separation". This result must be caused by the effect of pico and nano bubbles used in the column flotation. One significant effect of the pico and nano bubble is its huge quantity existing in the column cell. The size of the air bubbles generated by the venturi cavitation tube is much smaller than the size of air bubble generated by the conventional sparger (Fan et al., 2010), including microbubble generator-static mixer. Under the same amount of air injection rate, the smaller size of single air bubbles means larger quantity of air bubble produced. When the venturi cavitation tube bubble generation system is applied, the pico and nano bubbles can occupy almost every corner of the flotation column cell and maintain its tiny size for a long time. This means the probability of collision and attachment between the coal particles and the air bubbles becomes much higher. When dealing with difficult-to-float coal, the advantages of pico and nano bubbles becomes more obviously. Because the subbituminous coal has naturally oxidized surface, it is hard for the attachment of the oxidized coal particle on the air bubbles (Jena et al., 2008). The using of the pico and nano bubbles in the column flotation increases the probability of collision between coal particles and the air bubbles, and also reduces the probability of their detachment. The pico and nano bubbles can be adsorbed on the hydrophobic part of the coal surface readily because of the attraction between hydrophobic coal and hydrophobic bubble surfaces, and small size of air bubbles. 


\subsection{Effect of Ultrafine Mineral Particles on Flotation}

As for the best clean coal obtained from the third stage design of experiment, the ash content is $13.31 \%$. From the wet sieving result, it shows the ash content of the ultrafine particles (minus $45 \mu \mathrm{m}$ ) of the clean coal product is $18.32 \%$. The high ash content of the ultrafine particles shows it contains many mineral particles in it. In addition, the clay particles present floatability and have very small size, which is a main component of the ultrafine particles of coal sample. In this case, if we cut off the ultrafine particles under $45 \mu \mathrm{m}$ from the clean coal product is removed, its ash content can reach $10.4 \%$ and total combustible material recovery reduces to $65.3 \%$. This shows the clean coal quality can be improved further after removable of the ultrafine particles from clean coal product.

In this experiment, the ultrafine particles (minus $45 \mu \mathrm{m}$ ) were deslimed from the feed coal before column flotation. The feed coal ash content reduced to $20.6 \%$. This can test whether the flotation performance result can be improved after desliming the feed coal. The operation parameters and experiment results are shown in Table 4-18.

The column flotation results show the clean coal ash reduces to $9.1 \%$ with the combustible material recovery of $81.15 \%$, when desliming the feed coal before column flotation. The negative effect of clay particles is reduced on the flotation of subbituminous coal. Therefore, it provides another way to improve the clean coal quality, while the feed coal has high content of ultrafines with high content of clay minerals. 
Table 4-18 Column Flotation Test on Feed Coal after Desliming minus $45 \mu \mathrm{m}$ particles.

\begin{tabular}{|c|c|c|c|c|c|}
\hline $\begin{array}{c}\text { Kerosene, } \\
\mathrm{kg} / \mathrm{mt}\end{array}$ & $\begin{array}{c}\text { TTT Frother, } \\
\mathrm{kg} / \mathrm{mt}\end{array}$ & $\begin{array}{c}\text { Feed Solid } \\
\text { Concentration, } \%\end{array}$ & $\begin{array}{c}\text { Clean Coal } \\
\text { Ash, } \%\end{array}$ & $\begin{array}{c}\text { Tailings } \\
\text { Ash, } \%\end{array}$ & $\begin{array}{c}\text { CMR } \\
, \%\end{array}$ \\
\hline 0.85 & 0.12 & $4 \%$ & 9.1 & 48.6 & 81.15 \\
\hline $\begin{array}{c}\text { Air Flow } \\
\text { Rate, } \mathrm{cm} / \mathrm{s}\end{array}$ & $\begin{array}{c}\text { Feed Rate, } \\
\mathrm{cm} / \mathrm{s}\end{array}$ & $\begin{array}{c}\text { Wash Water, } \\
\mathrm{cm} / \mathrm{s}\end{array}$ & $\begin{array}{c}\text { Clean Coal } \\
\text { Yield, } \%\end{array}$ & $\begin{array}{c}\text { Tailings } \\
\text { Yield, } \%\end{array}$ & \\
\hline 0.75 & 0.35 & 0.092 & 70.89 & 29.11 & \\
\hline
\end{tabular}




\section{CHAPTER 5 \\ CONCLUSIONS}

From the series of experiments results, based on the column flotation of hard-to-float coal, using pico and nano bubbles, the following conclusions can be drawn.

1. In the semi-batch cell flotation, three chemical reagents, kerosene-MIBC, and kerosene-trimethyl pentanediol derivatives frother (TTT frother), were used separately, to evaluate initial reagents requirements and the effects on flotation of subbituminous coal. The use of combination of kerosene and TTT frother gives higher combustible material recovery and lower clean coal ash content than using the combination of kerosene and MIBC.

2. Flotation rate in a 2 liter stirred tank cell flotation experiments show the subbituminous coal is difficult to float compared with the Pittsburgh \#8 coal (high volatile bituminous coal). This is because of the naturally oxidized property of subbituminous coal. The TTT frother can improve the combustible material recovery of subbituminous coal in comparing with the conventional frother of MIBC.

3. The release analysis experiment and stirred tank cell flotation shows the floatability of low rank of coal, subbituminous coal. The best clean coal obtained from the release analysis experiment has combustible material recovery of $84.1 \%$ and ash content of $11.44 \%$. This result proves the use of kerosene and TTT frother can achieve good selective floatation of the lower rank coal.

4. From the first stage statistical design of experiment, the feed solid concentration, 
collector dosage and feed rate are the three comparably significant factors that affect the clean coal ash content. The purpose is to achieve the highest quality of clean coal in accompany with combustible material recovery as high as possible. The ranges of feed solid concentration, frother dosage, and feed rate have been narrowed as the variable factors in the second stage design of experiment to pursue the lower clean coal ash content. The other three factors are set at the level that can obtain highest combustible material recovery.

5. From the second stage statistical design of experiments, the collector dosage is proved to be the most significant factor that influences the clean coal quality. Thus the collector dosage should be controlled most strictly to achieve the highest quality of clean coal product. The insufficient use of collector does not lead to the best selective flotation of the feed coal. While the overdose of the collector can cause the mineral surface become hydrophobic.

6. The third stage statistical design of experiment shows the best collector dosage required in the column flotation is $0.85 \mathrm{~kg} / \mathrm{mt}$. Therefore in these series of design of experiment, the optimum operation conditions for the difficult-to-float subbituminous coal are determined are, $0.85 \mathrm{~kg} / \mathrm{mt}$ kerosene, $0.12 \mathrm{~kg} / \mathrm{mt}$ TTT frother, $4 \%$ feed solid concentration, $0.75 \mathrm{~cm} / \mathrm{s}$ air flow rate, $0.35 \mathrm{~cm} / \mathrm{s}$ feed rate, and $0.092 \mathrm{~kg} / \mathrm{mt}$ wash water rate. In these conditions, the clean coal product can achieve the combustible material recovery of $96.87 \%$ and ash content of $13.13 \%$. These results show a very good selective flotation of subbituminous coal.

7. The high separation performance of subbituminous coal using column flotation not only attributed to the use of TTT frother, but also the pico and nano bubbles. The application of the pico and nano bubbles greatly enhances the probabilities 
of collision and attachment, and lowers the probability of detachment between the air bubbles and the coal particles, that enhances its recovery.

8. When the ultrafine coal smaller than $45 \mu \mathrm{m}$ is deslimed from clean coal, the ash content reduces to $10.4 \%$ and the total combustible material recovery lowered to $65.3 \%$. When the ultrafine coal is deslimed from the feed coal before column flotation, the clean coal product can have combustible material recovery of $81.15 \%$ and ash content of $9.1 \%$. 


\section{RECOMMENDATIONS}

According to the results conducted, further study in the following parts is recommended:

1. The TTT frother has been proved to be a good frother for the flotation of lower rank coal. Some other types of frothers that have been produced for the oxidized coal flotation should be tested. In addition, the compositions of frother should also be studied for their co-effect on the flotation of difficult-to-float coal.

2. The detailed study on the effect of the blend of TTT components on the surface tension reduction, or the interaction between the TTT frother and the coal particles should be studied. Since the increased dosage of TTT frother can not only increase the combustible material recovery, but also reduce the clean coal ash content. This enhanced selectivity might come from the frother.

3. The column flotation on the coarse particles of the subbituminous coal should be studied further to increase the feed coal size range of the flotation. The method that may achieve this purpose includes using a better collector or frother for the flotation difficult-to-float coal. Use some promoter or activator to instigate the adsorption of collectors on the coal particles that improves the hydrophobicity of the coal surfaces thus obtained recovery. 


\section{REFERENCES}

Ahmed, H. A. M., and Drzymala, J., 2012, "Upgrading difficult-to-float coal using microemulsion”, Minerals \& Metallurgical Processing, Vol. 29, pp. 88-96

Atesok, G., Celik, and M. S., 2000, "A new flotation scheme for a difficult-to-float coal using pitch additive in drying grinding", Fuel, Vol. 79, pp. $1509-1513$

Atesok, G., Boylu, F., and Celik, M. S., 2001, "Carrier flotation for desulfurization and deashing of difficulty-to-float coals", Minerals Engineering, Vol. 14, pp. 661-670

Atesok, G., and Celik, M. S., 2000, "A new flotation scheme for a difficult-to-float coal using pitch additive in dry grinding", Fuel, Vol. 79, pp. $1509-1513$

Arun, B. M., Ron, Z., Prosun, B., Kenneth, S. S., and Ryunosuk, K., 2008, "Mercury flow via coal and coal utilization by-products: A global perspective, Resources", Conservation and Recycling, Vol. 52, pp. 571-591

Banford, A. W., and Aktas, Z., 2004, "The effect of reagent addition strategy on the performance of coal flotation", Minerals Engineering, Vol. 17, pp. 745-760

Bolat, E., Saglam, S., and Piskin, S., 1998, "The effect of oxidation on the flotation properties of a Turkish bituminous coal", Fuel Processing Technology, Vol. 55, pp. 101-105

Chen, W. S., Liu, J. T., Li, X. B., Cao, Y. J., and Wang, Y. T., 2008, "Analysis of factors influencing fluorite flotation by cyclonic static micro-bubble flotation column", Metal Mine, Vol. 5, pp. 101-102

Cowburn, J., Harbort, G., Manlapig, E., and Pokrajcic, Z., 2006, "Improving the Revovery of Coarse Coal Particles in a Jameson Cell”, Minerals Engineering, Vol. 19, pp. 609-618

Dey, S., 2012, "Enhancement in hydrophobicity of low rank coal by surfactantsA critical overview", Fuel Processing Technology, Vol. 94, pp. 151-158

Dube, R. M., 2012, "Collectors for Enabling Flotation of Oxidized Coal", Master's Thesis, University of Kentucky, Lexington, KY

Fan, M. M., Tao, D., Rick, H., and Luo, Z. F., 2010, "Nanobubble generation and its application in froth flotation (partI): nanobubble generation and its effects on properties of microbubble and millimeter scale bubble solutions", Mining Science and Technology, Vol. 20, pp. 1-19

Fan, M. M., Tao, D., Rick, H., and Luo, Z. F., 2010, "Nanobubble generation and 
its application in froth flotation (partII): fundamental study and theoretical analysis", Mining Science and Technology, Vol. 20, pp: 159-177

Fan, M. M., Tao, D., Rick, H., and Luo, Z. F., 2010, "Nanobubble generation and its application in froth flotation (part III): specially designed laboratory scale column flotation of phosphate", Mining Science and Technology, Vol. 20, pp. 317-338

Fan, M. M., Tao, D., Rick, H., and Luo, Z. F., 2010, "Nanobubble generation and its application in froth flotation (part IV): mechanical cells and specially designed column flotation of coal", Mining Science and Technology, Vol. 20, pp: 641-671

Finch, J. A., 1995, "Column flotation: A selected review-part IV: Novel flotation devices”, Minerals Engineering, Vol. 8, pp. 587-602

Fuerstenau, D. W. et al., 1990, "Coal Surface Control for Advanced Fine Coal Flotation”, Quarterly Report, Utah University, Salt Lake City, UT

Gupta, A. K., Banerjee, P. K., Mishra, A., Satish, P., and Pradip, 2007, "Effect of alcohol and polyglycol ether frothers on foam stability, bubble size and coal flotation", International Journal of Mineral Process, Vol. 82, pp. 126-137

Hart, G., Morgan, S., Bramall, N., and Nicol, S. K., 2002, "Enhanced coal flotation using picobubbles", Final Report, Australian Coal Association Research Program

Jena, M. S., Biswal, S. K., and Rudramuniyappa, M. V., 2008, "Study on flotation characteristics of oxidized Indian high ash subbituminous coal", International Journal of Mineral Processing, Vol. 87, pp. 42-50

Jia, R., Guy, H. H., and Douglas, W. G., 2000, "An improved class of universal collectors for the flotation of oxidized and/or low-rank coal", International Journal of Miner. Process, Vol. 58, pp. 99-118

Kappele, W. D., 1998, "Using I-Optimal Designs for Narrower Confidence Limits", IASI conference

Khoshdast, H., and Sam, A., 2011, "Flotation Frothers: Review of Their Classifications, Properties and Preparation", The Open Mineral Processing Journal, Vol. 4, pp. 25-44

Koh P. T. L., and Schwarz, M. P., 2007, "CFD model of a self-aerating flotation cell”, International Journal of Mineral Processing, Vol. 85, pp. 16-24

Lahey, A. E., Clarkson, C. J., and Brake, I., 1998, "Microcel ${ }^{\mathrm{TM}}$ Flotation Column Modelling”, Coal Preparation, Vol. 19, pp. 83-113

Li, B., Tao, D., Ou, Z., and Liu, J., 2003, "Cyclo-microbubble column flotation of fine coal”, Separation Science and Technology, Vol. 38, pp. 1125-1140 
Liu, C. C., Xie, G. Y., and Wu, L., 2006, "The application of FCMC type cyclonic microbubble flotation column in small or middle coal preparation", Coal Engineering, Vol. 3, pp. 54-56

Liu, J. T., 2006, "Preparation of ultra clean coal using cyclonic-static microbubble flotation column”, China Association for Science and Technology, Vol. 2, pp. 60-67

Lynch, A. J., Watt, J. S., Finch J. A., and Harbort, G. E., 2007, "Hystory of Flotation Technology", Froth Flotation: A Cenruty of Innovation, pp. 65-132

Marek P., and Janusz, S. L., 2003, "Coal Reverse Flotation. Part I. Adsorption of Dodecyltrimethyl Ammonium Bromide and Humic Acid onto Coal and Silica", Coal Preparation, Vol. 23, pp. 91-112

Marek P., and Janusz, S. L., 2003, "Coal Reverse Flotation. Part 2. Batch Flotation Tests", Coal Preparation, Vol. 23, pp 113-127

Mitchell, G., Polat, H, Davis, A, and Chander, S., 1995, "Surface properties of photo-oxidized bituminous coals", Technical Progress Report, July-September, Pennsylvania State University, PA

Murat, E., Cigdem, C., and Zeki, A., 2003, "The effect of reagents and reagent mixtures on froth flotation of coal fines", Int, J. Miner. Process, Vol. 71, pp. 131-145

Naik, P. K., Reddy, S. R., and Misra, V. N., 2005, "Interpretation of interaction effects and optimization of reagent dosages for fine coal flotation", International Journal of miner. Process, Vol. 75, pp. 83-90

Polat, M., and Chander, S., 2000, "First-order Flotation Kinetics Models and Methods for Estimation of the True Distribution of Flotation Rate Constants", International Journal of Mineral Processing, Vol 58, pp. 145-166

Polat, M., Polat, H., and Chander, S., 2003, "Physical and chemical interactions in coal flotation", International Journal of Mineral Processing, Vol. 72, pp. 199-213

Randolph, J. M., 1997, "Characterizing flotation response: a theoretical and experimental comparison of techniques”, Master Thesis, Virginia Polytechnic Institute and State University, VA

Safak, G. O., and Halit, Z. K., 2006, "Investigation of mechanism of ultrasound on coal flotation", Int. J. Miner. Process. Vol. 81, pp. 201-203

Safak, and G. O., 2012, "Effects of simultaneous ultrasonic treatment on flotation of hard coal slimes", Fuel, Vol. 93, pp. 576-580

Sarikaya, M., and Ozbayoglu, G., 1995, "Flotation characteristics of oxidized 
coal", Minerals Engineering, Vol. 14, pp. 231-234

Sis, H., Ozbayoglu, G., and Sarikaya, M., 2003, "Comparison of Non-ionic and Ionic Collectors in the Flotation of Coal Fines", Minerals Engineering, Vol. 16, pp. 399-401

Somasundaran, P., Roberts, C. E., and Ramesh, R., 1991, "Effects of oxidizing methods on the flotation of coal", Minerals Engineering, Vol. 4, pp. 43-48

Tao, D, 2005, "Role of Bubble Size in Flotation of Coarse and fine Particles-A Review”, Separation Science and Technology, Vol. 39, pp. 741-760

Tao, D., Li, B., Johnson, B., and Parekh, B. K., 2002, "A flotation study of refuse pond coal slurry”, Fuel Processing Technology, Vol. 76, pp. 201-210

Tao, X. X., Cao, Y. J., Liu, J., Shi, K. Y., Liu, J. Y., and Fan, M. M, 2009, “Studies on characteristics and flotation of a hard-to-float high-ash fine coal", Procedia Earth and Planetary Science, Vol. 1, pp. 799-806

Tao, Y. J., Liu, J. T., Yu, S., and Tao, D., 2007, "Picobubble enhanced fine coal flotation", Separation Science and Technology, Vol. 41, pp: 3597-3607

Vamvuka, D., and Agridiotis, V., 2001, "The effect of chemical reagents on lignite flotation”, Int. J. Miner. Process, Vol. 61, pp. 209-224

Wang, H., Dlugogorski, B. Z., and Kennedy, E. M., 2003, "Analysis of the mechanism of the low-temperature oxidation of coal", Combustion and Flame, Vol. 134, pp. 107-117

Wang, H., Dlugogorski, B. Z., and Kennedy, E. M., 1999, "Theoretical analysis of reaction regimes in low-temperature oxidation of coal”, Fuel, Vol. 8, pp. 1073-1081

Wang, H, Dlugogorski, B. Z., and Kennedy, E. M., 2003, "Coal oxidation at low temperatures: oxygen consumption, oxidation products, reaction mechanism and kinetic modeling”, Progress in Energy and Combustion Science, Vol. 29, pp. 487-513

Xia, W. C., Yang, J. G., and Zhu, B., 2012, "Flotation of oxidized coal dry-ground with collector", Powder Technology, Vol. 228, pp. 324-326

Xia, W. C., Yang, J. G., and L, C., 2013, "A short review of improvement in flotation of low rank/oxidized coals by pretreatments", Powder Technology, Vol. 237, pp. $1-8$

Xie, G. Y., Wu, L, Ou., Z. S., and Yu., H. S., 2009, "Research on fine coal classified flotation process and key technology", Procedia Earth and Planetary Science, Vol. 1, pp. 701-705

Xia, Y. K., and Li, J. G., 2007, "Fine coal circuitry considerations in treatment of 
soft coal with difficult washabilities", Fuel Processing Technology, Vol. 88, pp. 759-769

Xu, Z. H., Liu, J. J., Choung, J. W., and Zhou, Z. A., 2003, "Electrokinetic study of clay interactions with coal in flotation", International Journal of Mineral Processing, Vol. 68, pp. 183-196

Yang, T., Huo X. L., and Yu, H. S., 2008, "The Analysis of Factors Affecting Cyclonicmicro-bubble Column Flotation”, Clean Coal Technology, Vol. 14, pp. 12-14

Zhang, H. J., Liu, J. T., and Wang, Y. T., 2006, "Separating Principle and Parameter Controlling for Cyclonic-Static Microbubble Flotation Column", China Mining Magazine, Vol. 15, pp. 70-72

Zhou, X. H., Liu, J. T., Wang, Y. T., Zhang, M. Q., and Zhang, M., 2011, "Experimental Study on Beneficiation of Fluorite Ore by Cyclonic-static Micro-bubble Flotation Column", Metal Mine, Vol. 26, pp. 48-49

Zhou, X. H., Song, X. J., Liu, J. T., Cao, Y. J., Zhang, M. Q., and Zhang, M., 2005, "Experimental study on fluorite mine by cyclonic-static micro-bubble flotation column", Mining and Metallurgy, Vol. 14, pp. 21-24

Zhou, Z. A., Xu, Z. H., Finch, J. A., Hu. H., and Rao, S. R., 1997, "Role of hydrodynamic cavitation in fine particle flotation", International Journal of Mineral Processing, Vol. 51, pp. 139-149 
APPENDICES 
Table A-1 Results of first stage of experiments

\begin{tabular}{|c|c|c|c|c|c|c|c|c|c|c|c|}
\hline $\begin{array}{l}\text { Exp. } \\
\text { No. }\end{array}$ & $\begin{array}{c}\text { Solid } \\
\text { Concentration } \\
\end{array}$ & $\begin{array}{c}\text { Collector } \\
\text { Dosage, } \\
\mathrm{kg} / \mathrm{mt}\end{array}$ & $\begin{array}{c}\text { Frother } \\
\text { Dosage, } \\
\mathrm{kg} / \mathrm{mt}\end{array}$ & $\begin{array}{l}\text { Feed } \\
\text { Rate, } \\
\mathrm{cm} / \mathrm{s}\end{array}$ & $\begin{array}{c}\text { Wash } \\
\text { Water, } \\
\mathrm{cm} / \mathrm{s}\end{array}$ & $\begin{array}{c}\text { Air Flow } \\
\text { Rate, } \mathrm{cm} / \mathrm{s}\end{array}$ & $\begin{array}{c}\text { Clean } \\
\text { Coal } \\
\text { Ash, \% } \\
\end{array}$ & $\begin{array}{l}\text { Tailings } \\
\text { Ash, \% }\end{array}$ & $\begin{array}{c}\text { Clean } \\
\text { Coal } \\
\text { Yield, \% }\end{array}$ & $\begin{array}{l}\text { Tailings } \\
\text { Yield, } \% \\
\end{array}$ & CMR, \% \\
\hline 1 & $10 \%$ & 0.3 & 0.08 & 0.53 & 0.092 & 0.375 & 20.75 & 28.94 & 71.26 & 28.74 & 73.45 \\
\hline 2 & $6 \%$ & 0.3 & 0.05 & 0.53 & 0.138 & 1.125 & 17.59 & 40.65 & 76.09 & 23.91 & 81.55 \\
\hline 3 & $3 \%$ & 0.3 & 0.12 & 0.43 & 0.138 & 0.75 & 16.88 & 81.78 & 90.41 & 9.59 & 97.73 \\
\hline 4 & $3 \%$ & 0.6 & 0.08 & 0.33 & 0.092 & 1.125 & 14.26 & 60.77 & 80.99 & 19.01 & 90.30 \\
\hline 5 & $6 \%$ & 0.3 & 0.08 & 0.53 & 0.046 & 0.75 & 16.71 & 52.89 & 82.33 & 17.67 & 89.17 \\
\hline 6 & $3 \%$ & 0.3 & 0.05 & 0.43 & 0.092 & 1.125 & 18.48 & 85.49 & 93.10 & 6.90 & 98.70 \\
\hline 7 & $6 \%$ & 1 & 0.12 & 0.53 & 0.138 & 0.375 & 16.95 & 43.22 & 76.58 & 23.42 & 82.70 \\
\hline 8 & $10 \%$ & 0.6 & 0.12 & 0.53 & 0.092 & 0.75 & 18.41 & 31.59 & 64.39 & 35.61 & 68.32 \\
\hline 9 & $6 \%$ & 0.6 & 0.12 & 0.33 & 0.046 & 1.125 & 13.33 & 59.89 & 79.01 & 20.99 & 89.05 \\
\hline 10 & $6 \%$ & 1 & 0.05 & 0.43 & 0.092 & 0.75 & 13.20 & 38.66 & 61.10 & 38.90 & 68.97 \\
\hline 11 & $3 \%$ & 1 & 0.12 & 0.53 & 0.092 & 1.125 & 20.38 & 81.37 & 95.53 & 4.47 & 98.92 \\
\hline 12 & $10 \%$ & 1 & 0.05 & 0.53 & 0.046 & 1.125 & 19.49 & 26.21 & 46.23 & 53.77 & 48.40 \\
\hline 13 & $3 \%$ & 0.3 & 0.05 & 0.33 & 0.046 & 0.375 & 14.58 & 69.35 & 84.44 & 15.56 & 93.80 \\
\hline 14 & $3 \%$ & 1 & 0.08 & 0.33 & 0.138 & 0.75 & 20.11 & 84.03 & 95.32 & 4.68 & 99.03 \\
\hline 15 & $3 \%$ & 1 & 0.12 & 0.43 & 0.046 & 0.375 & 21.19 & 84.72 & 96.99 & 3.01 & 99.40 \\
\hline 16 & $10 \%$ & 0.3 & 0.08 & 0.43 & 0.138 & 1.125 & 17.30 & 28.15 & 46.51 & 53.49 & 50.02 \\
\hline 17 & $3 \%$ & 0.6 & 0.08 & 0.53 & 0.138 & 0.375 & 15.30 & 68.55 & 85.35 & 14.65 & 94.01 \\
\hline 18 & $10 \%$ & 0.3 & 0.12 & 0.33 & 0.046 & 0.75 & 15.98 & 33.83 & 60.09 & 39.91 & 65.66 \\
\hline 19 & $10 \%$ & 1 & 0.08 & 0.43 & 0.046 & 1.125 & 19.93 & 25.68 & 44.81 & 55.19 & 46.66 \\
\hline
\end{tabular}




\begin{tabular}{|c|c|c|c|c|c|c|c|c|c|c|c|}
\hline 20 & $6 \%$ & 0.6 & 0.08 & 0.43 & 0.046 & 0.75 & 18.69 & 31.64 & 65.92 & 34.08 & 69.70 \\
\hline 21 & $3 \%$ & 0.6 & 0.05 & 0.53 & 0.046 & 0.75 & 17.21 & 74.06 & 89.63 & 10.37 & 96.50 \\
\hline 22 & $6 \%$ & 1 & 0.08 & 0.33 & 0.092 & 0.375 & 15.99 & 37.21 & 66.48 & 33.52 & 72.63 \\
\hline 23 & $10 \%$ & 0.6 & 0.05 & 0.43 & 0.138 & 0.375 & 19.01 & 25.69 & 38.72 & 61.28 & 40.78 \\
\hline 24 & $10 \%$ & 1 & 0.05 & 0.33 & 0.138 & 0.75 & 20.01 & 27.52 & 58.81 & 41.19 & 61.18 \\
\hline
\end{tabular}


Table A-2 Results of the second stage design of experiments

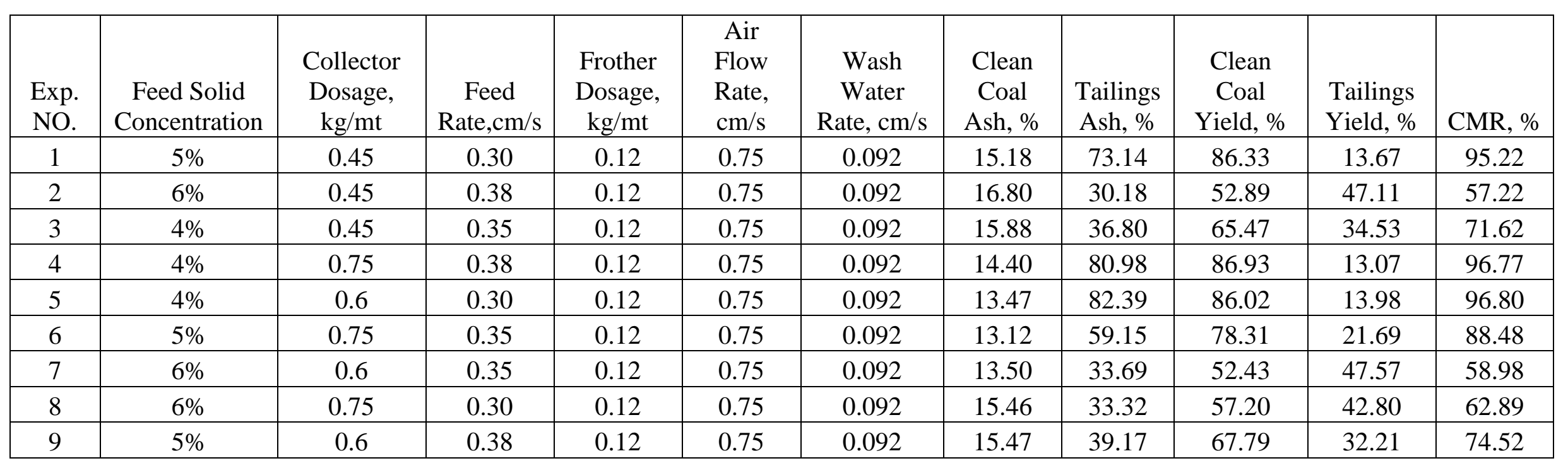


Table A-3 Results of the third stage of experiments

\begin{tabular}{|c|c|c|c|c|c|c|c|c|c|c|c|}
\hline $\begin{array}{l}\text { Exp. } \\
\text { No. }\end{array}$ & $\begin{array}{c}\text { Collector } \\
\text { Dosage, } \\
\mathrm{kg} / \mathrm{mt} \\
\end{array}$ & $\begin{array}{l}\text { Feed } \\
\text { Rate, } \\
\mathrm{cm} / \mathrm{s}\end{array}$ & $\begin{array}{c}\text { Frother } \\
\text { Dosage, } \\
\mathrm{kg} / \mathrm{mt}\end{array}$ & $\begin{array}{c}\text { Air Flow } \\
\text { Rate, } \mathrm{cm} / \mathrm{s}\end{array}$ & $\begin{array}{c}\text { Wash } \\
\text { Water, } \\
\mathrm{cm} / \mathrm{s}\end{array}$ & $\begin{array}{c}\text { Feed Solid } \\
\text { Concentration } \\
\end{array}$ & $\begin{array}{c}\text { Clean } \\
\text { Coal } \\
\text { Ash, } \% \\
\end{array}$ & $\begin{array}{l}\text { Tailings } \\
\text { Ash, \% }\end{array}$ & $\begin{array}{c}\text { Clean } \\
\text { Coal } \\
\text { Yield, \% } \\
\end{array}$ & $\begin{array}{l}\text { Tailings } \\
\text { Yield, \% } \\
\end{array}$ & CMR, \% \\
\hline 1 & 0.75 & 0.35 & 0.12 & 0.75 & 0.092 & $4 \%$ & 14.7 & 82.93 & 87.68 & 12.32 & 97.27 \\
\hline 2 & 0.8 & 0.35 & 0.12 & 0.75 & 0.092 & $4 \%$ & 14.23 & 89.51 & 88.21 & 11.79 & 98.39 \\
\hline 3 & 0.85 & 0.35 & 0.12 & 0.75 & 0.092 & $4 \%$ & 13.13 & 83.13 & 85.75 & 14.25 & 96.87 \\
\hline 4 & 0.9 & 0.35 & 0.12 & 0.75 & 0.092 & $4 \%$ & 14.48 & 49.07 & 75.07 & 24.93 & 83.49 \\
\hline
\end{tabular}


Column Flotation of Subbituminous Coal Using the Blend of Trimethyl Pentanediol Derivatives and Pico-Nano Bubbles

\author{
Jinxiang Chen
}

Thesis submitted to

the Benjamin M. Statler College of Engineering and Mineral Resources at West Virginia University in Partial Fulfillment of the Requirements for the Degree of

\author{
Master of Science \\ In \\ Mining Engineering \\ Department of Mining Engineering
}

APPROVAL OF THE EXAMING COMMITTEE

Roger Chen, Ph.D.

Yi. Luo, Ph.D.

Date

Felicia F. Peng, Ph.D., Chair 


\section{VITA}

Jinxiang Chen was born in October 21, 1988 in Chenzhou City, Hunan Province, People's Republic of China He graduated from Chenzhou No.2 High School in July 2007 and obtained his Bachelor's degree in Mineral Processing Engineering from China University of Mining and Technology (Beijing) in July 2011.

He joined the program of Master of Science in Mining Engineering Department of West Virginia University, U.S.A. in the fall of 2011. Now he is the candidate of M.S. degree in Mining Engineering.

Jinxiang Chen 